OLGA KAZUKO IWAI

“MAPEAMENTO DO USO DO SOLO URBANO DO MUNICÍPIO DE SÃO BERNARDO DO CAMPO, ATRAVÉS DE IMAGENS DE SATÉLITES”.

Dissertação apresentada à Escola Politécnica da Universidade de São Paulo para a obtenção do título de Mestre em Engenharia. 
OLGA KAZUKO IWAI

\section{"MAPEAMENTO DO USO DO SOLO URBANO DO MUNICÍPIO DE SÃO BERNARDO DO CAMPO, ATRAVÉS DE IMAGENS DE SATÉLITES”.}

Dissertação apresentada à Escola Politécnica da Universidade de São Paulo para a obtenção do título de Mestre em Engenharia.

Área de concentração:

Engenharia de Transportes

Orientador:

Prof. Dr. José Alberto Quintanilha.

SÃO PAULO

2003 
Este exemplar foi revisado e alterado em relação à versão original, sob responsabilidade única do autor e com a anuência de seu orientador.

São Paulo, 11 de julho de 2003.

Assinatura do autor

Assinatura do orientador

FICHA CATALOGRÁFICA

1 IWAI, OLGA KAZUKO

Mapeamento do uso do solo urbano do município de São

Bernardo do Campo, através de imagens de satélite / Olga

Kazuko Iwai. - ed.rev. - São Paulo, 2003.

$127 \mathrm{p}$.

Dissertação (Mestrado) - Escola Politécnica da

Universidade de São Paulo. Departamento de Engenharia de Transportes.

1. Sensoriamento remoto 2. Processamento digital de imagens 3. Planejamento territorial urbano I. Universidade de São Paulo. Escola Politécnica. Departamento de Engenharia de Transportes II. t. 
Aos meus pais Sadiko (in memorian) e Kunitika por todo o amor e carinho. Às minhas irmãs Márcia e Margarete pelo apoio e amizade. Ao meu marido Akira pela paciência e compreensão. 


\section{AGRADECIMENTOS}

Primeiramente a Deus, que tornou tudo isso possível.

Agradeço sinceramente a todos que me ajudaram, direta ou indiretamente, na realização deste trabalho, em especial:

Ao meu orientador Prof. Dr. José Alberto Quintanilha, pela orientação competente e segura, pela confiança depositada e pelo incentivo.

Aos professores Marcos Rodrigues e Homero Fonseca, pelo apoio e estímulo.

À professora Diana Sarita Hamburger, pela especial ajuda em todas as etapas do projeto, pelas correções e sugestões.

À prefeitura do Município de São Bernardo do Campo, em especial aos técnicos do Departamento de Planejamento Estratégico: Marcos Tatiyama, Patrícia Lotto, Ida Simões, Ronald Moreira, Roseli Yamabuchi, ao Sr. Humberto Pullin e à Sra. Iolene Marques da Silva Cordeiro.

Ao CNPq, pela ajuda financeira.

Aos colegas de pós-graduação do Laboratório de Geoprocessamento em especial à Rosangela Silva.

Ao pessoal da secretaria de graduação e pós-graduação do Departamento de Engenharia de Transportes: Simone, Conceição, Flávio, Cidinha e Edson. 


\section{SUMÁRIO}

\section{DEDICATÓRIA}

AGRADECIMENTOS

LISTA DE TABELAS

LISTA DE FIGURAS

RESUMO

ABSTRACT

1 INTRODUÇÃ

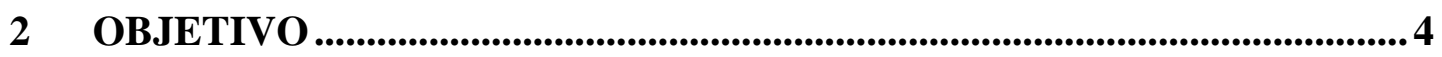

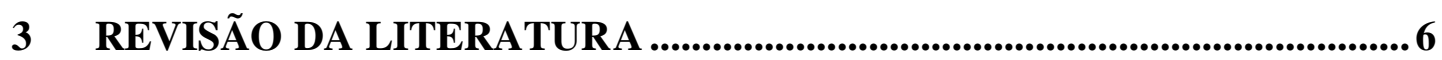

3.1 CONCEITOS E ASPECTOS TEÓRICOS DO SENSORIAMENTO REMOTO.................6

3.2 COMPORTAMENTO ESPECTRAL ........................................................... 9

3.3 RESOLUÇÃO EM SENSORIAMENTO REMOTO ............................................... 10

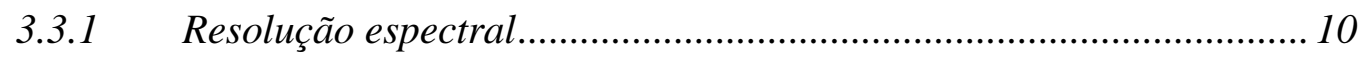

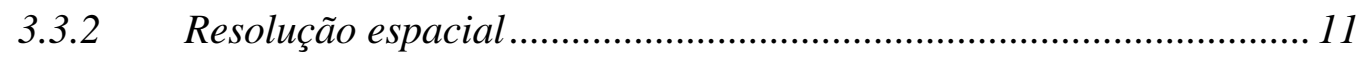

3.3.3 Resolução radiométrica ................................................................. 12

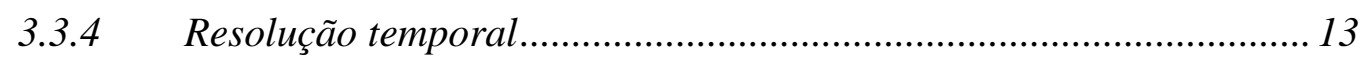

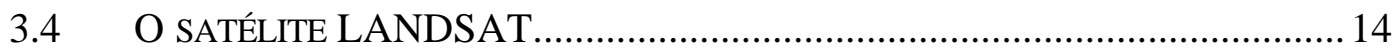

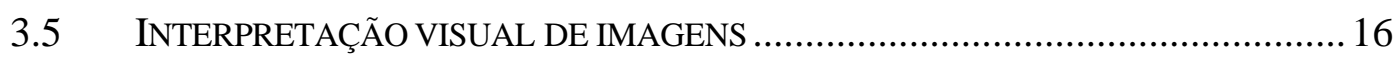

3.6 TÉCNICAS DE PROCESSAMENTO DIGITAL DE IMAGENS ................................ 18

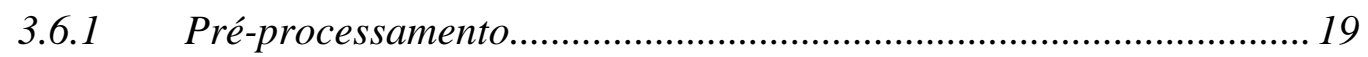

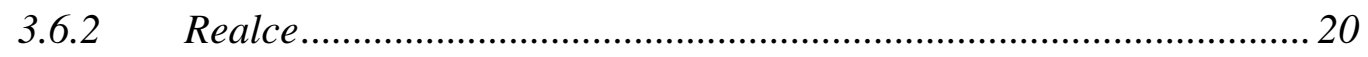

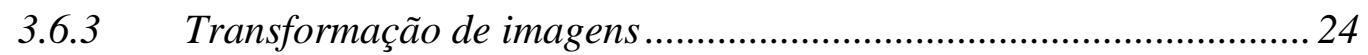

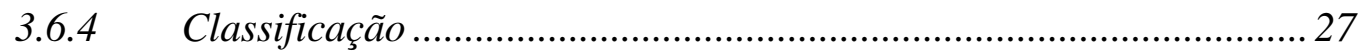

3.7 SENSORIAMENTO REMOTO EM ÁREAS URBANAS......................................... 35

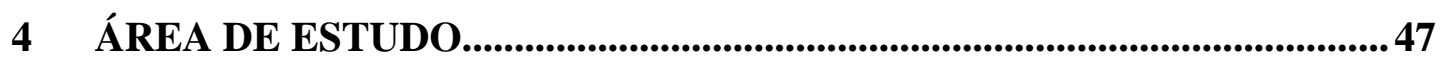

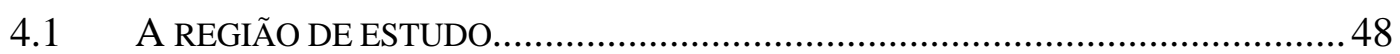

4.2 PROCESSO DE URBANIZAÇÃO DA REGIÃO DE ESTUDO ..................................50

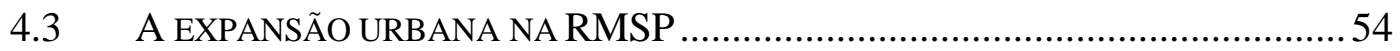




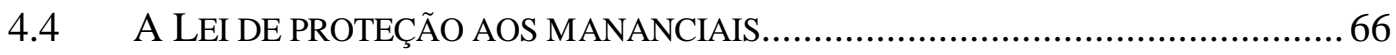

5 MATERIAIS E MÉTODOS ............................................................................. 77

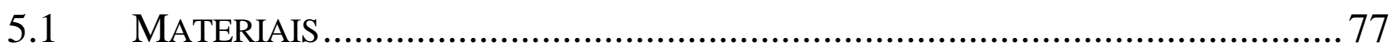

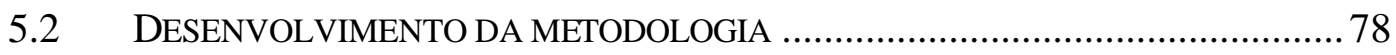

5.2.1 Pré-processamento/ correção geométrica ........................................ 80

5.2.2 Definição das classes de uso do solo/ legenda. ................................. 81

5.2.3 Análise das características espectrais das classes. .......................... 88

5.2.4 Amostras a serem analisadas....................................................... 89

6 APLICAÇÃO DAS TÉCNICAS DE CLASSIFICAÇÃO ............................95

7 ANÁLISE DOS RESULTADOS DA CLASSIFICAÇÃO............................ 112

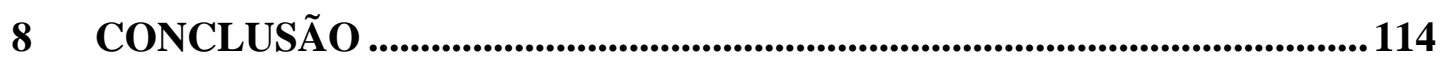

9 REFERÊNCIAS BIBLIOGRÁFICAS ................................................................. 116 


\section{LISTA DE TABELAS}

Tabela 1 - Características orbitais do satélite LANDSAT 7.......................... 13

Tabela 2 - Programa LANDSAT. ….............................................................. 14

Tabela 3 - Características do sensor ETM+ (Enhanced Thematic Mapper Plus) do satélite LANDSAT 7. .................................................................... 14

Tabela 4 - Características espectrais do sensor TM do satélite LANDSAT 5 e principais aplicações........................................................................ 15

Tabela 5 - Comportamento espectral da vegetação ......................................... 26

Tabela 6 - Qualidade da classificação associada aos valores da estatística

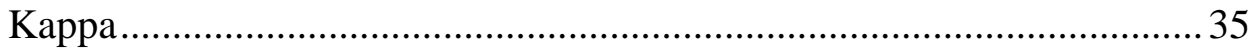

Tabela 7 - População urbana e rural no Brasil (1950-2000) (milhares) ........... 51

Tabela 8 - População residentes nas principais regiões metropolitanas brasileiras 52

Tabela 9 - População residente e taxas de crescimento anual (1980-2000) ..... 54

Tabela 10 - Taxa de crescimento anual da população residente (\%) .55

Tabela 11 - Crescimento da população e dos domicílios permanentes ocupados no Município de São Paulo (1980-1991)

Tabela 12 - Crescimento vegetativo e migratório no município de São Bernardo do Campo

Tabela 13 - Área dos municípios da região da Bacia Billings, densidade demográfica e variação da densidade demográfica no período 1980/1996.

Tabela 14 - Expansão de área urbanizada e superfície de loteamentos aprovados em áreas de mananciais para alguns municípios (1974-1980).63

Tabela 15 - Densidades habitacionais em favelas na Bacia Billings (1996) .... 63 Tabela 16 - Acréscimo Populacional 91/96, na Bacia Billings, por municípios. 
Tabela 17 - Crescimento da população residente na Bacia, por município, no

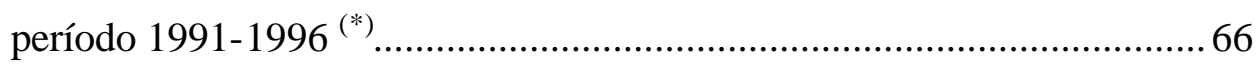

Tabela 18 - Análise dos níveis de cinza das bandas da imagem LANDSAT 7.

Tabela 19 - Resultado da classificação 1 ..................................................... 105

Tabela 20 - Resultados da classificação 2 .................................................. 107

Tabela 21 - Resultados da classificação 3 .................................................. 109

Tabela 22 - Resumo dos resultados ......................................................... 111 


\section{LISTA DE FIGURAS}

Figura 1- Mecanismos de interações ........................................................... 6

Figura 2 -Espectro eletromagnético.......................................................... 7

Figura 3- Comportamento espectral de alguns alvos terrestres ........................ 9

Figura 4 - Esquema da resolução espacial dos principais sistemas sensores... 12

Figura 5 - Histograma com aumento linear de contraste (ALC) ..................... 23

Figura 6 - Função de transferência para o fatiamento de níveis de intensidade.

Figura 7 - Comportamento espectral da vegetação ....................................... 25

Figura 8 - Classificação supervisionada, método do paralelepípedo................ 30

Figura 9 - Classificação supervisionada, método da distância mínima. ........... 30

Figura 10 - Classificação supervisionada, máxima verossimilhança............... 31

Figura 11 - Brasil, América do Sul / Estado de São Paulo, Região Metropolitana de São Paulo / Região Metropolitana de São Paulo, São Bernardo do Campo. .48

Figura 12 - Imagem LANDSAT7 ETM+, composição colorida 3B4G5R, setembro 1999, órbita ponto 219-076, 219-077

Figura 13 - Taxa geométrica de crescimento anual da população residente.... 52

Figura 14 - Taxa geométrica de crescimento anual da população residente .... 55

Figura 15 - Taxa geométrica de crescimento anual ...................................... 61

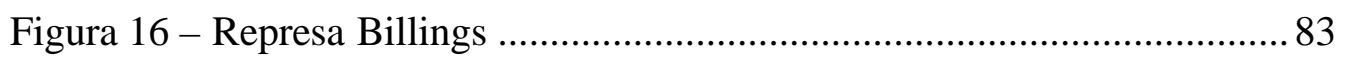

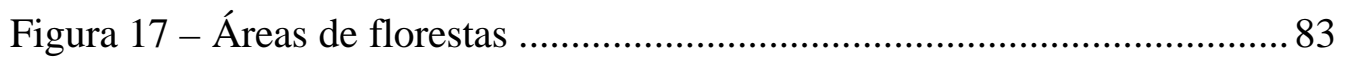

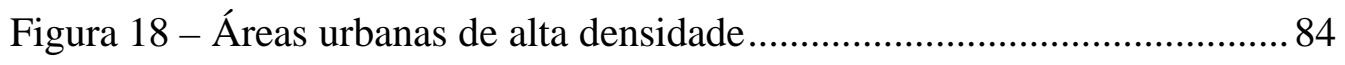

Figura 19 - Áreas urbanas de média densidade.............................................. 85

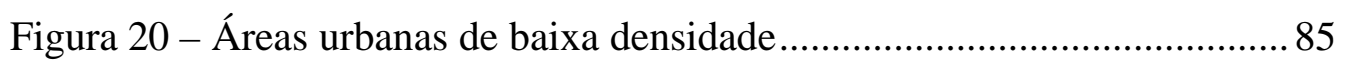

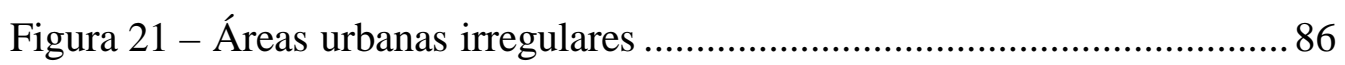


Figura 22 - Áreas multifamiliares

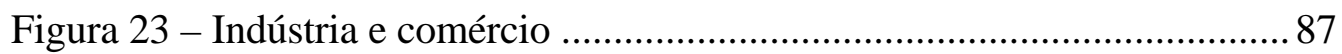

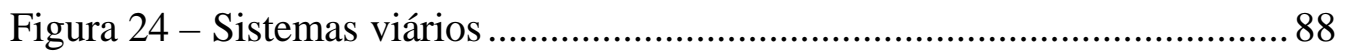

Figura 25 - Localização das amostras das classes analisadas na composição colorida 3B4G5R.

Figura 26 - Bandas 7 e 5 com realce linear com saturação, respectivamente. . 92

Figura 27 - Histograma das amostras da classe vegetação. .93

Figura 28 - Histograma da amostra de água .93

Figura 29 - Geração de níveis de cinza das classes a partir das amostras. ....... 94

Figura 30 - Classificação 1 .97

Figura 31 - Recorte ampliado da classificação 1 .98

Figura 32 - Classificação 2 99

Figura 33 - Recorte ampliado da classificação 2 100

Figura 34 - Classificação 3. 102

Figura 35 - Ampliação da classificação 3 103 


\section{RESUMO}

O crescimento urbano nos grandes centros de desenvolvimento do Brasil, geralmente ocorre sem um planejamento integrado e sem visar o crescimento populacional futuro. Áreas que deveriam ser protegidas como as áreas de mananciais ou de risco (áreas muito íngremes ou sujeitas às inundações) acabam sendo ocupadas de maneira irregular, colocando em risco a população e o meio ambiente. $\mathrm{O}$ monitoramento e fiscalização destas ocupações são realizados de maneira demorada e ineficiente, pois faltam equipamentos e pessoas capacitadas para a realização deste trabalho. Visando entender e incorporar as novas tecnologias existentes, a Prefeitura do Município de São Bernardo do Campo em conjunto com o Laboratório de Geoprocessamento do Departamento de Engenharia de Transportes da Escola Politécnica de Universidade de São Paulo desenvolveram uma metodologia de mapeamento do uso do solo urbano através de técnicas de sensoriamento remoto e processamento digital de imagens. Através destas técnicas, as classes de uso do solo que melhor caracterizam a região foram selecionadas, definindo-se assim uma legenda de classes de uso do solo que permite o mapeamento da cidade. Com o mapeamento da cidade é possível a detecção das regiões mais críticas ao crescimento urbano e o seu direcionamento para regiões mais adequadas. Esta metodologia, integrada com outras técnicas de planejamento já existentes fornece subsídios a um melhor planejamento urbano da cidade. Esta dissertação se baseia na experiência deste projeto, enfatizando os aspectos teóricos das técnicas de processamento digital de imagens de satélite aplicadas nesta experiência e os problemas urbanos e ambientais da região. Através da metodologia desenvolvida e do mapeamento da cidade, foi possível uma percepção global da distribuição dos diversos usos do solo da região (indústria, comércio, residenciais) e a localização das áreas críticas ao crescimento urbano (áreas de proteção e de florestas), mostrando que as imagens de satélite são um bom instrumento no auxílio ao planejamento urbano. 


\begin{abstract}
The urban growth in the development centers of the Brazil, generally occurs without an integrated planning and without aiming at the future population growth. Areas that would have been protected as water sources areas or at risk (mount hillside or subject to flooding areas) have been ocuppied in a irregular way, placing in risk the population and the environment. The monitoring and fiscalization of these occupations are carried in delayed and inefficient way, because of the lack of equipment and people enabled to accomplishment this work. Aiming at to understand and to incorporate the new existing technologies, the City Hall of the São Bernardo do Campo with partnership with the Geoprocessing Laboratory of the Transportation Department of the Polytechnical School of the University of São Paulo had developed a methodology of urban land use mapping through the use of remote sensing and digital image processing techniques. Through these techniques, the land use classes that better characterize the region had been selected, defining thus, the land use legend that allows the mapping of the city. With this mapping it is possible the identification of the most critical regions of the city and its orientation to more appropriated regions. This methodology, integrated with others already existing planning techniques, provides aid to improve the urban planning of the city. The experience of this project is the base of this dissertation, that emphasized the theoretical aspects of the digital image processing techniques applied in this experience and the urban and environmental problems of the region.

Through the methodology developed and with the mapping of the city, it was possible a global perception of the diverse land uses distribution of the region (industry, commerce, residential) and the localization of the critical areas to the urban growth (protection areas and forests), showing that the satellite images are a good instrument in the aid of the urban planning.
\end{abstract}




\section{INTRODUÇÃO}

As formas de ocupação das áreas urbanas e sua dinâmica ao longo do tempo são informações que o poder público necessita para que as demandas da população e da cidade sejam previstas de forma a supri-las com eficiência e rapidez.

O crescimento populacional elevado em algumas regiões do país, ocasionado pelo crescimento econômico destas regiões e a falta de planejamento, trouxe como consequiência uma ocupação desordenada dos territórios. A tarefa de monitoramento das formas de ocupação do uso do solo é muito complexa.

Durante muitos anos, fatores históricos, culturais, investimentos e iniciativas governamentais, transformaram a região sudeste do Brasil, num grande pólo de atração de empregos. O intenso fuxo migratório para a região, atraídos pelas ofertas de emprego, ocasionou um crescimento populacional intenso. O crescimento urbano acelerado da região, associado à falta de planejamento e infra-estrutura, trouxe como consequiência escassez dos territórios para implantação de novas indústrias, esgotamento dos recursos naturais, poluição das águas, alta dos preços dos terrenos, congestionamentos e queda na qualidade de vida da população.

A população de baixa renda é cada vez mais afastada dos grandes centros urbanos (alta dos preços dos aluguéis, escassez de áreas para construção de moradias). A procura por espaços para construção de moradias leva este contingente populacional às regiões periféricas da cidade ou àquelas de difícil construção, abandonadas pela especulação imobiliária, como as encostas íngremes dos morros ou as áreas protegidas dos mananciais.

As ocupações desordenadas destas áreas e métodos de construção precários trouxeram como consequiências diversos riscos à população, como o desmoronamento de encostas, e diversos efeitos ambientais, como a poluição das águas dos rios e mananciais e desmatamento de florestas, erosão, assoreamento dos rios, enchentes, etc.

Para que o poder público tenha algum controle da situação ele necessita de ferramentas para a fiscalização destas áreas de modo que novas invasões sejam evitadas. As grandes extensões territoriais, a dificuldade de acesso e a falta de 
equipamentos e pessoal treinado impedem que a fiscalização seja feita de maneira rigorosa. A invasão das terras se dá de forma muito rápida e o poder público se torna incapaz de evitar essa situação.

Para que a situação não se agrave ainda mais, os municípios procuram formas alternativas de monitoramento e fiscalização. Uma das ferramentas encontradas no auxílio destas tarefas é a utilização de imagens de satélite. As imagens de satélite se mostraram eficazes para a solução de diversos problemas, pois abrangem áreas extensas, fornecendo informações atualizadas periodicamente, tornando-se um grande auxílio para o monitoramento e fiscalização de áreas extensas e de difícil acesso.

A Prefeitura do Município de São Bernardo do Campo procurando formas alternativas de monitoramento e fiscalização de suas áreas ocupadas, em convênio com o Laboratório de Geoprocessamento do Departamento de Engenharia de Transportes da Universidade de São Paulo, desenvolveu uma metodologia de monitoramento do uso do solo através de imagens de satélite de sensoriamento remoto orbital de forma a realizar um monitoramento constante da região de forma rápida, com um custo relativamente baixo e sem o deslocamento de grande contingente humano para fiscalização nestes locais.

A presente dissertação, vinculada a essa experiência, descreve detalhadamente a parte metodológica estudada e desenvolvida para o projeto citado.

O texto que se segue está estruturado da seguinte forma:

Capítulo 1: Introdução. Na introdução estão descritas as circunstâncias que levaram ao desenvolvimento do projeto, o contexto geral do assunto.

Capítulo 2: Objetivo. O objetivo da dissertação e as etapas necessárias para atingir ao objetivo proposto estão descritos neste capítulo.

Capítulo 3: Revisão Bibliográfica. Na revisão bibliográfica foram abordados os aspectos teóricos do sensoriamento remoto como o espectro eletromagnético, o comportamento espectral dos alvos terrestres, os tipos de resoluções existentes, a definição de imagens digitais, o satélite LANDSAT 7, o sensor ETM+ do satélite LANDSAT 7, as técnicas de processamento digital de imagens e uma revisão dos 
trabalhos que foram realizados sobre sensoriamento remoto em áreas urbanas. Neste capítulo foi realizada uma revisão dos trabalhos desenvolvidos por diversos autores em áreas urbanas através de diversos sensores e algoritmos de classificação como a utilização de redes neurais, classificação fuzzy, a utilização de texturas, etc. Várias destas técnicas porém, não foram utilizadas no trabalho, apenas foram citadas para mostrar como as diversas técnicas estão sendo trabalhadas nos estudos urbanos e os resultados alcançados por estes autores.

Capítulo 4: Área de estudo, o crescimento populacional, a forma como expansão urbana ocorreu e os problemas ambientais da região de estudo foram descritos neste capítulo. Problemas complexos que envolvem vários municípios podem ser solucionados através de planejamentos integrados como o Consórcio Intermunicipal de Planejamento Integrado. Este consórcio foi colocado neste capítulo apenas como um exemplo de ação que está sendo realizada atualmente na região.

Capítulo 5: Materiais e métodos. Neste capítulo foram descritos os materiais utilizados, as etapas, a seqüência e a forma como as técnicas de processamento digital de imagens foram utilizadas para o desenvolvimento da metodologia.

Capítulo 6: Aplicação das técnicas de classificação. O capítulo mostra as diversas etapas do processo de classificação de imagens e as escolhas das classes utilizadas no processo.

Capítulo 7: Análise dos resultados da classificação. Os resultados obtidos nas etapas anterior foram analisados neste capítulo. Foram analisados também os problemas encontrados em cada classe de uso do solo e os índices Kappa e as matrizes de erros de omissão e comissão resultantes das classificações realizadas.

Capítulo 8: Conclusão. As conclusões referentes ao desenvolvimento da metodologia foram apresentadas neste capítulo.

Capítulo 9: Referências Bibliográficas. Relação das bibliografias estudadas para o desenvolvimento dos estudos. 


\section{OBJETIVO}

As imagens de satélite como ferramenta para monitoramento do uso do solo mostram-se como uma alternativa viável e de custo relativamente baixo. Os sensores dos satélites são capazes de captar constantemente, as imagens da Terra, sem a necessidade de programação prévia, abrangendo extensas áreas e fornecendo informações atualizadas, que são extraídas através de técnicas de análise visual e de processamento digital das imagens.

O mapeamento das áreas urbanas permite levantar informações importantes a respeito do crescimento urbano, propiciando o planejamento urbano integrado e seu direcionamento para regiões de interesse.

A utilização de técnicas de sensoriamento remoto para estudos urbanos permite a obtenção de informações de forma rápida e constante. Os estudos urbanos, principalmente nas áreas metropolitanas, requerem uma permanente atualização e ordenação dos dados para subsidiar o planejamento territorial.

O principal objetivo desta dissertação é o desenvolvimento de uma metodologia para o mapeamento do uso do solo urbano, utilizando-se técnicas de processamento digital de imagens de sensoriamento remoto, já consagradas no meio científico. Para se alcançar esse objetivo foram realizadas as seguintes etapas:

- Escolha do melhor tipo de imagem;

- Escolhas das classes que melhor representam o município;

- Registro das imagens;

- Retirada das amostras representativas das classes escolhidas;

- Classificação das imagens;

A área escolhida para a realização dos estudos é a região do Município de São Bernardo do Campo. Esta região foi escolhida pela inexistência de estudos na linha de interesse deste projeto na área selecionada e por apresentar características específicas, como o processo rápido de crescimento urbano e a ocupação desordenada do espaço físico devido à falta de planejamento, o que provoca a invasão das áreas protegidas por lei (áreas de proteção aos mananciais, áreas de 
reserva florestal) e diversos problemas ambientais (poluição das águas e desmatamento das florestas). 


\section{REVISÃO DA LITERATURA}

\subsection{Conceitos e aspectos teóricos do sensoriamento remoto}

Segundo NOVO (1995), o sensoriamento remoto pode ser definido como sendo a utilização conjunta de modernos sensores, equipamentos para processamento de dados, equipamentos de transmissão de dados, aeronaves, espaçonaves, etc., com o objetivo de estudar o ambiente terrestre através do registro e da análise das interações entre a radiação eletromagnética e as substâncias componentes do planeta Terra em suas mais diversas manifestações.

Os sistemas sensores são equipamentos que coletam e convertem a energia eletromagnética proveniente dos objetos da superfície terrestre, em sinais passíveis de serem registrados, apresentando-a de forma adequada à extração de informações. No Sensoriamento Remoto, a principal fonte de energia utilizada é a radiação eletromagnética, sendo as principais fontes disponíveis o Sol e a própria Terra (Figura 1).

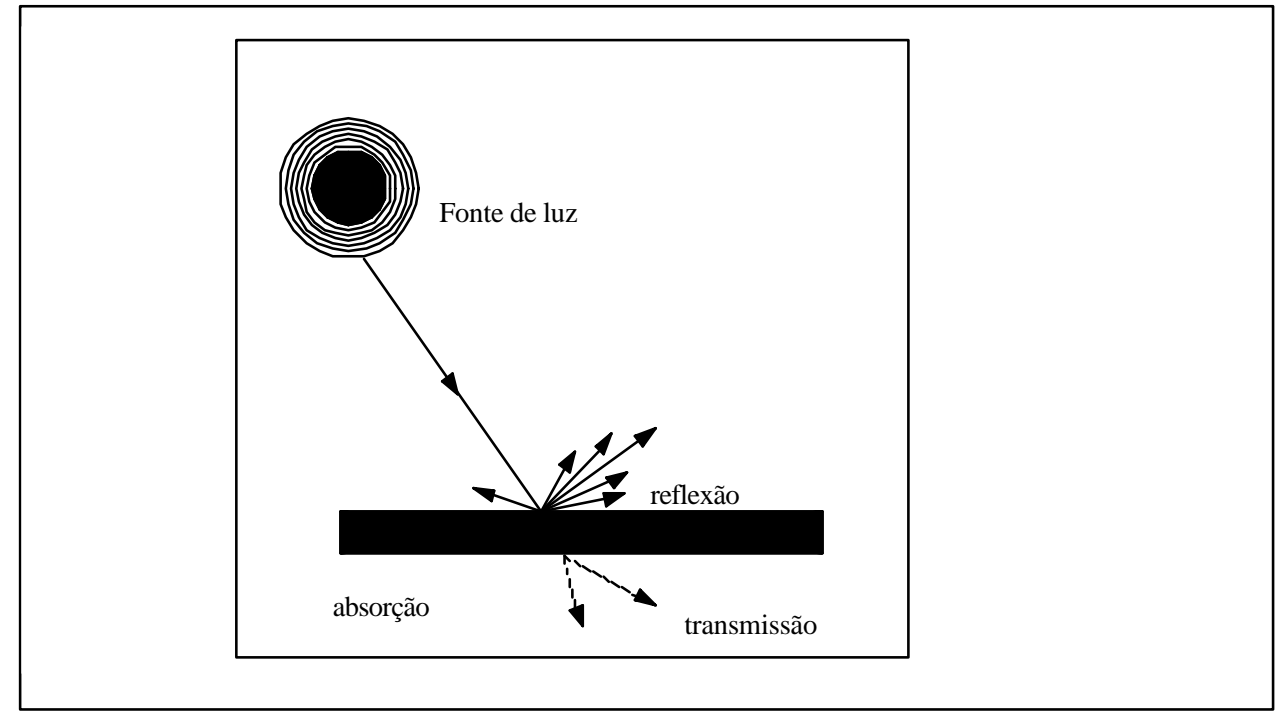

Figura 1- Mecanismos de interações

Fonte: EASTMAN (1998).

O espectro eletromagnético é a distribuição da radiação eletromagnética (gerada por ondas produzidas pela oscilação ou aceleração de uma carga elétrica) em um contínuo, que se estende desde ondas de frequiência extremamente alta (e 
comprimento de onda curto) até as ondas de freqüência extremamente baixa (e comprimento de onda longo) (Figura 2).

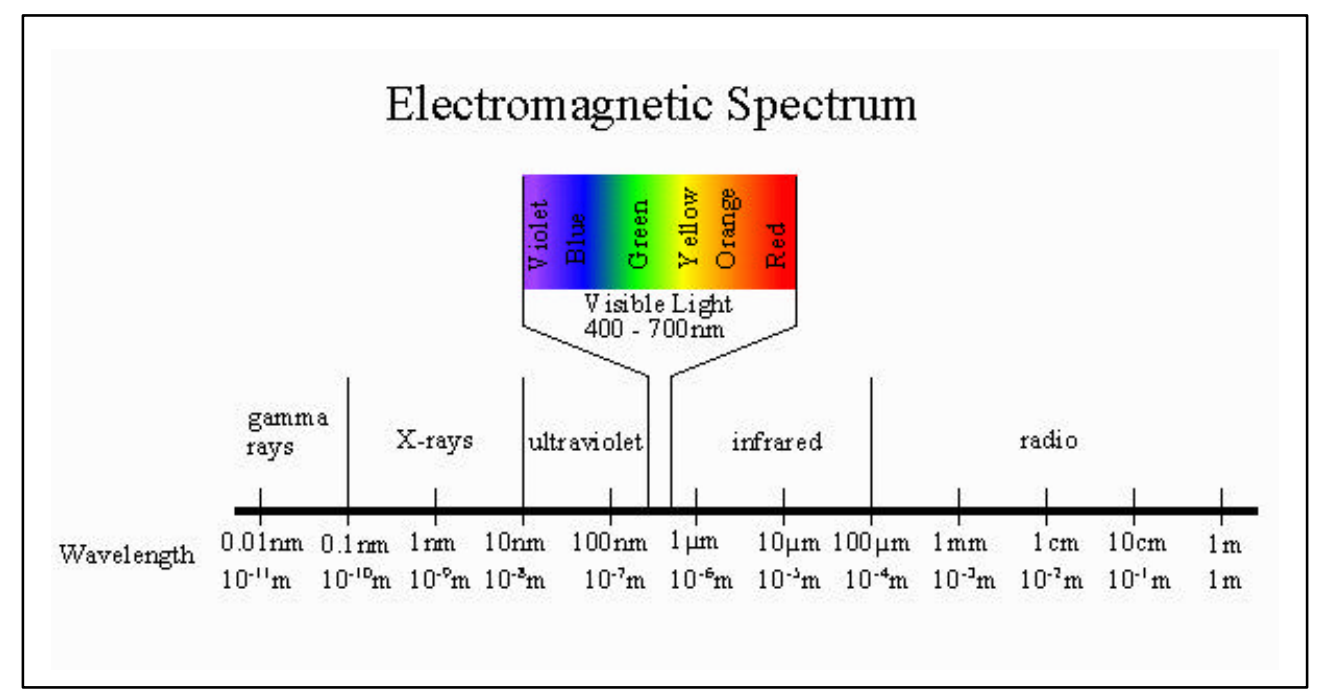

Figura 2 -Espectro eletromagnético.

Fonte: NOAA (2003).

O intervalo no qual o olho humano tem sensibilidade (visível) corresponde a uma faixa relativamente estreita do espectro eletromagnético (faixa de luz visível - 0,39 a 0,77 $\mu \mathrm{m}$ ) (IBGE, 2001). Os sensores dos satélites captam a radiação transmitida, emitida ou irradiada por um alvo e a registram em determinadas faixas do espectro eletromagnético.

A maior parte dos equipamentos sensores desenvolvidos operam nas seguintes regiões do espectro eletromagnético: visível, infravermelho e microondas. (IBGE, 2001)

Os sistemas sensores podem ser classificados de diferentes maneiras. Quanto à fonte de energia captada pelos sensores eles podem ser classificados em sensores passivos e sensores ativos.

Os sensores passivos detectam a radiação refletida ou emitida pelos objetos da superfície terrestre. Não possuem fonte própria de radiação, dependem, portanto, de uma fonte de radiação externa para que possam operar sendo o Sol a principal fonte da referida radiação. 
Os sensores ativos produzem sua própria fonte de energia. Em aplicações ambientais e de mapeamento o melhor exemplo é constituído pelo Radar. Os sistemas radares emitem energia na região do espectro eletromagnético das microondas.

A reflexão dessa energia pelos materiais na superfície da Terra é então medida para produzir uma imagem da área recoberta pelo sensor. Os sistemas radares oferecem algumas vantagens como ser utilizável à noite, pois independe da radiação solar e em regiões com cobertura de nuvens persistentes (os comprimentos de onda, nessa faixa do espectro, são pouco afetados por nuvens).

Os sistemas sensores podem também ser classificados em função da região do espectro em que operam e pelo tipo de energia que detectam. Os sensores que operam na região óptica do espectro, em função do tipo de energia que detectam, podem ser classificados como sensores termais e sensores de energia solar refletida. Os sensores que possuem sistemas de microondas são sensores ativos à base de ondas de radar que operam na faixa das microondas. Como não são afetados pela cobertura de nuvens e pelas condições atmosféricas, podem operar 24 horas por dia (IBGE, 2001).

A imagem digital (ou imagem discreta) resultante destes sensores é constituída por um arranjo de elementos (dígitos) sob a forma de malha ou grade regular. As unidades ou celular desta grade têm sua localização definida por um sistema de coordenadas " $\mathrm{x}$ " e "y", representadas por colunas e linhas, respectivamente. Por convenção, a origem da imagem é sempre no canto superior esquerdo.

$\mathrm{Na}$ imagem, o menor elemento da grade é chamado de pixel (contração de picture element). O pixel representa uma área da superfície da terra. A cada pixel está associado um valor numérico que indica a intensidade da radiação eletromagnética da área da superfície da terra correspondente ao pixel, por exemplo: intensidade de luz refletida ou calor emitido. Essa intensidade, denominada de Nível de Cinza NC- ou Digital Number -DN ou Pixel Value - PV-, é representada por tonalidades de cinza que variam do preto (nível mínimo) ao branco (nível máximo), sendo também referida como o brilho do pixel (IBGE, 2001).

Uma imagem digital pode ser definida por uma função bidimensional da intensidade de energia Eletromagnética refletida ou emitida pela área imageada, representada por 
um matriz I (x,y), onde os valores de I são resultantes da intensidade (brilho) dos materiais da área correspondente ao pixel de coordenadas (x,y). Essa intensidade é representada por um valor inteiro, não-negativo e finito, chamado nível de cinza.

\subsection{Comportamento espectral}

Para que as informações possam ser extraídas das imagens de satélite de sensoriamento remoto, primeiramente há a necessidade de se conhecer o comportamento espectral dos alvos terrestres. O comportamento espectral dos alvos representa como e quanto o alvo reflete ou emite da radiação espectro eletromagnética e é representado pela assinatura espectral que pode ser obtida através do gráfico das reflectâncias (razão entre o fluxo refletido e o fluxo incidente) dos alvos e os comprimentos de onda sobre os quais foram medidas estas refletâncias (Figura 3).

A Figura 3 exemplifica as assinaturas espectrais de alguns alvos, mostrando simultaneamente as faixas espectrais de operação do sensor TM-LANDSAT.

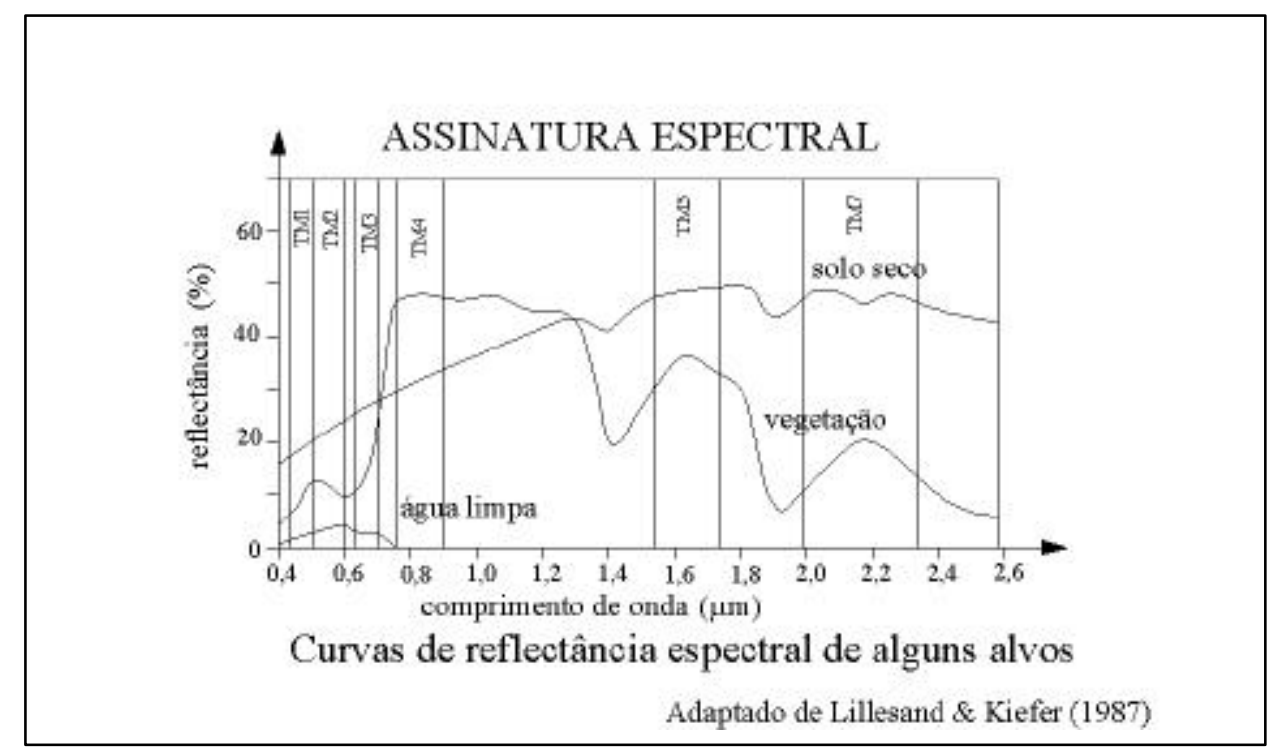

Figura 3- Comportamento espectral de alguns alvos terrestres

Fonte: Adaptado de LILLESAND \& KIEFER (1987).

Dos fatores que interferem na coleta dos dados, as interações atmosféricas são as de maior importância. As partículas e gases existentes na atmosfera dispersam os diferentes comprimentos de onda alterando as informações que são refletidas ou 
irradiadas pelos alvos na superfície terrestre. As partículas de água presentes nas nuvens "absorvem" e "espalham" os comprimentos de onda maiores de $300 \mathrm{~nm}$. Somente comprimentos de ondas maiores conseguem atravessar as nuvens sem que sejam espalhados, refletidos ou absorvidos, como na faixa das microondas.

O posicionamento solar é outro fator que interfere nos resultados de aquisição dos dados, aumentando ou diminuindo o valor da reflectância detectada pelo sensor.

O valor de reflectância que é captada pelo sensor é o resultado da energia que foi irradiada ou refletida não somente pelos alvos de interesse, mas por todos os alvos adjacentes a ele. A reflectância de um alvo, medida de maneiras diferentes (em laboratório, em campo ou através do satélite), apresenta resultados diferentes mostrando assim, que os fatores descritos acima interferem muito nos resultados finais.

\subsection{Resolução em sensoriamento remoto}

"Resolução é uma medida da habilidade que um sistema sensor possui de distinguir entre respostas que são semelhantes espectralmente ou próximas espacialmente" (SPRING, 2002). As resoluções podem ser classificadas em espacial, espectral, temporal e radiométrica.

\subsubsection{Resolução espectral}

Resolução espectral é a quantidade e a largura dos intervalos de comprimentos de onda do espectro eletromagnético medida pelo sistema sensor. Os sensores são sensíveis a determinados intervalos de comprimentos de onda ou bandas do espectro eletromagnético. Quanto maior o número de canais e mais estreitos os intervalos de comprimento de onda, melhor será a resolução espectral e mais precisas e completas serão as informações obtidas.

Alguns trabalhos realizados para áreas urbanas procuram as melhores bandas para os estudos nestas áreas. 
Segundo COSTA (1989), a utilização de imagens no período chuvoso para delimitação de áreas urbanas facilita a separação entre o urbano e o não-urbano, fornecendo bons resultados. A interpretação visual das bandas do sensor TM revelou que tanto no período seco quanto no período chuvoso, a banda três (vermelho) diferenciou as áreas urbanas e não urbanas com mais facilidade de que as demais bandas.

FORESTI (1978), utilizando sensor MSS, demonstra que a identificação e delimitação de áreas urbanas devem ser realizadas em imagens bem contrastadas, e que imagens em períodos chuvosos apresentam maior contraste entre os diferentes alvos.

\subsubsection{Resolução espacial}

Segundo IBGE (2001), cada sensor é projetado para fornecer dados a um determinado nível de detalhes espaciais. Quanto menor o objeto possível de ser identificado, maior o poder de resolução espacial. A resolução espacial pode ser definida como a habilidade que um sensor possui de distinguir objetos que são próximos espacialmente. A referência mais usada para a resolução espacial, é o tamanho do Elemento de Resolução no Terreno - ERT. O tamanho do ERT é definido pelo IFOV - Instantaneous Field of View - do sensor, que é a área do terreno "vista" pelo sensor em um dado instante. O IFOV nominal é medido pelo ângulo do sistema ótico ou pela distância equivalente no terreno).

Os satélites atualmente utilizados para os estudos urbanos apresentam resolução espacial que variam de valores de 30m no modo multiespectral (LANDSAT 7) a $1 \mathrm{~m}$ (modo pancromático no IKONOS II) (Figura 4).

Novos satélites como o Quick Bird produzem imagens com até $0,61 \mathrm{~m}$ de resolução espacial no modo pancromático (IMAGERY CENTRAL, 2003). 


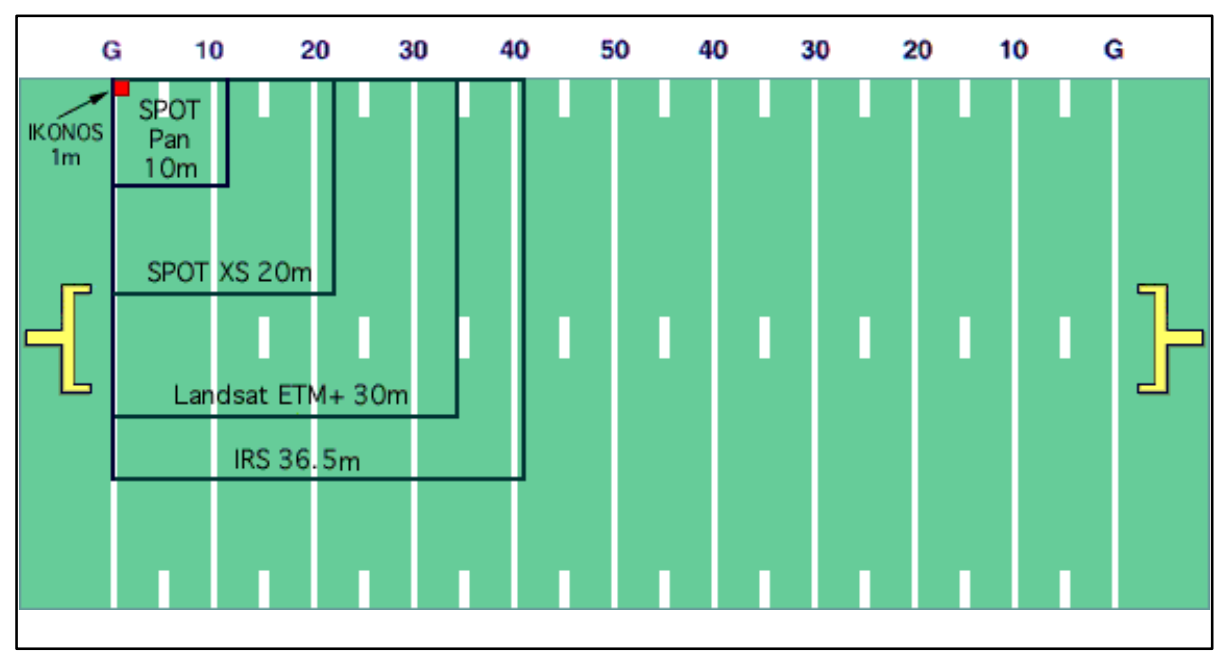

Figura 4 - Esquema da resolução espacial dos principais sistemas sensores.

Fonte: NASA (2001a).

As áreas urbanas apresentam concentração de pessoas, bens e capitais, e que ocupam o solo de diferentes formas e densidades.

Segundo MANSO et al. (1978), os espaços físicos homogêneos correspondem a agrupamentos humanos coerentes sócio-culturalmente. A comunidade urbana não é um agrupamento indefinido e indiferente, e nem uma reunião casual de pessoas e edifícios.

A relação sócio-econômica está muito ligada às características do loteamento. Em áreas onde o padrão sócio econômico é elevado, nota-se lotes maiores, baixa densidade, presença de áreas arborizadas, vias largas, e geralmente o material de construção dos telhados é a telha. Por outro lado, áreas de baixo padrão sócioeconômico a densidade ocupacional é elevada, não há espaçamento entre os lotes, ausência quase total de vegetação e áreas verdes e materiais de construção de telhados diversos. Geralmente não apresentam vias asfaltadas, são em geral de solo exposto e largura reduzida.

\subsubsection{Resolução radiométrica}

É dada pela sensibilidade dos sistemas sensores em distinguir os sinais de retorno da energia radiante que atinge $\mathrm{o}$ alvo. 
A energia radiante que atinge o sensor é registrada e transformada em valores digitais. Este valor depende do número de "bits" do meio de registro utilizado para armazenar a informação e depois transformada em sinal gráfico. A maioria dos sensores fornece imagens digitais com 8 bits de profundidade, ou seja, os valores digitais variam de 0 a 255 correspondendo a 256 tons de cinza. Hoje, existem satélites que fornecem até 12 bits (sensor TIR - Thermal Infrared do satélite ASTER

- Advanced Spaceborne Thermal Emission and Reflection Radiometer) de profundidade (ASTER, 2002).

\subsubsection{Resolução temporal}

Resolução temporal é a freqüência temporal com a qual uma determinada porção da superfície da Terra/cena/alvo será amostrada por determinado sensor.

O satélite LANDSAT 7 possui resolução temporal de 16 dias. Isso significa que o satélite sobrevoa a mesma região em intervalos de 16 dias (Tabela 1).

Para a realização de estudos temporais, os satélites apresentam uma grande vantagem. Por estarem constantemente imageando a superfície da Terra, não necessitam de programação prévia. As imagens imageadas são armazenadas, permitindo a recuperação de dados antigos (desde o lançamento do satélite) possibilitando diversos estudos de mudanças temporais e desenvolvimento do uso do solo.

Tabela 1 - Características orbitais do satélite LANDSAT 7.

\begin{tabular}{|c|c|}
\hline Altitude & $705 \mathrm{~km}$ \\
\hline Inclinação & $98.2^{\circ}$ \\
\hline Órbita & $\begin{array}{l}\text { polar, sol- } \\
\text { síncrona }\end{array}$ \\
\hline Quantização & 8 bits \\
\hline $\begin{array}{l}\text { Horário de cruzamento com o } \\
\text { equador }\end{array}$ & $\begin{array}{c}\text { 10:00 hs }+/-15 \\
\text { min }\end{array}$ \\
\hline Cobertura de repetição & $\begin{array}{l}16 \text { dias }(233 \\
\text { orbitas) }\end{array}$ \\
\hline Capacidade de armazenamento & $375 \mathrm{~Gb}$ \\
\hline Data de lançamento & Abril/99 \\
\hline \multicolumn{2}{|c|}{ Área de abrangência de 185 x $185 \mathrm{~km}$. } \\
\hline \multicolumn{2}{|c|}{$\begin{array}{l}\text { Permite boas aplicações diretas até a escala de } \\
1: 25.000\end{array}$} \\
\hline
\end{tabular}

Fonte: NASA (2001b). 


\subsection{O satélite LANDSAT}

O LANDSAT é um sistema de satélite para observação da terra que adquire dados multiespectrais da superfície da terra de maneira contínua.

O primeiro satélite desta série foi lançado em 23 de julho de 1972, o Earth Resources Technology Satellite (ERTS-1). Foi o primeiro satélite não militar do mundo. Em 1975, a NASA renomeou oficialmente o programa ERTS para programa LANDSAT, para distingui-lo do programa de satélites oceanográficos SEASAT. (Tabela 2).

Tabela 2 - Programa LANDSAT.

\begin{tabular}{|c|c|c|c|c|}
\hline Satélite & Lançamento & Fim de operação & Sensores & Revisita \\
\hline LANDSAT-1 & $23 / 07 / 1972$ & $6 / 01 / 1978$ & $\begin{array}{l}\text { RBV, } \\
\text { MSS }\end{array}$ & 18 dias \\
\hline LANDSAT-2 & $22 / 01 / 1975$ & $05 / 02 / 1982$ & $\begin{array}{l}\text { RBV, } \\
\text { MSS }\end{array}$ & 18 dias \\
\hline LANDSAT-3 & $5 / 03 / 1978$ & $31 / 03 / 1983$ & $\begin{array}{l}\text { RBV, } \\
\text { MSS }\end{array}$ & 18 dias \\
\hline LANDSAT-4 & $16 / 07 / 1982$ & Standby, desde 07/87 & TM, MSS & 16 dias \\
\hline LANDSAT-5 & $01 / 03 / 1984$ & Em operação & TM, MSS & 16 dias \\
\hline LANDSAT-6 & $03 / 10 / 93$ & Perdido em 03/10/93 & $\begin{array}{c}\text { ETM, } \\
\text { MSS }\end{array}$ & \\
\hline LANDSAT-7 & $14 / 04 / 99$ & Em operação & ETM+ & 16 dias \\
\hline
\end{tabular}

Fonte: NASA (2001b).

O sensor ETM + do satélite LANDSAT 7 fornece 6 bandas multiespectrais com 30 m de resolução espacial, 1 banda termal com 60 m de resolução espacial e 1 banda pancromática com $15 \mathrm{~m}$ de resolução espacial, aumentando ainda mais as possibilidades de estudos (Tabela 3).

Tabela 3 - Características do sensor ETM+ (Enhanced Thematic Mapper Plus) do satélite LANDSAT 7.

\begin{tabular}{|c|c|c|}
\hline Bandas & Intervalo espectral (microns) & Resolução espacial (m) \\
\hline 1 & $0,45-0,515$ & 30 \\
\hline 2 & $0,525-0,605$ & 30 \\
\hline 3 & $0,63-0,690$ & 30 \\
\hline 4 & $0,75-0,90$ & 30 \\
\hline 5 & $1,55-1,75$ & 30 \\
\hline 6 & $10,40-12,5$ & 60 \\
\hline 7 & $2,09-2,35$ & 30 \\
\hline Pan & $0,52-0,90$ & 15 \\
\hline
\end{tabular}

Fonte: USGS (2001). 
O mapeamento temático a partir de cada uma dessas bandas depende ainda das características da área em estudo (região plana ou acidentada); época do ano (inverno ou verão); ou de variações regionais (Nordeste, Sudeste, Sul, Amazônia, Pantanal). Os trabalhos de interpretação das imagens tornam-se mais fáceis quando o fotointérprete tem conhecimento de campo.

Cada banda espectral do satélite LANDSAT apresenta características espectrais que a torna mais adequada a determinados estudos, como pode ser observado na Tabela 4.

Tabela 4 - Características espectrais do sensor TM do satélite LANDSAT 5 e principais aplicações.

\begin{tabular}{|c|c|c|}
\hline Banda & $\begin{array}{c}\text { Intervalo } \\
\text { espectral }(\mu \mathrm{m})\end{array}$ & $\begin{array}{l}\text { Principais características e aplicações das bandas TM do } \\
\text { satélite LANDSAT-5 }\end{array}$ \\
\hline 1 & $\begin{array}{l}(0,45-0,52) \\
\text { resol.espacial } \\
30 \mathrm{~m} \text { (azul) }\end{array}$ & $\begin{array}{l}\text { Apresenta grande penetração em corpos de água, } \\
\text { permitindo estudos batimétricos. Sofre absorção pela } \\
\text { clorofila e pigmentos fotossintéticos auxiliares } \\
\text { (carotenóides). Pode apresentar atenuação pela atmosfera. }\end{array}$ \\
\hline 2 & $\begin{array}{l}(0,52-0,60) \\
\quad(\text { verde })\end{array}$ & $\begin{array}{l}\text { Apresenta grande sensibilidade à presença de sedimentos } \\
\text { em suspensão, possibilitando sua análise em termos de } \\
\text { quantidade e qualidade. Boa penetração em corpos de } \\
\text { água. }\end{array}$ \\
\hline 3 & $\begin{array}{l}(0,63-0,69) \\
\text { (vermelho) }\end{array}$ & $\begin{array}{l}\text { Apresenta grande absorção da clorofila, permitindo bom } \\
\text { contraste entre as áreas ocupadas com vegetação. É a } \\
\text { banda mais utilizada para delimitar a mancha urbana, } \\
\text { incluindo identificação de novos loteamentos. Permite a } \\
\text { identificação de áreas agrícolas. }\end{array}$ \\
\hline 4 & $\begin{array}{l}(0,76-0,90) \\
\text { (infravermelho } \\
\text { próximo) }\end{array}$ & $\begin{array}{l}\text { Os corpos de água absorvem muita energia nesta banda, } \\
\text { permitindo o mapeamento da rede de drenagem e } \\
\text { delineamento de corpos de água. A vegetação verde reflete } \\
\text { muita energia Apresenta sensibilidade à morfologia do } \\
\text { terreno }\end{array}$ \\
\hline 5 & $\begin{array}{l}(1,55-1,75) \\
\text { (infravermelho } \\
\text { médio) }\end{array}$ & $\begin{array}{c}\text { Apresenta sensibilidade ao teor de umidade das plantas, } \\
\text { servindo para observar estresse na vegetação, causado por } \\
\text { desequilíbrio hídrico. }\end{array}$ \\
\hline 6 & $\begin{array}{l}(10,4-12,5) \\
\quad(\text { termal })\end{array}$ & $\begin{array}{l}\text { Apresenta sensibilidade aos fenômenos relativos aos } \\
\text { contrastes térmicos, servindo para detectar propriedades } \\
\text { termais de rochas, solos, vegetação e água. }\end{array}$ \\
\hline 7 & $\begin{array}{l}(2,08-2,35) \\
\text { (infravermelho } \\
\text { longe) }\end{array}$ & $\begin{array}{l}\text { Apresenta sensibilidade à morfologia do terreno. Esta } \\
\text { banda serve para identificar minerais com íonshidroxilas. } \\
\text { Potencialmente favorável à discriminação de produtos de } \\
\text { alteração hidrotermal. }\end{array}$ \\
\hline
\end{tabular}

Fonte: INPE (2001a). 
A Tabela 4 apresenta as principais aplicações do satélite LANDSAT 5.

O satélite LANDSAT 7 difere do anterior nos seguintes aspectos:

- Adição da banda pancromática com resolução de $15 \mathrm{~m}$.

- A banda 6 (infra vermelho termal) com ganhos diferentes e resolução espacial de $60 \mathrm{~m}$.

- Melhoramento no sistema de calibração do satélite, o que garante uma precisão radiométrica absoluta de $+/-5 \%$.

- Melhoramento na geometria de imageamento, o que determina uma precisão em imagens corrigidas apenas a partir de dados de efemérides de satélite e GPS, muito próxima da precisão obtida com imagens georreferenciadas com pontos de controle cartográficos. (LANDSAT 7, 2003).

\subsection{Interpretação visual de imagens}

"O processo de interpretação visual de imagens baseia-se em certos princípios de análise, que incluem métodos para detectar, dentificar e medir objetos observados a partir de uma perspectiva aérea ou orbital" (NOVO, 1995).

A interpretação visual dos dados de uso da terra é importante na definição de chaves de interpretação que caracterizam os diferentes usos a serem levantados.

As chaves de interpretação são descrições da imagem definida pela interação de vários elementos de reconhecimento: tonalidade, cor, tamanho, forma, textura, padrão, altura, sombreamento, localização e contexto.

Estes elementos são aplicados às imagens orbitais com algumas considerações, que se fazem necessárias em virtude das características dos sensores utilizados na obtenção de imagens orbitais.

A forma está relacionada à configuração geral de um objeto. A visualização das características morfológica do objeto depende da escala utilizada. Em escalas menores, a análise é realizada de maneira genérica, enquanto que nas escalas maiores, é possível a identificação de estádios de futebol, aeroportos, etc. Geralmente, as formas regulares indicam aspectos artificiais e as irregulares indicam 
aspectos naturais e ocorrem na ausência de formas geométricas definidas, como no caso das matas naturais (PEREIRA et al.,1985).

O tamanho dos objetos ou dos alvos constitui um fator de grande importância na identificação. A escala da imagem deve ser observada.

As sombras são resultantes da iluminação oblíqua da superfície pelo sol, no instante da tomada de registro pelos sensores. Muitos objetos são reconhecidos, nas imagens de satélite, pelas suas sombras podendo-se até inferir sua altura através dela.

A tonalidade é a resposta da quantidade relativa da luz refletida ou da radiação emitida registrada pelo sensor, resultante das propriedades físicas e químicas do alvo.

Padrão refere-se ao arranjo espacial dos objetos. A repetição de certas formas e seus relacionamentos estabelece padrões que ajudam a identificação de objetos através da fotointerpretação.

Segundo PEREIRA et al.(1985), a textura é produzida pela agregação de unidades muito pequenas para serem identificadas individualmente, passando a ser analisadas em conjunto.

Segundo HARALICK apud PEREIRA et al.(1985), quando uma parcela de área pequena de uma imagem tem diminuta variação dos componentes tonais primários, a propriedade dominante é a tonalidade. Quando uma parcela de área pequena tem grande variação dos componentes tonais primitivos, a propriedade dominante desta área é a textura.

Localização diz respeito à posição geográfica de um objeto, que é um elemento de reconhecimento que auxilia a interpretação à medida que se conhece, por exemplo, o clima, o tipo de vegetação, etc.

Relação de aspectos é a correlação dos fenômenos físicos, naturais e antrópicos. Através destes elementos é possível a identificação visual dos objetos na imagem.

De acordo com PEREIRA et al.(1985), dois aspectos particularmente importantes, no caso das imagens orbitais devem ser considerados: aspectos espectrais e temporais das imagens. 
Os aspectos temporais são de grande importância para a interpretação de imagens, pois grande parte dos alvos naturais é de natureza dinâmica, ou seja, apresentam variações no tempo. Devido às características repetitivas dos imageadores dos satélites, torna-se possível a análise das variações temporais que se apresentam através das mudanças nos padrões de tonalidade e de textura do alvo.

Para o levantamento de cobertura e uso da terra, a época do ano influencia em função da resposta espectral não diferenciada. Nas classes urbanas, o período chuvoso é o mais indicado, pois apresenta maior contraste entre as áreas urbanas construídas e a vegetação adjacente (PEREIRA et al., 1985).

Quanto aos aspectos espectrais, a escolha do canal ou banda a ser utilizada na análise visual é de grande importância e depende do objetivo do trabalho. O conhecimento prévio das características do alvo auxilia na escolha dos canais a serem utilizados no estudo.

A combinação das bandas na composição colorida permite a aquisição de maior quantidade de informação, pois o olho humano é mais sensível às cores do que aos tons de cinza, constituindo um produto de grande potencialidade para o mapeamento do uso do solo.

Segundo FORESTI (1987), a melhor combinação de bandas para estudos do uso do solo e para a expansão urbana na área metropolitana de São Paulo, foram as bandas 5, 3 e 4 (azul, verde e vermelho) e as bandas 2, 7 e 4 (azul, verde e vermelho).

\subsection{Técnicas de processamento digital de imagens}

"Denomina-se Processamento Digital de Imagens - PDI ao conjunto de técnicas para manipulação de imagens digitais no sentido de facilitar a extração de informações." (IBGE, 2001).

Segundo LOMBARDO (1996), a análise das imagens orbitais para inferir dados da morfologia urbana envolve interpretação visual e processamento digital. $\mathrm{Na}$ interpretação visual são extraídas informações a partir dos aspectos observacionais das imagens digitais, em papel ou em transparências, como análise espectral, elementos texturais, tonalidade e relação de contexto. 
De acordo com CRÓSTA (1992), a necessidade de processamento advém do fato da imagem conter uma quantidade muito maior de informações do que o olho humano conseguiria perceber, portanto faz-se necessário torna-la mais visível, ou representala de uma forma pela qual ela possa ser percebida.

O processamento digital de imagens envolve a análise espectral e está fortemente relacionado a quatro operações básicas: pré-processamento, realce, transformação de imagens e classificação (EASTMAN, 1998).

\subsubsection{Pré-processamento}

O pré-processamento ou correção das imagens é o processamento inicial dos dados brutos para a calibração radiométrica da imagem, correções de distorções geométricas e remoção de ruído.

As distorções decorrentes do processo de obtenção de informações da superfície terrestre através do sensoriamento remoto orbital são provenientes de diversos fatores:

- variações atmosféricas do momento;

- problemas inerentes ao próprio sensor (componentes mecânicos, óticos e elétricos);

- comportamento do satélite (rotação em torno do eixo vertical, balanço frontal e balanço lateral);

- geometria no instante de obtenção da imagem (deformações devido à forma e ao movimento de rotação da Terra, altura do Sol, posição do satélite em relação ao Sol);

- imperfeições radiométricas (ruídos gerados no processamento e transmisão, valores elevados uniformemente, etc);

- distorções do scanner, etc.

O sinal registrado pelo sensor em cada pixel pode não corresponder à verdadeira radiância da respectiva área, porque o sinal é atenuado pela absorção ou desviado pela dispersão causada pela atmosfera. A energia eletromagnética ao atravessar a 
atmosfera é parcialmente absorvida, refletida ou espalhada. A correção radiométrica minimiza estas distorções evitando resultados errôneos.

Segundo NOVO (1989), a função dos programas de correção geométrica é reorganizar os pixels da imagem em relação a um determinado sistema de projeção cartográfica. A correção geométrica pode ser obtida através de técnicas de reamostragem dos pixels que reformatam uma determinada cena em uma dada base cartográfica. Para isso, são necessários pontos de controle no terreno facilmente identificáveis na base cartográfica e na cena a ser corrigida geometricamente.

A transformação espacial que combina duas imagens diferentes de uma mesma área de modo que sejam perfeitamente coincidentes no espaço é conhecido como registro. O registro facilita a superposição de imagens distintas, de modo que as características geométricas comuns às duas imagens estejam na mesma localização geográfica/imagem, corrigindo assim as diferenças de deslocamentos nas direções horizontais e verticais.

\subsubsection{Realce}

O realce envolve técnicas que aumentam a distinção visual das feições na imagem, melhorando o contraste entre os alvos. Novas imagens são criadas das imagens originais de modo a aumentar a quantidade de informações que podem ser interpretadas visualmente dos dados.

As principais técnicas utilizadas para o realce de imagens: ampliação de contrastes, geração de composições coloridas e filtragens espaciais..

\section{Composição colorida}

A composição colorida consiste na combinação de 3 bandas espectrais de uma imagem de satélite para a geração de uma composição colorida falsa-cor. As bandas selecionadas devem conter as informações espectrais que se deseja, de forma a destacá-las. Diferentes combinações das bandas fazem com que as informações sejam percebidas de forma diferente. 


\section{Filtragem espacial}

As técnicas de filtragem são transformações da imagem pixel a pixel, que dependem não apenas do nível de cinza de um determinado pixel, mas também dos valores dos níveis de cinza dos pixels vizinhos, na imagem original. Existem duas maneiras de se implementar as técnicas de filtragem de freqüência: o processo conhecido por convolução que opera no domínio espacial de uma imagem ou a análise de Fourier que opera no domínio das freqüências que compõem a imagem (CRÓSTA, 1992).

Segundo CRÓSTA (1992), a filtragem no domínio de frequiências é sem dúvida mais poderosa e precisa, mas também muito mais complexa.

A convolução, por sua vez, é mais simples e fácil de implementar, atendendo satisfatoriamente à maioria das necessidades em termos de imagens de sensoriamento remoto. São realizadas com o auxílio de sub-matrizes de dimensões físicas e pré-determinadas chamadas de máscaras ou janelas móveis. Podem ser:

- Filtros passa-baixa ou suavização ("smoothing"), atenuam ou eliminam os componentes de altas frequiências no domínio espacial da imagem deixando "passar" somente as baixas freqüências. Os componentes de alta freqüência caracterizam as bordas e outros detalhes finos de uma imagem, de forma que o efeito resultante é o borramento da imagem. (GONZÁLES e WOODS, 2000). A maior utilização é na remoção de ruídos eletrônicos, comuns em imagens de sensoriamento remoto. Os tipos mais comuns são: filtros de média, média ponderada, moda ou mediana.

- Filtros passa-alta ou realce de borda. São filtros que atenuam ou eliminam os componentes de baixa freqüência espacial, deixando passar apenas os de alta - freqüência, normalmente expressas por bordas ou limites entre áreas de diferentes valores de níveis de cinza. Neste caso, quanto menor as máscaras utilizadas, menores serão os detalhes a serem realçados na imagem. Os tipos mais comuns são os filtros: Laplacianos, Laplacianos + imagens originais e direcionais (CRÓSTA, 1992). 
- Filtro passa banda é o menos utilizado por ser de difícil implementação. Remove regiões selecionadas de freqüência entre alta e baixa frequiência (CRÓSTA, 1992).

\section{Manipulação de contraste}

A manipulação de contraste modifica os níveis de cinza ou valores digitais de uma imagem de modo a melhorar a qualidade visual da imagem facilitando a interpretação.

Uma imagem digital pode ser vista como uma matriz formada por $\mathrm{x}$ linhas e $\mathrm{y}$ colunas, onde cada elemento da matriz possui um atributo z correspondente ao nível de cinza. O nível de cinza é a intensidade da energia eletromagnética refletida ou emitida pelos diferentes materiais da superfície da Terra e que é medida pelo sensor.

A distribuição estatística dos níveis de cinza presentes numa imagem pode ser representada pelo histograma, conhecido também como distribuição de intensidade ou função de densidade de probabilidade (PDF).

A manipulação do histograma permite várias opções de contraste na imagem, sendo as principais:

\section{Aumento linear de contraste ("contrast stretch")}

É a forma mais simples e comum de realce de imagem.

É realizado através de uma função de transferência dada por uma reta onde apenas 2 parâmetros são controlados: a inclinação da reta e o ponto de interseção com o eixo x. A inclinação controla a quantidade de aumento de contraste e o ponto de interseção com o eixo x controla a intensidade média da imagem final (Figura 5).

O objetivo deste processamento é o aumento da amplitude de variação dos níveis de cinza, aumentando o contraste entre os alvos. 


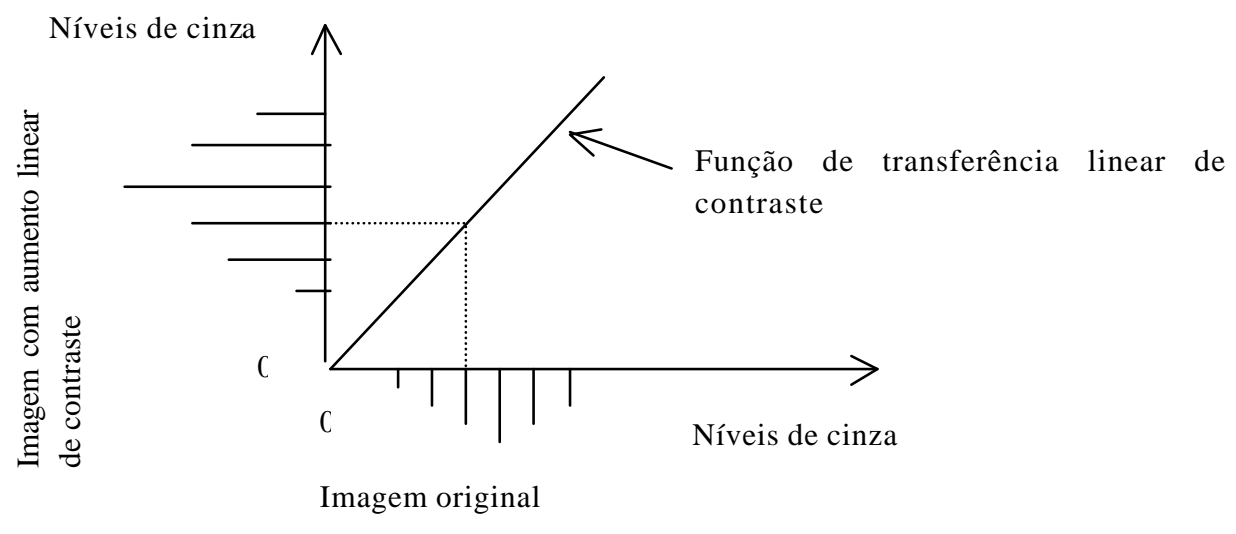

Figura 5 - Histograma com aumento linear de contraste (ALC)

Fonte: CRÓSTA, 1992.

\section{Fatiamento de histograma ("slicer")}

A operação consiste simplesmente em realçar os pixels cujas intensidades se situam dentro de um intervalo específico (a fatia), isto é, entre um máximo e um mínimo, associando ao intervalo, uma cor diferente ou símbolo (interpretação visual).

Este processo divide a imagem em regiões que devem corresponder às áreas de interesse da aplicação. Entende-se por regiões um conjunto de pixels contíguos, que se espalham bidirecionalmente e que apresentam uniformidade (Figura 6).

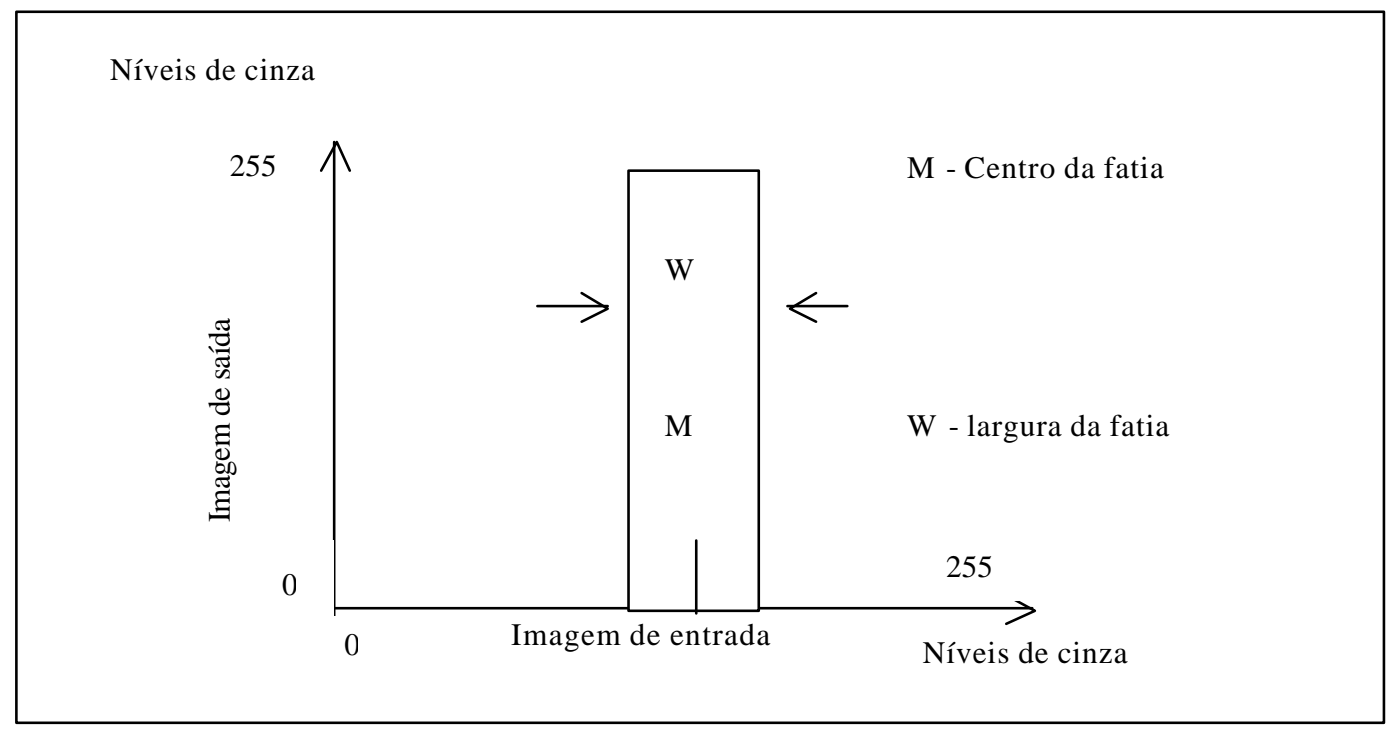

Figura 6 - Função de transferência para o fatiamento de níveis de intensidade.

Fonte: CRÓSTA (1992). 


\subsubsection{Transformação de imagens}

\section{Operação aritmética entre imagens}

As operações aritméticas são utilizadas para a realização de diversas análises nas imagens multiespectrais e/ou multitemporais de sensoriamento remoto. Estas operações reduzem a dimensionalidade dos dados originais. As bandas multiplicadas ou divididas duas a duas produzem novas bandas que conterão as informações das bandas originais, porém com alguma perda de informação. O resultado é uma única imagem representando o resultado da combinação das imagens originais de acordo com alguma regra matemática, realizada pixel a pixel.

A adição e multiplicação de imagens servem para realçar similaridades espectrais entre bandas ou diferentes imagens enquanto que a subtração e a divisão servem para realçar diferenças espectrais.

Entre as operações aritméticas, a divisão entre bandas (razão entre bandas) é a operação aritmética mais comum. A propriedade mais importante da divisão entre bandas é a capacidade de realçar intensamente diferenças espectrais de um par de bandas. São utilizados principalmente para índices de biomassa ou vegetação e também na identificação de zonas de alteração hidrotermal relacionada a concentrações de minerais; além disso, suaviza os efeitos de topografia e de atmosfera.

O exemplo mais comum de operação aritmética entre imagens é o Índice de Vegetação.

Os índices de vegetação foram desenvolvidos principalmente para o monitoramento da quantidade (distribuição) e qualidade (vigor, saúde) da vegetação nas áreas imageadas pelo satélite.

Através da combinação de bandas espectrais, os números de parâmetros nas medições multiespectrais são reduzidos para um único parâmetro, obtendo-se assim respostas espectrais diferentes, minimizando o efeito de fatores como o solo, luminosidade e atmosfera. 
A maior parte dos índices está baseada em interações entre a vegetação e a energia eletromagnética no comprimento de onda nas faixas do vermelho e do infravermelho próximo (Figura 7).

A reflectância da vegetação na região do vermelho (cerca de $0,6-0,7 \mu \mathrm{m}$ ) é baixa devido à absorção pelos pigmentos das folhas (principalmente clorofila). A região do infravermelho (aproximadamente 0,8-0,9 $\mu \mathrm{m}$ ), entretanto, mostra alta reflectância por causa do espalhamento por parte da estrutura das células das folhas (Tabela 5).

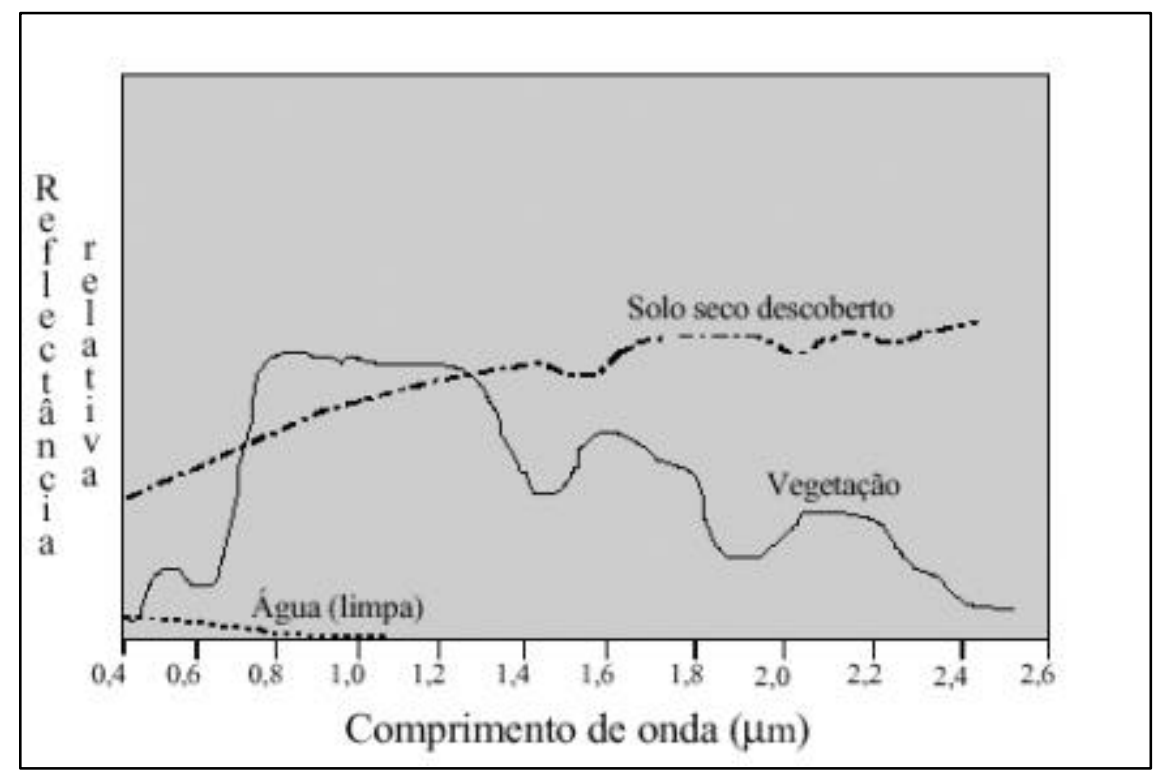

Figura 7 - Comportamento espectral da vegetação

Fonte: Adaptado de LILLESAND \& KIEFER (1987).

Um índice de vegetação muito simples pode ser obtido dividindo a medida da reflectância no infravermelho pela reflectância no vermelho. Áreas de vegetação densa terão como resultado um valor de índice muito alto. 
Tabela 5 - Comportamento espectral da vegetação

\begin{tabular}{|c|c|}
\hline REFLECTÂNCIA & COMPORTAMENTO \\
\hline $0,58 \mu \mathrm{m}$ & $\begin{array}{l}\text { Reflectância responsável pela percepção da cor verde da } \\
\text { vegetação }\end{array}$ \\
\hline Até $0,7 \mu \mathrm{m}$ & $\begin{array}{c}\text { Absorção da radiação incidente pelos pigmentos da planta } \\
\text { reflectância baixa }(\rho<0,2)\end{array}$ \\
\hline $0,7 \mu \mathrm{m}$ a $1,3 \mu \mathrm{m}$ & $\begin{array}{c}\text { Interferência da estrutura celular } \\
\text { alta reflectância da vegetação }(0,3<\rho<0,4)\end{array}$ \\
\hline $1,3 \mu \mathrm{m}$ a $2,5 \mu \mathrm{m}$ & a reflectância é dominada pelo conteúdo de água das folhas \\
\hline $1,4 \mu \mathrm{m}$ a $1,95 \mu \mathrm{m}$ & $\begin{array}{c}\text { são dois máximos de absorção de água. Correspondem também } \\
\text { as bandas de absorção atmosférica. }\end{array}$ \\
\hline
\end{tabular}

Fonte: NOVO (1995).

Embora um razoável número de variantes desta lógica básica tenha sido experimentado, a única que recebeu mais atenção é a do índice de vegetação de diferença normalizada (NDVI). Pode ser obtido através da seguinte equação:

$\mathrm{NDVI}=\frac{(N I R-R)}{(N I R+R)}$

Onde NIR = infravermelho próximo

$\mathrm{R}=$ Vermelho

O NDVI possui intervalo de $-1 \geq$ NDVI $\geq 1$

Somente os valores positivos correspondem às zonas com vegetação.

Os valores negativos, gerados por uma reflectância muito maior na região do visível do que na região do infravermelho podem ser devidos às nuvens, solo exposto e rochas.

Os valores NDVI dos diferentes sensores não podem ser diretamente comparados, pois os sistemas sensores obtêm dados em intervalos espectrais não coincidentes e com largura de bandas distintas.

Em áreas urbanas os índices de vegetação indicam principalmente a qualidade habitacional. A presença vegetação nas áreas urbanas indica a presença de áreas de lazer, parques, jardins e quintais. 


\subsubsection{Classificação}

Segundo NOVO (1995), as técnicas de classificação digital implicam na implementação de um processo de decisão para que o computador possa atribuir certo conjunto de pontos da imagem (pixels) a uma determinada classe.

São gerados neste processo, mapas temáticos ou cartas temáticas correspondentes aos temas de interesse, de acordo com critérios bem definidos. A análise visual dos dados das imagens é auxiliada com técnicas quantitativas para identificação automática de feições na cena, para reconhecimento de padrões e objetos homogêneos. Cada pixel da imagem original é classificado em alguma das classes ou temas definidos e representado por símbolos gráficos ou cores.

A maioria dos classificadores baseia-se exclusivamente na detecção da assinatura espectral (isto é, padrões de respostas espectrais) de classes de cobertura do solo. Neste caso, para que a classificação seja bem sucedida, é necessário que as assinaturas espectrais dos alvos sejam bem definidas e distintas entre si, permitindo a distinção dos alvos com segurança. Para as áreas urbanas nem sempre isso é possível.

Os classificadores podem ser divididos em classificadores "pixel a pixel" e classificadores por regiões, conforme o processo de classificação empregado (INPE, 2002a).

Classificadores pixel a pixel agregam regiões homogêneas a partir das informações espectrais de cada pixel. Estes classificadores podem ser separados em métodos estatísticos (utilizam regras da teoria de probabilidade) e determinísticos (não utilizam probabilidade).

Classificadores por regiões utilizam, além das informações espectrais de cada pixel, as informações espaciais que envolvem as relações com seus vizinhos. As áreas homogêneas são agrupadas baseadas nas propriedades espectrais e espaciais das imagens.

De acordo com a forma como a classificação é conduzida, a classificação de imagens pode ser supervisionada e não supervisionada.

$\mathrm{Na}$ classificação supervisionada as características dos tipos específicos de cobertura do solo já são conhecidas, enquanto que na classificação não supervisionada, o 
analista busca definir as categorias do solo existentes na imagem em certos níveis de generalização. A classificação supervisionada é mais adequada às necessidades do usuário do que a não supervisionada pois leva em consideração informações fornecidas pelo usuário, a verdade terrestre ou mapas de referência, enquanto que o método não supervisionado, o algoritmo agrupa os pixels semelhantes ou separa os pixels em grupos diferentes. $\mathrm{O}$ usuário apenas informa o número de classes desejado ou um critério considerado estável.

A decisão quanto à similaridade entre as assinaturas espectrais é realizada através de análises estatísticas. Diversas técnicas são utilizadas para a tomada de decisão, frequientemente denominados classificadores. Os classificadores podem ser rígidos ou relativos.

Os classificadores rígidos (tradicionais), associam os pixels da imagem à classe de cobertura cuja assinatura espectral é mais similar. Nesta classificação, cada pixel pertence a uma e somente uma única classe.

Os classificadores relativos adotam a abordagem fuzzy para a avaliação dessa associação e do grau com que um pixel pertence a todas as classes envolvidas, incluindo as classes desconhecidas. Os métodos de classificação relativa podem ser baseados na teoria de probabilidade Bayesiana, teoria Dempster-Shafer e teoria de conjuntos fuzzy, entre outros (EASTMAN, 1998). As questões de maior significância são tratadas por eles, como a análise de misturas, avaliação de evidência em suporte às classes envolvidas, reconhecimento de crescimento incompleto e presença de classes desconhecidas.

A exatidão da classificação envolve a identificação das classes encontradas nas imagens às regiões visitadas no campo para os mesmos locais.

As avaliações estatísticas de exatidão podem então ser derivadas para a área de estudo inteira, assim como para as classes individuais.

\section{Classificação supervisionada}

A classificação supervisionada é realizada quando existem regiões da imagem em que o usuário dispõe de informações que permitem a identificação dos tipos específicos de cobertura do solo. Para a classificação supervisionada, o usuário deve 
identificar na imagem, áreas representativas de cada classe de interesse. Essas áreas são as chamadas áreas de treinamento, onde serão reconhecidas as assinaturas espectrais das classes de interesse.

Nas áreas de treinamento, é importante que as amostras contenham as informações relativas às classes de interesse e que sejam homogêneas, mas ao mesmo tempo devem incluir toda a variabilidade dos níveis de cinza do tema em questão. A aquisição de mais de uma área de treinamento para a mesma classe é recomendada, utilizando o maior número de informações disponíveis, como trabalhos de campo, mapas, etc.

As assinaturas espectrais são desenvolvidas a partir da análise estatística das reflectâncias dos pixels contidos em cada áreas de treinamento.

Definida as assinaturas espectrais de categorias que se deseja, cada pixel da imagem é comparado a cada uma das assinaturas criadas e então, associado à assinatura mais similar.

Segundo JENSEN (1986), alguns métodos estatísticos de classificação supervisionada multiespectral "pixel a pixel" mais conhecidos são: máxima verossimilhança (MAXVER) e distância mínima, além do método do paralelepípedo, que não é um método estátistico mas geométrico.

Cada um deles emprega uma lógica diferente para atribuir pixels a classes.

O método do paralelepípedo considera uma área no espaço de atributos definido pelos valores de níveis de cinza, máximos e mínimos do conjunto de treinamento ao redor do conjunto de treinamento. Essa área tem a forma de um quadrado ou paralelepípedo (Figura 8). Todos os pixels situados dentro do paralelepípedo são classificados como pertencentes àquela categoria.

Este é o classificador mais rápido, podendo, porém, ocorrer classificações incorretas. $\mathrm{O}$ ajuste das áreas ocorre de frma que tomam pixels que provavelmente deveriam ser atribuídos a outras classes. Pixels com valores que caem nesta superposição são atribuídos à última assinatura, seguindo a ordem na qual os nomes das assinaturas foram introduzidos no módulo (CRÓSTA, 1992). 


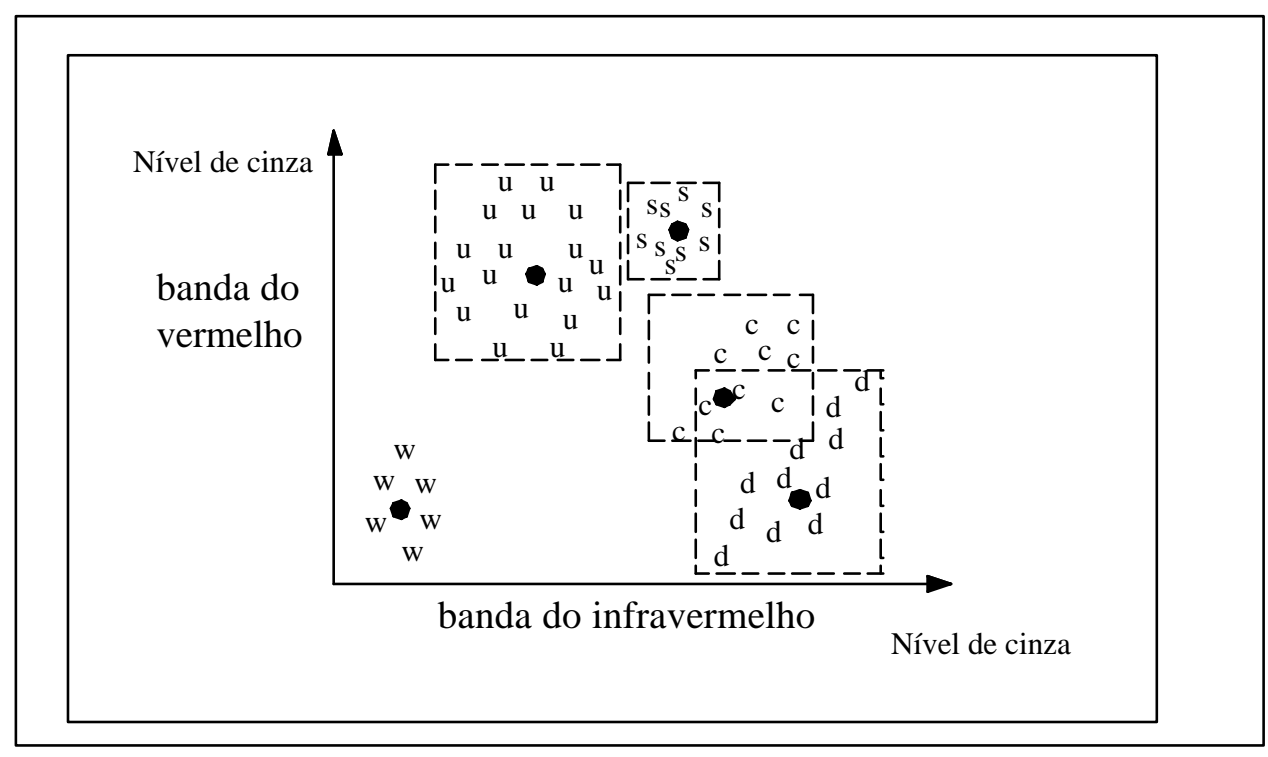

Figura 8 - Classificação supervisionada, método do paralelepípedo.

Fonte: EASTMAN (1998).

O classificador de distância mínima à média calcula a distância do valor de reflectância de um pixel à média espectral do arquivo de assinaturas e atribui ao pixel a categoria com a média mais próxima (Figura 9). Existem duas formas para o cálculo da distância, a Distância Euclidiana, ou bruta, e a Distância Normalizada.

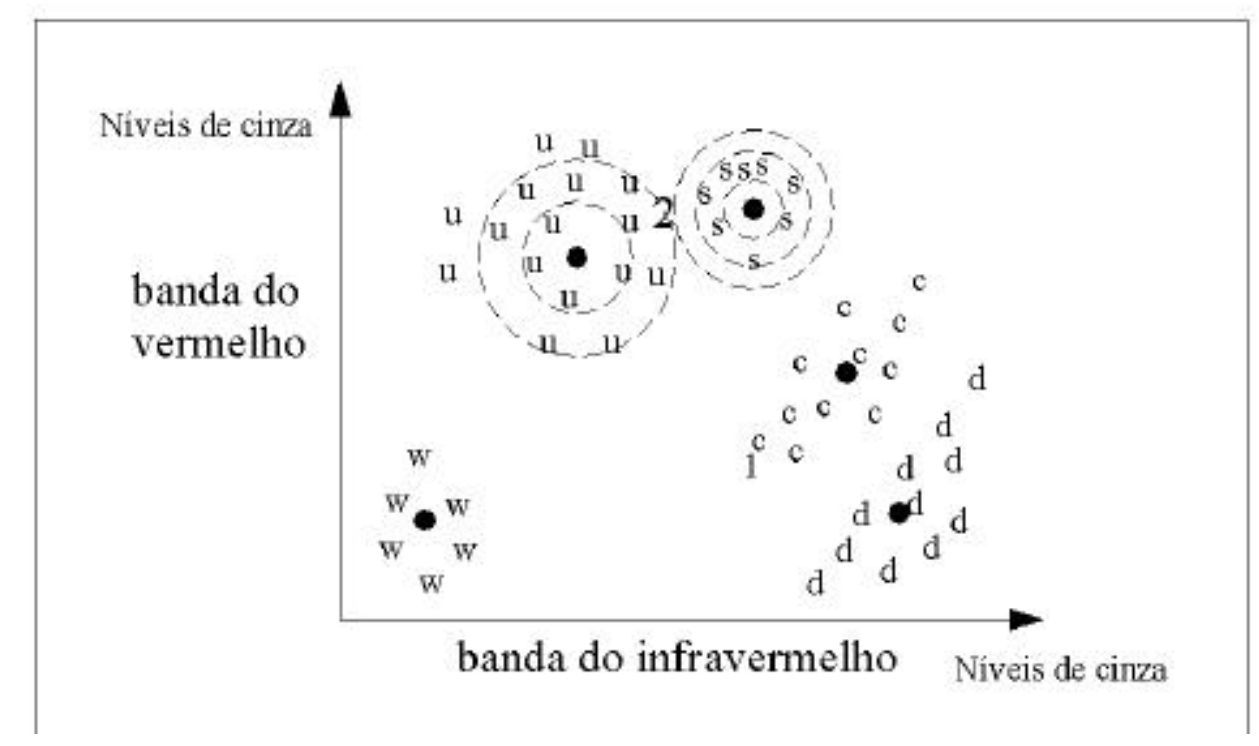

Figura 9 - Classificação supervisionada, método da distância mínima.

Fonte: EASTMAN (1998). 
Segundo EASTMAN (1998), no classificador por Máxima Verossimilhança (MAXVER), a distribuição dos valores de reflectância em uma área de treinamento é descrita por uma função de densidade de probabilidade, desenvolvida com bases na estatística Bayesiana. Este classificador avalia a probabilidade de um determinado pixel pertencer a uma categoria e classifica o pixel para a categoria a qual ele tem a maior probabilidade de associação (Figura 10).

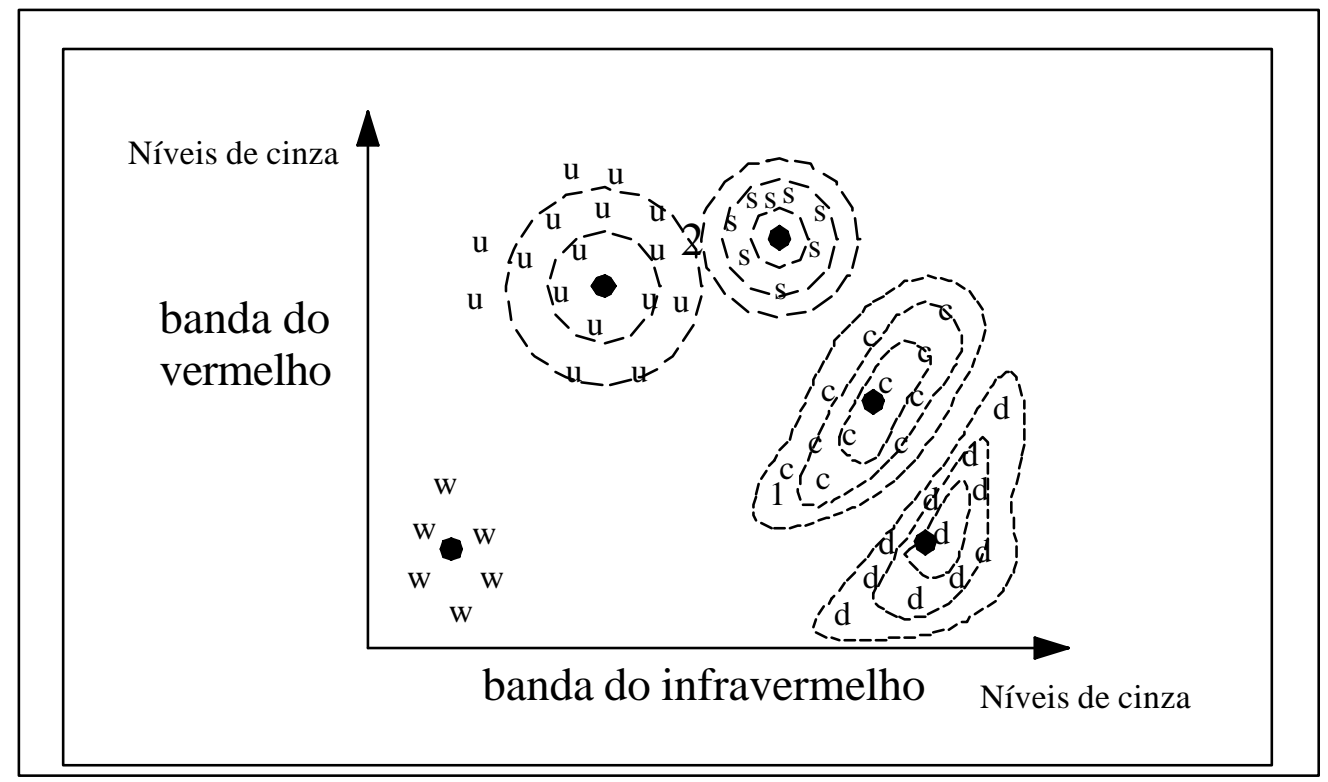

Figura 10 - Classificação supervisionada, máxima verossimilhança Fonte: EASTMAN (1998).

\section{Classificação não supervisionada}

Na classificação não supervisionada os pixels da imagem são examinados e divididos em agrupamentos espectrais naturais predominantes presentes na imagem. $\mathrm{O}$ agrupamento é realizado através de algoritmos de agrupamentos (cluster) que separa os pixels em grupos homogêneos cujos padrões de reflectância são similares. Os algoritmos de "clustering" não assumem qualquer conhecimento prévio da distribuição de densidade de probabilidade dos temas, como ocorre no algoritmo de máxima verossimilhança. 
O analista identifica esses agrupamentos como classes de cobertura do solo da melhor forma possível, através de uma combinação de sua familiaridade com a região estudada e visitas para levantamentos de verdade de campo.

Muitas vezes há a necessidade de reclassificação das classes, agrupando-as ou desagregando-as.

Alguns métodos comuns de "cluster" são o algoritmo K-Médias (MOREIRA, 2001) e o de busca pelo pico do histograma (EASTMAN, 1998).

No algoritmo K-Médias a definição das classes é feita, tendo como critério agrupador a distância Euclidiana entre pixels no espaço de atributos espectrais (canais). A partir de centros iniciais de possíveis classes, o programa reagrupa os pixels em interações sucessivas, até que o centro do "cluster" seja mantido constante ou até que se atinja o número de iterações previstas pelo programa (NOVO, 1995).

A técnica de seleção pelo pico do histograma, equivale a buscar os picos em um histograma unidimensional, onde um pico é definido como um valor de freqüência maior que a de seus vizinhos de cada lado. Uma vez que os picos tenham sido identificados, todos os valores observados são associados ao pico mais próximo. Em conseqüência, as divisões entre as classes tendem a cair no ponto da média entre os picos (EASTMAN,1998).

\section{Classificação híbrida}

São aquelas em que o analista utiliza uma classificação não supervisionada como base para a seleção de amostras de treinamento para realizar uma classificação supervisionada (NOVO, 1995). As técnicas de classificação híbrida são consideradas relativamente mais eficientes e confiáveis do que as duas técnicas, a supervisionada e a não supervisionada, quando utilizadas isoladamente.

Segmentação de imagens.

Segundo INPE (2002), a segmentação de imagens é um processo anterior à classificação onde os objetos relevantes são extraídos para a aplicação desejada. 
Este processo divide a imagem em regiões que devem corresponder às áreas de interesse da aplicação. Entende-se por regiões um conjunto de pixels contíguos, que se espalham bidirecionalmente e que apresentam uniformidade. A divisão em porções consiste basicamente em um processo de crescimento de regiões, de detecção de bordas ou de detecção de bacias (INPE, 2002).

\section{Matriz de confusão ou de erros ("confusion matrix" ou "error matrix")}

A avaliação da precisão da imagem final produzida no processo de classificação, supervisionada ou não-supervisionada, é um passo vital. $O$ processo envolve a identificação de um conjunto de amostras locais, que é visitado no campo. A cobertura do solo encontrada no campo é comparada então para que seja traçada na imagem para o mesmo local. Avaliações estatísticas de precisão podem ser derivadas para a área de estudo inteira e para as classes individuais.

A matriz de confusão ou de erros avalia o resultado de uma classificação, comparando os dados da verdade de campo com os da classificação.

Os erro de comissão são informações na matriz sobre quantos pixels estão sendo incluídos erroneamente em uma classe particular e os erros de omissão são informações sobre quantos pixels estão sendo excluídos erradamente da classe que pertenceriam. Estas informações podem ser usadas para refinar a classificação, avaliar a precisão do procedimento de classificação empreendida e sugestionar métodos para melhorar a classificação.

Os erros de inclusão e omissão são calculados automaticamente a partir da interseção dos resultados da classificação da área de estudo com as áreas testes definidas especialmente para checar os resultados obtidos e determinadas a partir do uso de dados de verdade terrestre.

O índice Kappa é um dos métodos utilizados para avaliar a concordância entre a verdade terrestre e o mapa temático. A grande vantagem do uso da estatística Kappa é que no cálculo do coeficiente Kappa incluem-se todos os elementos da matriz de erro e não somente os elementos da diagonal principal (MOREIRA, 2001).

A partir da matriz de erros, o índice Kappa pode ser calculado: 


$$
K=\frac{N \sum_{i=1}^{r} x_{i i}-\sum_{i=1}^{r} x_{i+} x_{+i}}{N^{2}-\sum_{i=1}^{r} x_{i+} x_{+i}}
$$

onde:

r é o número de linhas na tabela de classificação;

$x_{i i}$ é o número de combinações ao longo da diagonal;

$x_{i+}$ é o número total de observações na linha i;

$x_{+i}$ é o número total de observações na coluna i;

$N$ é o número total de células;

+ = representa o somatório de cada linha e coluna;

Dividindo o numerador e o denominador por $\mathrm{N}^{2}$

$$
K=\frac{\boldsymbol{\theta}_{1}-\boldsymbol{\theta}_{2}}{1-\boldsymbol{\theta}_{2}}
$$

onde $\boldsymbol{\theta}_{1}=\frac{\sum_{i=1}^{r} x_{i i}}{N}$

$\theta_{2}=\frac{\sum_{i=1}^{r} x_{i+} x_{+1}}{N^{2}}$

O valor da estatística Kappa, determinado através da equação acima, é comparada aos valores contidos na Tabela 6, desenvolvida por LANDIS e KOCH (1977). 
Tabela 6 - Qualidade da classificação associada aos valores da estatística Kappa

\begin{tabular}{|l|l|}
\hline Valor de Kappa & Qualidade do mapa temático \\
\hline$<0,00$ & Péssimo \\
\hline $0,00-0,20$ & Ruim \\
\hline $0,20-0,40$ & Razoável \\
\hline $0,40-0,60$ & Boa \\
\hline $0,60-0,80$ & Muito boa \\
\hline $0,80-1,00$ & Excelente \\
\hline
\end{tabular}

Fonte: MOREIRA (2001).

\subsection{Sensoriamento remoto em áreas urbanas.}

As áreas urbanas apresentam características que tornam complexa a sua classificação, pois não apresentam continuidade ou homogeneidade. São áreas formadas por diversos materiais que refletem ou irradiam a energia eletromagnética de maneiras diversas, apresentando grande amplitude espectral e altas freqüências espaciais dificilmente separáveis. A heterogeneidade espectral é devida à composição dos alvos, que são formados por diversos materiais: concreto e asfalto nas vias e construções, telhados de diferentes materiais (fibrocimento, telhas, lajes), solo exposto, áreas verdes, praças, árvores, etc.

Os sensores remotos se mostram eficazes para diversos estudos urbanos, pois abrangem grandes áreas, fornecem informações contínuas, a um custo relativamente baixo em comparação às fotografias aéreas.

Algumas pesquisas mostram que a integração do Sistema de Informações Geográficas (SIG) e sensoriamento remoto podem fornecer subsídios para tomada de decisão no planejamento do uso urbano, como pode ser visto em COSTA (1996). A integração do mapa de uso do solo elaborado através de imagens de satélite e o modelo de aptidão física do solo obtido através do SIG permitiram definir áreas apropriadas ou inadequadas ao uso do solo, fornecendo informações úteis ao 
planejamento urbano. Estudos de MASSER (2001), também integram dados de sensoriamento remoto com os Sistemas de Informações Geográficas, assim como YUAN et al.(1997).

Existem vários estudos para classificação de imagens de satélite em áreas urbanas. Quando as classes de interesse são conhecidas previamente (a priori), técnicas de classificação supervisionadas são largamente utilizadas (CAMPBELL, 1996 apud FOODY, 2000). O objetivo é alocar cada pixel (ou outra unidade espacial definida como um campo ou uma parcela do solo) para uma classe de cobertura do solo que tenha a maior similaridade com o conjunto definido no estágio de treinamento da classificação. Os tipos de cobertura do solo urbano e sua distribuição aérea são dados fundamentais, requeridos para uma grande variedade de estudos nas ciências físicas e sociais, bem como para os municípios com o propósito de planejamento.

A utilização de sensores LANDSAT MSS e o Thematic Mapper TM foram largamente utilizados para os estudos do uso do solo urbano. Devido à baixa resolução destes sensores, a classificação da cobertura do solo só era possível nos níveis 1 e 2 do Sistema Anderson (ANDERSON et al.,1976). Alguns estudos utilizando estes sensores incluem: RIDD e LIU (1998); MATTIKALLI (1997).

Sistemas sensores do satélite SPOT com 10 e 20 m de resolução espacial também estão sendo muito utilizados para análise do uso do solo urbano, chegando aos níveis 2 e 3 do Sistema Anderson de classificação do uso do solo (ANDERSON et al. 1976), como mostrado em trabalhos como o de BARALDI e PARMIGGIANI (1991).

Diversos estudos urbanos foram realizados com scanners aerotransportados (Airborne Scanners) com 3-15m/pixels de resolução como Thermal Infrared Multispectral Scanner (TIMS) e o simulador TM (NS001), entre eles, QUATTROCHI e RIDD (1998).

Segundo STEFANOV (2001), novos sensores com melhores resoluções espectrais e temporais como o Advanced Spaceborne Thermal Emission and Reflection Radiometer (ASTER), o Enhanced TM Plus (ETM+), o simulador aerotransportado airborne MODIS/ASTER (MASTER) ou IKONOS estão permitindo estudos ainda mais precisos para a classificação da cobertura do solo. 
Os dados de radar também são muito utilizados nos estudos urbanos. HAACK e BECHDOL (1990), utilizaram dados de radar para o mapeamento do uso do solo na África oriental. Os dados das imagens do radar foram utilizados de forma independente e em combinação com imagens tradicionais de dados de sensores ópticos aerotransportados. Os resultados mostraram que os sensores combinados apresentaram uma melhor acurácia no mapeamento do que quando se utilizavam os sensores independentemente. Por outro lado, os dados dos radares mostram-se tão úteis quanto os dados ópticos, quando utilizado independentemente dos sensores ópticos.

Significantes melhorias na precisão da classificação das áreas urbanas tem sido atingidas utilizando uma variedade de tentativas sofisticadas.

\section{Utilizando Redes Neurais}

Segundo HAYKIN (1994): "as Redes Neurais Artificiais são processadores massivamente paralelos e distribuídos que têm uma propensão natural para armazenar o conhecimento proveniente da experiência e torná-lo útil. Desta forma, assemelhando-se ao cérebro humano em dois aspectos:

- o de que o conhecimento é adquirido pela rede através de um processo de aprendizado e

- o de que as intensidades das conexões entre neurônios, conhecidas como pesos sinápticos, são usadas para armazenar o conhecimento."

De acordo com NISHIDA (1998), as redes neurais são "o modelo neurológico programado para aprender" e aprender é uma capacidade que a Rede Neural Artificial possui devido à interconexão entre seus neurônios, que ocorre em um grau similar ao da interconexão ocorrida com os neurônios biológicos e não encontrado em técnicas de cálculo convencionais.

Portanto, uma Rede Neural Artificial pode ser definida como uma estrutura computacional que tem como objetivo permitir a implementação de modelos matemáticos que representem a forma como o cérebro humano processa as informações que adquire. 
As redes neurais têm sido alvo de grande interesse nos últimos anos, segundo a STATSOFT (2002) e estão sendo aplicadas com sucesso em uma grande variedade de problemas, nas mais diversas áreas: financeira, medicina, engenharia, geologia e física. As redes neurais são técnicas sofisticadas de modelagem capazes de modelar funções extremamente complexas. "As redes neurais aprendem pelo exemplo". O usuário da rede neural recolhe dados representativos, e executa algoritmos de treinamentos para aprender automaticamente a estrutura dos dados. Embora o usuário necessite ter algum conhecimento heurístico de como selecionar e preparar os dados, de como selecionar uma rede neural apropriada, e de como interpretar os resultados, o nível de conhecimento que o usuário necessita para aplicar com sucesso a rede neural é muito menor do que seria se ele utilizasse (para o exemplo) alguns outros métodos estatísticos mais tradicionais.

SERPICO et al. (1996), fizeram uma análise experimental utilizando modelos de redes neurais para classificação supervisionada de multisensores de dados de sensoriamento remoto. Nos anos recentes, a comunidade de sensoriamento remoto tem dado atenção às redes neurais para classificação de dados, principalmente por que não requer nenhum conhecimento prévio da distribuição estatística dos dados e é caracterizado pelo intrínseco paralelismo e rápida classificação.(BISHOP et al, 1992 apud SERPICO et al.,1996). Por outro lado, algumas dificuldades aparecem quando se utilizam redes neurais, relativos a escolha do modelo neural, a arquitetura das redes, a dependência dos resultados da classificação às condições de treinamento e a dificuldade com a interpretação do comportamento das redes.

PAOLA e SCHOWENGERDT (1995) comparam duas classificações de uso do solo urbano utilizando redes neurais e classificadores por máxima verossimilhança, realizadas com uma imagem LANDSAT TM na região de Tucson, Arizona e Oakland, Califórnia. Para a imagem de Tucson, a porcentagem de pixels que combinavam (iguais) nos dois mapas de classificação foi somente de 64,5\% , enquanto que na imagem de Oakland foi de 83,3\%. Embora os locais de teste dos dois mapas de Tucson fossem similares, o mapa produzido pela rede neural foi visualmente mais precisa; esta diferença pode ser explicada pelo exame das regiões das classes e pelos pontos de densidade no espaço de decisão e pelos valores contínuos produzidos pelos dois classificadores. Para a cena de Oakland, os dois 
mapas eram visualmente e numericamente similares, embora a rede neural fosse superior na supressão dos erros de pixels misturados na classificação. Por essa análise, chegou-se a conclusão que a rede neural é mais robusta para locais de treinamento heterogêneos e para classificação de usos de solo com misturas de assinaturas espectrais. A diferença entre os dois algoritmos pode ser vista, em parte, como a diferença entre classificadores paramétricos (máxima verossimilhança) e não paramétricos (rede neural). Computacionalmente, a classificação realizada através de redes neurais retroalimentadas apresenta desvantagens em relação à classificação por máxima verossimilhança, tomando mais tempo para a realização dos processamentos computacionais do que a máxima verossimilhança quando implementados em uma workstation serial.

Outros trabalhos que utilizam redes neurais para o mapeamento do uso do solo urbano incluem: BERBEROGLU, et. al (2000), JARVIS e STUART (1996), KUMAR et al (1997).

\section{Classificação fuzzy ou classificação soft}

A lógica fuzzy é uma técnica usada em alguns sistemas especialistas para representar valores reais fracionários entre os estados verdadeiro e falso da computação binária normal. A lógica difusa pode expressar um resultado como um estado intermediário, de modo que ele seja mais preciso - por exemplo, "pode ser verdadeiro" ou “provavelmente verdadeiro". (TEIXEIRA e CHRISTOFOLETTI, 1997).

Segundo SCHOWERGERDT (1996), os algoritmos de classificação convencionais que definem uma só classe para um pixel ignoram o fato de que muitos pixels em imagens de sensoriamento remoto representam predominância das assinaturas espectrais de duas ou mais categorias nas superfícies. A mistura de assinaturas é devido à mistura natural da maioria das categorias de cobertura do solo da natureza, o contínuo físico que pode existir entre as legendas de categorias discretas, reamostradas pela retificação geométrica, e pela integração espacial definida pela função de propagação do ponto do sensor.

Uma classificação rígida ("hard”) é produzida selecionando aquela classe com a maior probabilidade de estar correta. A borda do espaço de decisão das feições para uma classificação rígida é bem definida. Se os valores de probabilidade são retidos, 
entretanto, permitindo múltiplas classes para cada pixel, uma classificação relativa (“soft”) é obtida. A limite/fronteira do espaço de decisão das feições para uma classificação relativa pode ser dita como mal definida, ou fuzzy. (SCHOWERGERDT, 1996)

Em geral, os métodos da classificação reduzem a dimensionalidade de uma série de dados complexos agrupando-os em um conjunto de classes.

Nos métodos tradicionais de classificação, cada elemento da amostra é colocada em uma classe ou outra. Na classificação tradicional, o elemento da classe é binário, uma amostra é um elemento de uma classe ou não. $\mathrm{O}$ valor do elemento da classe pode ser "1" quando essa é a classe na qual melhor se ajusta, ou "0" (para todas as classes restantes).

BROWN (1998), identifica a classificação fuzzy como apropriada para dados com 1) “ambigüidade de atributos"; 2) quando há "imprecisão/incerteza espacial". A ambigüidade do atributo ocorre quando o elemento da classe é parcial ou não claro. A imprecisão espacial surge quando a resolução da amostra não é clara o bastante para definir as posições dos limites, quando as transições graduais ocorrem entre classes, ou quando há alguma incerteza da posição nos dados.

De acordo com FOODY (2000), os dados de sensoriamento remoto são uma fonte atrativa de dados de cobertura do solo sob uma larga escala espacial e temporal. A concretização do potencial total do sensoriamento remoto como uma fonte de dados da cobertura do uso do solo é, entretanto, restringido por inúmeros fatores. Um problema comum é a presença de pixels misturados, que não são apropriadamente acomodados nas técnicas de classificação convencional usados nos mapas temáticos de dados de sensoriamento remoto. Este problema tem sido resolvido através da adoção de classificação fuzzy ou soft. Neste tipo de classificação, a intensidade da relação entre os elementos, um pixel mostrado como pertencente a uma classe, é utilizada como um substituto para uma cobertura fracional daquela classe. A precisão da representação da cobertura do uso do solo resultante é, entretanto, dependente do relacionamento entre o peso do elemento da classe e a cobertura fracional da classe associada. Como o elemento da classe é mensurado em relação à classe definida no estágio de treinamento da classificação, classes não treinadas podem influenciar na 
precisão da estimação da composição da classe. Por exemplo, um pixel representando uma área de uma classe não treinada pode somente mostrar elementos das classes treinadas. O efeito de uma classe não treinada na estimação da composição das classes dos sub-pixels irá depender de como o peso do elemento da classe foi calculado.

FOODY e ARORA (1996), realizam uma classificação em três estágios: através de máxima verossimilhança, redes neurais e classificação fuzzy. Classificadores supervisionados convencionais não acomodam pixels misturados diretamente mas pode ser modificado através do processo de classificação. Os pixels misturados foram incluídos nos três estágios de classificação por máxima verossimilhança e redes neurais. Os resultados mostraram que, pela acomodação de pixels misturados na classificação, saídas mais acuradas, apropriadas e úteis podem ser produzidas.

\section{Análise de textura de imagens}

Segundo ZHANG (1999), métodos de análise de textura são freqüientemente utilizados para o reconhecimento e distinção de diferentes características espaciais em imagens digitais. Na execução da análise de textura, os relacionamentos entre os valores de cinza do pixel corrente e os pixels próximos a ele são calculados com base em uma certa medida de textura (média, desvio padrão, contraste, correlação, energia, entropia, etc.). Os valores de cinza da imagem de saída representam o critério de textura local da imagem de entrada.

O contexto de um pixel refere-se a sua relação espacial com qualquer outro pixel ou grupos de pixels através da toda a cena (GURNEY e TOWSHEN, apud CAMPOS, 2002). A Textura é uma medida contextual que pode ser extraída de uma janela $\mathrm{n} x \mathrm{n}$ e então adicionada ao conjunto de imagens originais antes da classificação (PEDDLEY e CURRAN, 1991 apud CAMPOS, 2002).

MOLLER-JENSEN (1990), desenvolveu uma metodologia de classificação de imagens de satélite usando sistemas inteligentes com a incorporação de informações de textura e de contexto bem como as características de reflectância. O artigo descreve o desenvolvimento de uma metodologia utilizando sistemas inteligentes para a produção de mapas de uso do solo em áreas urbanas baseados em informações espectrais, texturais e de contexto em imagens LANDSAT TM. O propósito geral 
deste estudo é estabelecer uma base para examinar o potencial de uso das imagens de satélite como uma fonte de informação para o mapeamento do uso do solo no contexto do planejamento urbano, especialmente para o terceiro mundo onde a expansão espacial das cidades principais faz o uso das imagens de satélites desejável.

As fotografias aéreas, que foram as primeiras fontes de informação de áreas urbanas, são superiores às imagens de satélite em termos de resolução espacial. A maior desvantagem, entretanto, é o custo muito alto por unidade de área, e a interpretação visual (feita manualmente), o que para grandes cidades, é uma arefa de considerável volume, envolvendo o trabalho de um grupo de pessoas por muitos meses. Há o risco da variação de interpretação entre os intérpretes, produzindo assim, resultados de classificação não homogêneos. Por outro lado, o formato digital das imagens de satélite torna possível o uso de algoritmos de classificação automáticos ou semiautomáticos, com a utilização da informação de todas as bandas espectrais disponíveis de uma vez. As imagens de satélite, então, permitem um melhor entendimento das tendências de desenvolvimento nas grandes cidades do terceiro mundo, com possibilidades de rápida atualização das informações espaciais, detecção de mudanças e visualização de resultados.

Segundo OLMO e HERNANDEZ (2000), a maioria dos algoritmos matemáticos clássicos para classificação de imagens não considera a dependência espectral existente entre o pixel e seus vizinhos, isto é, a autocorrelação espacial. Assim, é aconselhável para a discriminação das classes de cobertura do solo, a adição, nas bandas radiométricas do sensor, informações complementares relativas às feições de textura de uma imagem, a qual pode ser analisada através da estrutura de autocorrelação espacial dos números digitais. Desta maneira, os resultados obtidos dos classificadores pixel a pixel que levam em conta simultaneamente informações radiométricas e de textura podem ser incrementados. Este incremento vem da hipótese que o pixel não é independente de seus vizinhos, e ainda, que sua dependência pode ser quantificada e incorporada no classificador. No artigo de OLMO e HERNANDEZ (2000), foi apresentada uma metodologia baseada em computar um conjunto de medidas de textura univariadas e multivariadas de variabilidade espacial baseada em diversos estimadores de variogramas (função que mede a variabilidade de uma medida em função da distância). 
No estudo de ATKINSON e LEWIS (2000), os variogramas têm sido utilizados para representar formalmente a dependência espacial em imagens de sensoriamento remoto e usados em classificação de textura no lugar dos filtros simples de variâncias.

ZHANG (1999), utilizou técnicas de textura para detecção de edificações urbanas em dois estágios. O primeiro estágio é uma classificação multiespectral convencional. No segundo estágio, a classificação das edificações é incrementada por meio das informações espaciais através de uma matriz de co-ocorrência modificada. A dependência da direção na matriz de co-ocorrência é utilizada no processo de filtragem. O método foi testado usando dados de uma imagem TM e SPOT para toda a área da cidade de Shangai, China. Depois da filtragem com a matriz de coocorrência, a exatidão média do usuário aumentou cerca de $46 \%$ e a média da estatística Kappa cerca de 15\%. Este resultado é cerca de $26 \%$ melhor que a precisão alcançada pelos filtros de textura normal. O método apresentado no estudo de ZHANG (1999) é muito útil para uma estimação rápida de edificações urbanas e desenvolvimento da cidade, especialmente em áreas metropolitanas para países em desenvolvimento.

GONG e HOWARTH (1990), utilizaram um método para incorporação de informações de estruturas nos procedimentos de classificação de imagens convencional. Os autores utilizaram dados do sensor HRV multiespectral do satélite SPOT para a identificação da franja urbana-rural em Toronto no Canadá. Para isso utilizaram filtros passa alta em uma das bandas da imagem para a identificação das bordas entre as áreas urbanas e rurais. Esta banda foi utilizada no processo de classificação convencional como uma banda adicional. Os resultados mostraram uma melhora na diferenciação entre as classes de uso do solo que possuíam assinaturas espectrais semelhantes e um aumento na acurácia da classificação.

Outros estudos urbanos com a utilização de texturas incluem: MOLLER-JENSEN (1997); BERBEROGLU et al. (2000); FRANKLIN et al (1996); STUCKENS et al. (2000). 
Os métodos de classificação multiespectral convencionais tem sido utilizado com sucesso para detecção de objetos em imagens de satélite. Entretanto, eles ainda são problemáticos para a detecção de classes de objetos em áreas urbanas.

Os motivos são: 1) os objetos nas áreas urbanas são muito complexos. Eles são caracterizados mais pela sua estrutura do que suas propriedades espectrais. 2) métodos de classificação convencional extraem classes de objetos somente de acordo com as informações espectrais dos pixels individuais, enquanto uma grande quantidade de informação espacial é negligenciada. (ZHANG, 1999).

Diversos estudos de áreas urbanas pelos métodos convencionais. Entre eles: STEELE (2000); HSU, 1978 apud ZHANG, 1999; GONG et al 1990 apud ZHANG, 1999; HARRIS et al, 1995 apud ZHANG 1999; BARNSLEY et al, 1996 apud ZHANG, 1999.

\section{Sistemas inteligentes (Expert system).}

Outras técnicas de sucesso para a melhoria da precisão da classificação tem sido a incorporação de outras fontes de dados na classificação ou a pós classificação, referido a partir de agora como os sistemas inteligentes ("Expert system”).

Sistemas inteligentes permitem a integração de dados de sensoriamento remoto com outras fontes de informações georreferenciadas como dados de uso do solo, texturas espaciais, modelos de elevação digital para obter aumento na precisão da classificação. Regras de decisões lógicas são usadas com vários conjuntos de dados para determinar os valores das classes para cada pixel.

STEFANOV et al. (2001), utilizou dados de reflectância do sensor TM do LANDSAT, adquiridos em 1998 (bandas visível ao infravermelho curto mais índices de vegetação) que foram inicialmente classificadas para a cobertura do solo utilizando classificação supervisionada por máxima verossimilhança. Um sistema inteligente foi construído para executar a pós classificação da classificação de cobertura do solo iniciais usando os dados espaciais como as texturas, e informações adicionais como leis de uso do solo, áreas de proteção dos mananciais, limite das cidades. Os pixels foram reclassificados, e a acurácia global da técnica foi de $85 \%$. A 
maior vantagem dos sistemas inteligentes é a flexibilidade a respeito das fontes de dados e potencial de aplicação às diversas questões.

HARRIS e VENTURA (1995) utilizaram informações de zoneamento e densidade de construção para executar a classificação pós-classificação de uma classificação inicial por máxima verossimilhança com dados TM da Beaver Dam, da área de Wisconsin.

VOGELMAN et al (1998) incorporaram índices de vegetação derivados de sua base de dados TM, junto com diversas séries de dados subordinados, para produzir uma classificação da cobertura do solo final de uma região de 30 milhões de ha nos Estados Unidos.

GREENBERG e BRANDLEY (1997) utilizaram informações de população e densidade de estradas com dados TM para classificar cobertura do solo em Seatle, área de WA.

STUCKENS et al. (2000) produziu uma classificação de cobertura do solo de Minneapolis-St. Paul, área urbana de MN utilizando dados TM com uso da terra subordinado e inventários de Wetland .

\section{Outros estudos}

Outros estudos identificam as áreas urbanas através das ilhas de calor. ANIELLO et al. (1995), utilizou dados de satélite LANDSAT TM e software SIG para mapear micro-ilhas urbanas de calor em Dallas, Texas. As micro-ilhas urbanas de calor são localizações urbanas isoladas que produzem "pontos de calor" dentro da cidade. Uma classificação não supervisionada foi executada em uma imagem LANDSAT para extração das coberturas arborizadas que foram fundidas com dados da banda 6 TM (termal), compondo um mapa mostrando a localização das micro ilhas urbanas de calor e áreas arborizadas.

Os resultados indicaram que a presença de micro ilhas urbanas de calor eram resultantes da falta de cobertura de árvores relacionadas a novos empreendimentos residenciais, pátios de estacionamento, distritos de negócios, complexos de apartamentos, e shopping centers. Todas as micro ilhas urbanas de calor eram naturalmente radiativas, com altas temperaturas no centro. 
Imagens de satélite são utilizadas também para a criação de índices de qualidade de vida em assentamentos como visto em LO (1997) que utilizou variáveis sócioeconômicas de dados de censo, integradas através de ferramentas GIS para demonstrar a qualidade de vida, e FORSTER apud LO (1997) que utilizou dados de reflectância espectral derivados de imagens LANDSAT MSS na cidade de Sydney, Austrália para desenvolver índices de qualidade residencial, utilizando as dimensões das casas e os índices de vegetação como indicadores positivos de qualidade e rodovias e construções não residenciais como indicadores negativos. $\mathrm{O}$ valor das casas é fortemente ligado à dimensão da residência, FORSTER apud LO (1997) demonstrou que os valores das casas de Sydney podem ser previstos através de dados LANDSAT em áreas extensas. 


\section{4 ÁREA DE ESTUDO}

Com o interesse da Prefeitura do Município de São Bernardo do Campo em encontrar soluções eficientes para problemas do uso do solo na região, foi realizado um convênio com o Laboratório de Geoprocessamento da USP, que em conjunto com os técnicos do Departamento de Planejamento Estratégico da Prefeitura do Município de São Bernardo do Campo, desenvolveram métodos de mapeamento da ocupação do uso do solo através de imagens de sensoriamento remoto e técnicas de processamento digital de imagens.

Um dos objetivos deste convênio foi a transferência da tecnologia de processamento digital de imagens de sensoriamento remoto aos técnicos da prefeitura, para que esta fosse posteriormente divulgada e implantada à prefeitura, através de manuais e treinamentos. Durante 16 meses, os técnicos da prefeitura receberam o treinamento que envolvia desde os conceitos teóricos de sensoriamento remoto, técnicas de processamento digital de imagens e exercícios práticos de processamento digital. $\mathrm{O}$ software utilizado para isso foi o IDRISI3.2, de fácil entendimento e manuseio. Os técnicos aplicaram as técnicas aprendidas numa área conhecida (o município de São Bernardo do Campo). Estas técnicas de processamento digital de imagens de satélite foram transferidas aos técnicos da prefeitura à medida que a metodologia se desenvolvia. O conhecimento da área de estudo pelos técnicos, auxiliou muito nos trabalhos. Foi utilizado também o levantamento aerofotogramétrico realizado pela Prefeitura para a verificação da verdade de campo. Parte dos resultados obtidos deste projeto faz parte dos resultados práticos obtidos nesta dissertação. Outros resultados obtidos deste projeto foram os manuais e apostilas que os técnicos desenvolveram contendo os conceitos teóricos e os resultados práticos. Um dos produtos gerados deste projeto foi um artigo "Technology transfer in digital image processing techniques" apresentado no International IT Conference on Geo Spatial Education, Hong Kong em 2000. Mais detalhes sobre este projeto de transferência de tecnologia pode ser visto em QUINTANILHA et al.(2000b).

A metodologia desenvolvida para o mapeamento do uso do solo na região do Município de São Bernardo do Campo através de imagens de satélite, procura conciliar as técnicas de processamento digital das imagens de sensoriamento remoto 
com as necessidades da Prefeitura no monitoramento das regiões ocupadas no município.

Para a elaboração de uma legenda que suprisse as necessidades da prefeitura, as classes a serem analisadas foram definidas a partir de três considerações: as classes de uso do solo definidas pela lei de uso do solo do município ou pela legislação de uso do solo, as classes possíveis de serem observadas nas imagens através de processamento digital das imagens orbitais e a distribuição das classes na realidade.

Basicamente, três classes foram consideradas importantes: as áreas urbanas, as áreas vegetadas (Mata Atlântica) e a represa.

\subsection{A região de estudo}

A região de estudo é o Município de São Bernardo do Campo. Esta região foi escolhida, pois nas últimas décadas, observou-se um processo de crescimento urbano intenso e rápido, com a conurbação do município central com os municípios vizinhos, ocasionando a ocupação desordenada do espaço físico e a invasão das áreas protegidas por lei (áreas de proteção aos mananciais hídricos, áreas de reserva florestal) e devido à inexistência de estudos na linha de interesse deste projeto na área selecionada. "Conurbação, é a fusão de duas ou mais áreas urbanizadas ou aglomerados urbanos". (FERRARI, 1988).

A localização da área de estudo é apresentada na Figura 11.

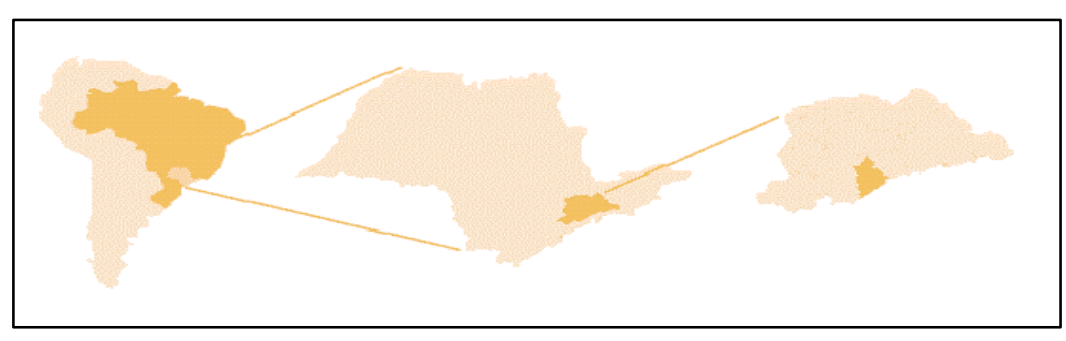

Figura 11 - Brasil, América do Sul / Estado de São Paulo, Região Metropolitana de São Paulo / Região Metropolitana de São Paulo, São Bernardo do Campo. 


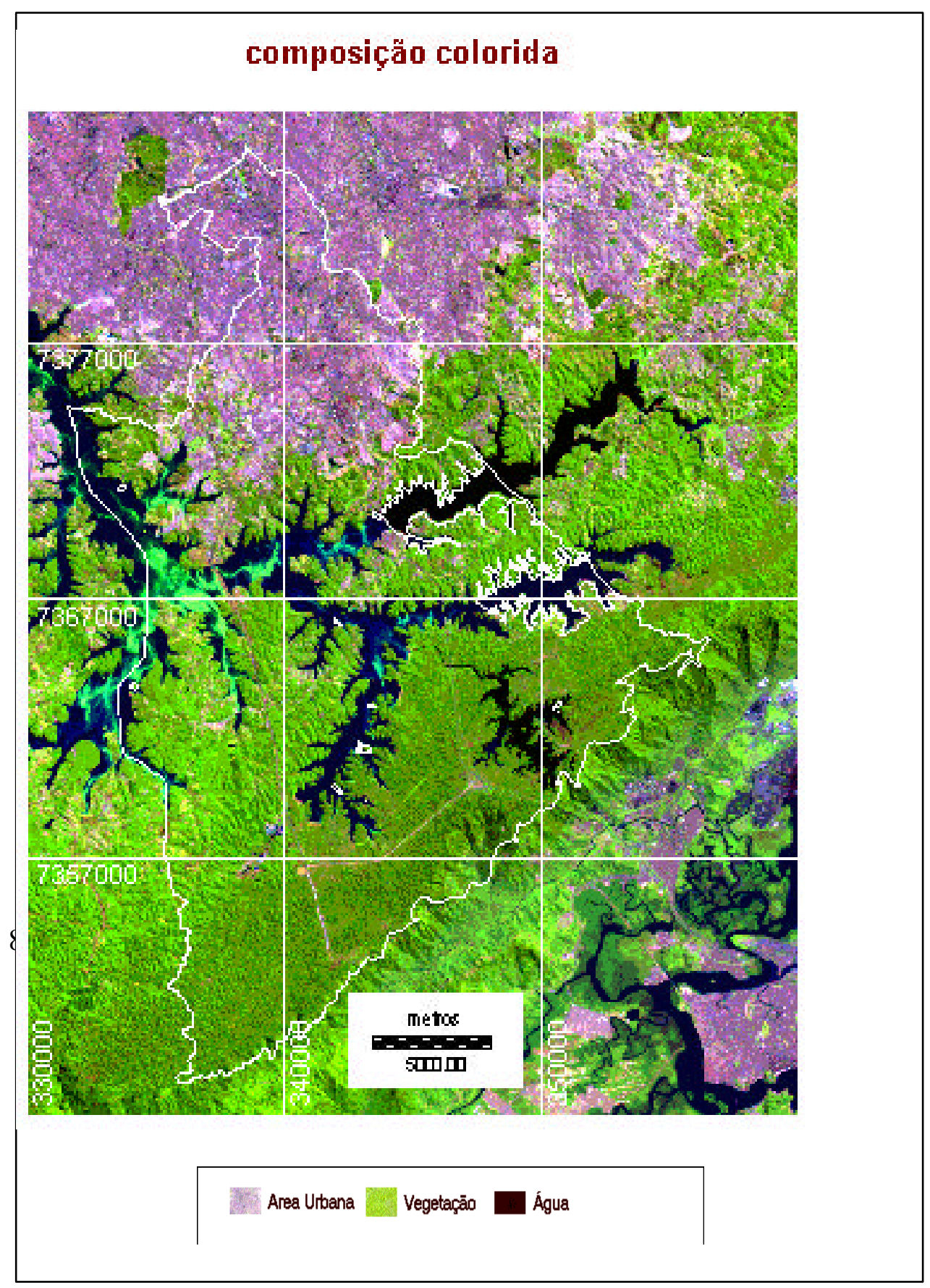

Figura 12 - Imagem LANDSAT7 ETM+, composição colorida 3B4G5R, setembro 1999, órbita ponto 219-076, 219-077

São Bernardo do Campo é um município situado na região metropolitana de São Paulo, e sua extensão territorial é de $407.1 \mathrm{Km}^{2}$, sendo que $75.82 \mathrm{Km}^{2}$ (cerca de 18.6\%) correspondem à área ocupada pela represa Billings, que é formada pelo represamento das águas do Rio Grande e seus afluentes e pelas águas da Bacia do 
Rio das Pedras em sua parte do Planalto, 118,74 $\mathrm{Km}^{2}$ (cerca de 29,2\%) correspondem à área urbana (indústria, comércio, residências) e 212,54 $\mathrm{Km}^{2} \quad(52,2 \%)$ à área rural (chácaras). (PREFEITURA DO MUNICÍPIO DE SÃO BERNARDO DO CAMPO, 1998) (Figura 12).

É delimitada uma região em torno da represa que representa a área de proteção aos mananciais hídricos correspondente a uma área de 212,94 $\mathrm{Km}^{2}(52,3 \%)$. Esta área corresponde às áreas ao redor da represa Billings, às áreas de reservas florestais da Mata Atlântica e ao Parque Estadual da Serra do Mar (PREFEITURA DO MUNICÍPIO DE SÃO BERNARDO DO CAMPO, 1998).

\subsection{Processo de urbanização da região de estudo}

Para se entender o processo de urbanização na região de estudo é necessário sua inserção no contexto nacional.

Segundo a SECRETARIA DO MEIO AMBIENTE et al. (1999), o processo de urbanização no Brasil teve início a partir de meados do século XX. Em 1950, sua população rural era de 33 milhões de habitantes e a urbana de 19 milhões. A partir de 1970 a população urbana sextuplicou, situando-se hoje em mais de 120 milhões, enquanto que a população rural alcançou um máximo de 41 milhões e vem diminuindo.

Segundo dados do IBGE no último censo realizado o Brasil, em 2000, 138 milhões de pessoas vivem nas áreas urbanas, enquanto que 32 milhões vivem nas áreas rurais, totalizando 170 milhões de habitantes.

A urbanização no Brasil só começa a existir de fato quando a indústria tornou-se o setor mais dinâmico da economia, fato que só ocorre plenamente no século XX.

Até então, predominavam as atividades econômicas ligadas às atividades primárias: o açúcar (séculos XVI e XVII), a mineração (século XVIII), o café (de meados do século XIX até início do XX), entre outras, o que mantinha um equilíbrio quase estável entre a população urbana e a população rural. As atividades dos setores 
secundários (indústrias) e terciários (principalmente comércio e administração) praticamente inexistiam.

Com o início da industrialização, a urbanização se intensifica, aumentando também a oferta de emprego no setor terciário (bancos, comércio, escolas, seguros, etc), atraindo ainda mais a população para os centros das cidades.

Assim, a porcentagem da população urbana sobre o total da população brasileira passa a ser progressiva: 36\% em 1950, 45\% em 1960, 76\% em 1991, 78\% em 1996 e $81 \%$ em 2000 (Tabela 7).

Tabela 7 - População urbana e rural no Brasil (1950-2000) (milhares)

\begin{tabular}{|c|c|c|c|c|c|c|c|}
\hline Ano & 1950 & 1960 & 1970 & 1980 & 1991 & 1996 & 2000 \\
\hline $\begin{array}{c}\text { Popul. } \\
\text { Urbana }\end{array}$ & 18.782 & 32.004 & 52.905 & 82.013 & 110.875 & 123.082 & 137.954 \\
\hline $\begin{array}{c}\text { Popul. } \\
\text { Rural }\end{array}$ & 33.161 & 38.987 & 41.603 & 39.137 & 36.041 & 33.997 & 31.845 \\
\hline Total & 51.944 & 70.992 & 94.508 & 121.150 & 146.917 & 157.079 & 169.799 \\
\hline
\end{tabular}

Fonte: IBGE (2002).

Na década de 70, o crescimento de grandes cidades ocorre em todas as regiões do País, caracterizando o processo de metropolização no Brasil. Em 1973 foram criadas oficialmente as primeiras regiões metropolitanas do Brasil: São Paulo, Rio de Janeiro, Belo Horizonte, Salvador, Fortaleza, Recife, Porto Alegre, Curitiba e Belém (EMPLASA, 2003).

A partir da década de 80, observam-se alterações no processo de urbanização brasileiro, com tendências de crescimento das cidades menores. As grandes cidades apesar de exibirem concentração econômica e demográfica expressiva no contexto do país e taxas de crescimento significativas, de modo geral apresentam crescimento populacional menos acelerado, conforme pode ser observado na Tabela 8 e na Figura 13. A Tabela 8 mostra o crescimento populacional das principais regiões metropolitanas do país no período de 1991 a 2000. Pela Tabela 8, observa-se que as cidades de São Paulo e Rio de Janeiro apresentam quantidade de população residente bem superiores aos das outras cidades. No entanto, estas cidades apresentaram nos últimos anos (entre 1991 e 2000 da Tabela 8), taxas de crescimento menores que as de outros estados (Figura 13). 
Tabela 8 - População residentes nas principais regiões metropolitanas brasileiras

\begin{tabular}{|c|c|c|c|c|}
\hline & \multicolumn{4}{|c|}{ População Residente (em 1.000) } \\
\hline $\begin{array}{c}\text { Regiões } \\
\text { Metropolitanas } \\
(1)\end{array}$ & $1991(2)$ & $1996(3)$ & $1997(4)$ & $2000(5)$ \\
\hline Belém & 1.401 & 1.574 & 1.619 & 1.796 \\
\hline Fortaleza & 2.307 & 2.583 & 2.650 & 2.985 \\
\hline Recife & 2.920 & 3.088 & 3.130 & 3.338 \\
\hline Salvador & 2.497 & 2.709 & 2.759 & 3.022 \\
\hline Belo Horizonte & 3.436 & 3.803 & 3.890 & 4.819 \\
\hline Vitória & 1.065 & 1.182 & 1.212 & 1.426 \\
\hline Rio de Janeiro & 9.815 & 10.192 & 10.287 & 10.894 \\
\hline São Paulo & 15.445 & 16.583 & 16.860 & 17.879 \\
\hline Curitiba & 2.058 & 2.425 & 2.504 & 2.727 \\
\hline Porto Alegre & 3.028 & 3.247 & 3.301 & 3.658 \\
\hline
\end{tabular}

Fonte: IBGE, Censo Demográfico de 1991, Contagem da População, 1996 e estimativas da população para Estados e Municípios, 1997, publicadas no Diário Oficial da União de 28.08.1997. Elaboração: EMPLASA, 1997.

(1) Regiões Metropolitanas, segundo as estruturas territoriais vigentes em 1997.

(2) População residente em 1 o de setembro.

(3) População residente em 10 de agosto

(4) População residente em 10 de julho.

(5) Censo de 2000, IBGE

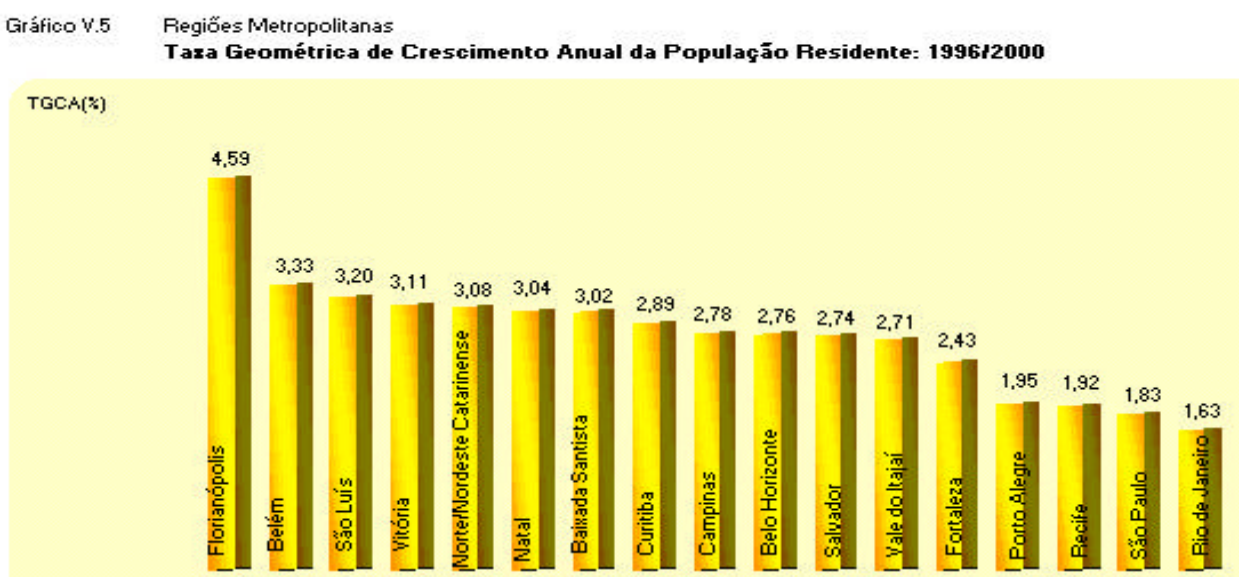

Fonte: IEGE; Contsgem do Populş̧́⿴囗十 de 1996 × Dsdoe Preliminares do Censo Demográfico de 2000

Elsborsç5o: Emplocs,2000

Figura 13 - Taxa geométrica de crescimento anual da população residente

Fonte: IBGE elaborado pela EMPLASA (2002a). 
Segundo BERNARDES (2003), a principal tendência do processo de urbanização brasileiro é a participação decrescente das regiões metropolitanas na população do país, com crescimento acelerado das cidades médias (municípios com população em torno de 100 mil habitantes).

"A participação das cidades médias na população do pais tem aumentado nos últimos anos. A quantidade de municípios com população entre 200 mil e 500 mil passou de 35 para 85; municípios com mais de 500 mil aumentou de 14 para 25; e as aglomerações milionárias passou de 10 para 12” (BERNARDES, 2003).

Segundo BERNARDES (2003), cidades milionárias são cidades que polarizam grandes parcelas do contingente populacional urbano e que, na prática, se caracterizam como regiões metropolitanas, como Brasília, Goiânia, Manaus, Santos e Campinas.

“Em 1980 havia apenas quatro cidades com mais de meio milhão de habitantes, fora as nove regiões metropolitanas oficiais - São Paulo, Rio de Janeiro, Belém, Fortaleza, Recife, Salvador, Belo Horizonte, Porto Alegre e Curitiba. Atualmente, municípios com população entre 500 mil e 1,5 milhão de habitantes incluem importantes centros urbanos como Brasília, Manaus, Campinas, São Luís, Maceió, Natal, Teresina, Campo Grande e Goiânia.” (BERNARDES, 2003).

Esta tendência tem provocado maior distribuição da população no sistema urbano.

Segundo SECRETARIA DO MEIO AMBIENTE el al. (1999), diversas razões levaram a desaceleração no ritmo de concentração nas áreas metropolitanas: a desconcentração industrial e sua interiorização, o impacto da crise de 80 sobre o movimento migratório e o próprio êxodo rural e a queda da taxa de fecundidade, entre outros fatores. 


\subsection{A expansão urbana na RMSP}

A participação do Município de São Paulo (MSP) na contagem da população no Estado de São Paulo e no Brasil é expressiva. (Tabela 9). Durante muitos anos o Estado de São Paulo e o Município de São Paulo, vêm atraindo migrantes para a região, concentrando uma parcela significativa na população brasileira na região (em 2000, correspondia a $21,8 \%$ da população brasileira).

Tabela 9 - População residente e taxas de crescimento anual (1980-2000)

\begin{tabular}{|c|c|c|c|c|}
\hline Local & \multicolumn{4}{|c|}{ População residente } \\
\hline Brasil & 1980 & 1991 & 1996 & 2000 \\
\hline $\begin{array}{c}\text { Estado de São } \\
\text { Paulo }\end{array}$ & 25.040 .712 & 31.588 .925 & 34.120 .886 & 37.032 .403 \\
\hline RMSP & 12.588 .725 & 15.444 .941 & 16.583 .234 & 17.834 .664 \\
\hline $\begin{array}{c}\text { Município de São } \\
\text { Paulo - MSP }\end{array}$ & 8.493 .226 & 9.646 .185 & 9.839 .436 & 10.405 .867 \\
\hline $\begin{array}{c}\text { Participação do } \\
\text { MSP na RMSP }\end{array}$ & $67,5 \%$ & $62,5 \%$ & $59,3 \%$ & $58,3 \%$ \\
\hline $\begin{array}{c}\text { Participação do } \\
\text { Estado de SP no } \\
\text { Brasil }\end{array}$ & $21,0 \%$ & $21,5 \%$ & $21,7 \%$ & $21,8 \%$ \\
\hline
\end{tabular}

Fonte: EMPLASA (2002b).

Porém nos últimos anos, o Município de São Paulo - MSP vem apresentando uma redução expressiva na participação da taxa de crescimento populacional em relação à Região Metropolitana de São Paulo - RMSP, como pode ser observado na Tabela 10 e na Figura 14.

Segundo a SECRETARIA DO MEIO AMBIENTE et al. (1999), a desconcentração industrial foi uma das responsáveis pela redução da migração. Além disso, outros fatores como a redução da taxa de fecundidade e natalidade afetaram o crescimento demográfico. 


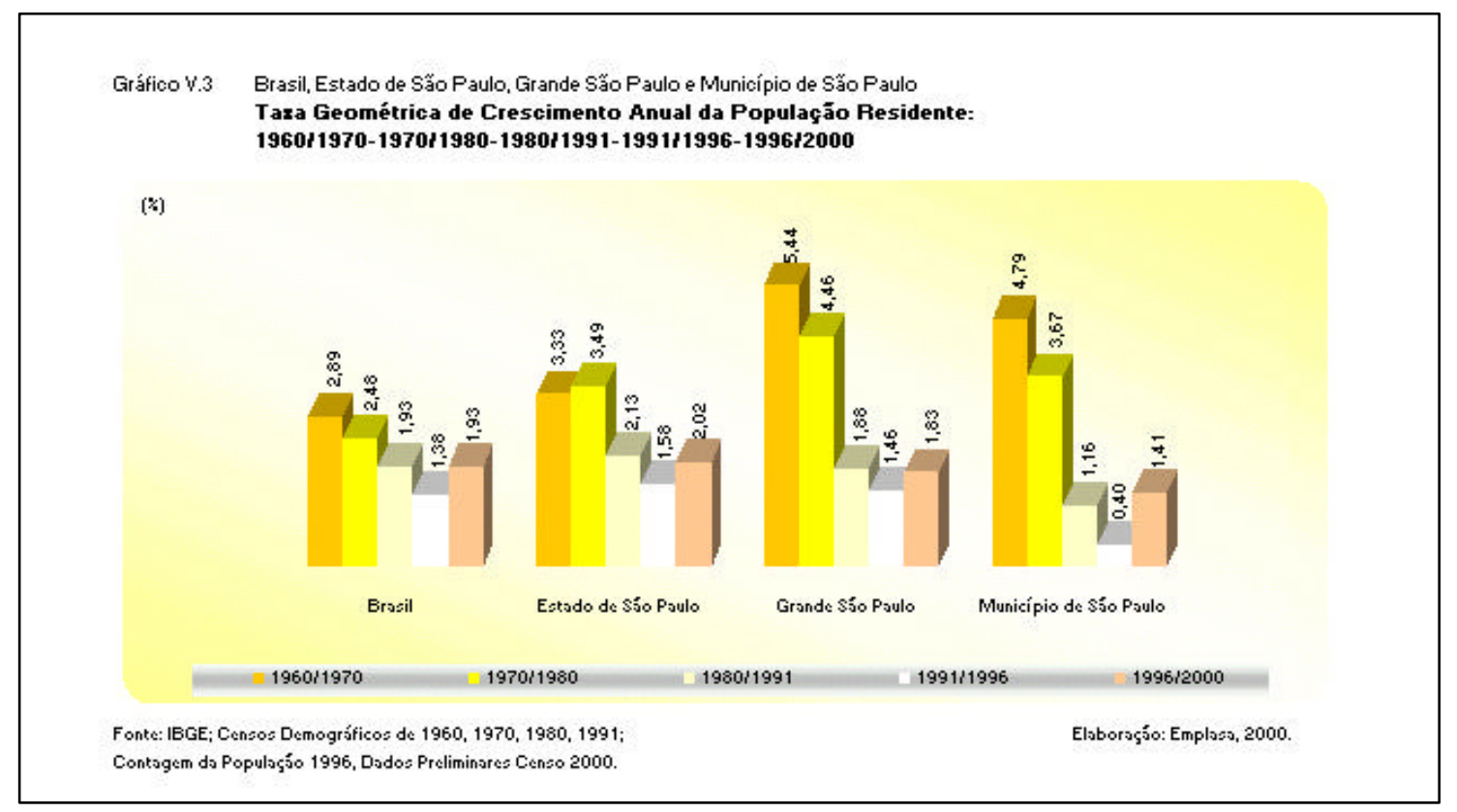

Figura 14 - Taxa geométrica de crescimento anual da população residente

Fonte: EMPLASA (2002c).

Tabela 10 - Taxa de crescimento anual da população residente (\%)

\begin{tabular}{|c|c|c|c|c|c|}
\hline & \multicolumn{5}{|c|}{ Taxa de crescimento anual da população residente (\%) } \\
\hline & $1960 / 1970$ & $1970 / 1980$ & $1980 / 1991$ & $1991 / 1996$ & $1996 / 2000$ \\
\hline Brasil & 2,89 & 2,48 & 1,93 & 1,38 & 1,930 \\
\hline $\begin{array}{c}\text { Estado de São } \\
\text { Paulo }\end{array}$ & 3,33 & 3,49 & 2,13 & 1,58 & 2,02 \\
\hline Grande são Paulo & 5,44 & 4,46 & 1,88 & 1,46 & 1,83 \\
\hline $\begin{array}{c}\text { Município de São } \\
\text { Paulo }\end{array}$ & 4,79 & 3,67 & 1,16 & 0,40 & 1,41 \\
\hline
\end{tabular}

Fonte: EMPLASA (2002c).

Segundo TAGNIN (2000), uma das causas apontadas para a redução do crescimento populacional é a queda do componente migratório regional, que se tornou negativo a partir dos anos 80. Segundo este autor, é possível apontar expressivos movimentos migratórios, tanto no sentido da região, como no sentido da emigração, que se subdivide em três principais correntes: dirigidas para dentro da própria região, para o interior e para os estados de origem.

Dessas três correntes, a mais expressiva e a de maior interesse é a intra-metropolitana que tem levado habitantes das classes sociais de menor renda e de alta renda (baixa 
densidade) a buscarem outras alternativas de moradia, configurando a expansão física da urbanização que se observa na região.

Os segmentos sociais de renda mais baixa buscam alternativas ao preço elevado dos terrenos e imóveis construídos da cidade, buscando localizações mais periféricas e/ou outros municípios da região metropolitana.

Ainda segundo TAGNIN (2000), observa-se que, associado aos movimentos de expansão e de crescimento nas áreas periféricas, há uma redução das taxas de crescimento e diminuição da população nas áreas centrais das cidades.

Outra característica importante dessa década, foi a intensificação de dois elementos: o da dispersão dos migrantes entre diferentes destinos e para locais mais distantes da periferia da região e o da multiplicação das suas origens, já que provém, cada vez mais de diversos sub-centros mais periféricos em relação à capital.

Segundo diversos autores, entre eles, TAGNIN (2000) e SECRETARIA DO MEIO AMBIENTE et al. (1999), as principais causas do processo migratório atual são: a crise econômica e o agravamento da pobreza, a deterioração das condições de vida nas áreas mais centrais, o mercado de terras e a valorização contínua das áreas urbanas, entre outros elementos centrados nas condições sociais e no mercado imobiliário.

Quanto aos movimentos migratórios da população de renda mais elevada, estes são devidos à deterioração das condições de vida nos maiores centros: aumento da violência, dificuldades de trânsito, a poluição, bem como a oferta crescente de opções imobiliárias na periferia da RMSP. De forma geral, atribui-se também à desconcentração das atividades produtivas os elevados níveis de mobilidade intrametropolitana.

Segundo TAGNIN (2000), um dos importantes fatores apresentados para a expansão urbana é a espera da valorização das áreas melhor localizadas e atendidas nos centros das cidades e regiões intermediárias, pelo investimento público na criação de infraestrutura e serviços por alguns investidores. 
Esse processo, leva a população de menor renda aos locais mais distantes, precários e de menor custo relativo, fazendo com que a periferia da mancha urbana avance para as áreas mais frágeis e de proteção ambiental, principalmente sobre as áreas dos mananciais metropolitanos.

De acordo com a SECRETARIA DO MEIO AMBIENTE et al. (1999), a periferização das camadas mais pobres da população se dá através da implantação de inúmeros loteamentos clandestinos e do surgimento de favelas em fundos de vale, desprovidos de equipamentos e infra-estrutura urbanos necessários a uma adequada qualidade de vida da população e dos recursos hídricos existentes.

Conforme a Tabela 11, observa-se a taxa decrescente da população nos centros urbanos e o crescimento populacional nas zonas Leste 2 e a Norte 1, periféricas. Pode-se observar também, que o crescimento do número de domicílios foi superior ao crescimento da população no mesmo período.

Tabela 11 - Crescimento da população e dos domicílios permanentes ocupados no Município de São Paulo (1980-1991)

\begin{tabular}{|c|c|c|}
\hline Regiões & $\begin{array}{c}\text { População \% de crescimento } \\
\text { anual 80/91 }\end{array}$ & $\begin{array}{c}\text { Domicílios \% de } \\
\text { crescimento anual 80/91 }\end{array}$ \\
\hline Centro histórico & $-1,16$ & 1,35 \\
\hline Centro expandido & $-0,86$ & 4,39 \\
\hline Oeste & 2,34 & 40,61 \\
\hline Sul & 2,14 & 35,22 \\
\hline Sudeste & 0,49 & 15,27 \\
\hline Leste 1 & 0,27 & 12,23 \\
\hline Leste 2 & 3,81 & 64,78 \\
\hline Norte 1 & 2,28 & 39,68 \\
\hline Norte 2 & 0,44 & 14,55 \\
\hline Município de São Paulo & 1,16 & 23,17 \\
\hline
\end{tabular}

Fonte: FIBGE; Censo Demográfico 80 e 91 (SECRETARIA DO MEIO AMBIENTE et al., 1999)

Segundo TAGNIN (2000), esse crescimento é creditado ao aumento no número de favelas e loteamentos precários ou o adensamento dos existentes.

Segundo SECRETARIA DO MEIO AMBIENTE et al. (1999), um aspecto que talvez seja mais importante do que o crescimento populacional é o aumento do 
número de domicílios. No Brasil, dois fatores contribuem para a geração de um déficit habitacional acentuado. Por um lado, o processo de urbanização e concentração populacional nas regiões metropolitanas, associado à especulação imobiliária, a propriedade do solo e a valorização dos terrenos. A escassez de moradias e a falta de condições econômicas da população migrante, foram propulsoras do crescimento de favelas e da expansão horizontal das grandes cidades. Por outro lado, as mudanças na estrutura familiar têm feito com que os domicílios sejam ocupados por um número cada vez menor de pessoas. Fatores como o divórcio e a saída de casa dos filhos, levam à necessidade de ocupação de um número maior de domicílios. Em termos de economia de escala, além da disponibilização de serviços públicos, esse crescimento acentuado do número de domicílios é altamente impactante.

Os empreendimentos imobiliários para a classe média com menor poder aquisitivo, dirigem-se para áreas pior atendidas por serviços e infra-estruturas do que nas áreas centrais. Apesar de apresentarem menor valor dos que os localizados nas áreas centrais, são muito mais caros do que os ofertados nas mesmas regiões, contribuindo para a valorização dos imóveis, terrenos vazios e aluguéis desses bairros, estimulando a transformação de unidades habitacionais em comércio e provocando a saída dos moradores mais pobres. (SECRETARIA DO MEIO AMBIENTE et al., 1999).

As relações de trabalho também passam por transformações, com o aumento do desemprego e o aumento de trabalhos informais, sem carteira assinada. Esses trabalhos informais ganham espaço, reduzindo o volume de contribuições passíveis de utilização em políticas previdenciárias ou redistributivas e a renda dos trabalhadores. (SECRETARIA DO MEIO AMBIENTE et al., 1999).

Assim, verifica-se a redução nos índices de crescimento demográfico na RMSP, a expansão urbana na periferia e o esvaziamento populacional das áreas centrais. $\mathrm{O}$ que ocorre na RMSP, é um processo de expulsão da população de menor renda para locais compatíveis com a sua condição sócio-econômica para construção de suas moradias, não se tratando, efetivamente, de expansão por necessidade de espaço físico para abrigar novos habitantes. 


\section{O Município de São Bernardo do Campo}

A partir de meados da década de 30, a crescente valorização do solo nas áreas mais centrais da cidade de São Paulo, juntamente com o desenvolvimento do transporte ferroviário, favoreceu a implantação de novas indústrias nas áreas vizinhas da capital paulista, como o Santo André, São Bernardo do Campo, São Caetano, Guarulhos e Osasco, prosseguindo nos anos 40 e se acentuando nas décadas de 50 e 60, com o desenvolvimento da indústria automobilística e do transporte rodoviário, favorecendo particularmente o eixo do ABC paulista. (SECRETARIA DO MEIO AMBIENTE et al., 1999).

O desenvolvimento do Município de São Bernardo do Campo foi favorecido pela proximidade com a cidade de São Paulo (16,5 km em linha reta) e a posição geográfica (o município localiza-se entre São Paulo e o litoral). O município observou um grande crescimento econômico e populacional nas últimas décadas.

Outros fatores contribuíram para o desenvolvimento da região. O município é atravessado por duas grandes rodovias, a Rodovia Anchieta (inaugurada nos anos 40) e a Imigrantes, que são passagens obrigatórias para o escoamento de produtos a serem exportados de São Paulo e que ligam o Estado de São Paulo ao Porto de Santos; a proximidade de Usinas Hidrelétricas, como por exemplo, a Henry Borden de Cubatão, que fornecem energia elétrica para a região; a existência de grandes espaços não construídos ao longo da rodovia que favorece a instalação de indústrias de grande porte; os recursos hídricos e a possibilidade de mão de obra abundante.

Durante o Governo Kubitschek (1956-1960), a região ganha impulso com a implantação de grandes montadoras do setor automobilístico (Ford, Mercedez, Volkswagen, Scania) ao longo da Rodovia Anchieta e o desenvolvimento de outras indústrias com funções complementares, como a produção de autopeças, de borracha, e as indústrias mecânica, metalúrgica e química (SECRETARIA DO MEIO AMBIENTE et al., 1999).

Depois, outras indústrias se instalaram na região como a Nestlé. Estas indústrias atraíram muitos migrantes para a região devido à oferta de empregos, acarretando crescimento populacional intenso e a expansão urbana. 
O desenvolvimento econômico e industrial do Município de São Bernardo do Campo foi acompanhado por um crescimento populacional intenso e contínuo: a população do município, que era de cerca 29 mil habitantes em 1950, chegou a aproximadamente 723 mil habitantes em 1999, tendo crescido quase 25 vezes em 50 anos (Tabela 12).

Tabela 12 - Crescimento vegetativo e migratório no município de São Bernardo do Campo

\begin{tabular}{|c|c|c|c|c|c|c|}
\hline \multirow[t]{2}{*}{ ANO } & \multirow[t]{2}{*}{ POPULAÇÃO } & \multirow{2}{*}{$\begin{array}{c}\text { TAXA CRESC. } \\
\text { ANUAL } \%\end{array}$} & \multicolumn{2}{|c|}{ PARTICIPAÇÃO \% } & \multicolumn{2}{|c|}{ TAXA CRESC. ANUAL \% } \\
\hline & & & VEGET. & MIGRAT. & VEGET. & MIGRAT. \\
\hline 1950 & 29.295 & - & - & - & - & - \\
\hline 1960 & 81.255 & 10,74 & 30,73 & 69,27 & 4,45 & 8,34 \\
\hline 1970 & 201.662 & 9,52 & 29,28 & 70,72 & 3,67 & 7,43 \\
\hline 1980 & 425.602 & 7,76 & 38,69 & 61,31 & 3,64 & 5,33 \\
\hline 1991 & 566.893 & 2,64 & 83,20 & 16,80 & 2,24 & 0,49 \\
\hline 1996 & 660.396 & 3,10 & 48,99 & 51,01 & 1,57 & 1,63 \\
\hline $1999 *$ & $\begin{array}{l}723.132 \\
\text { *estimativa }\end{array}$ & 3,07 & 48,39 & 51,61 & 1,51 & 1,61 \\
\hline
\end{tabular}

Fonte: MUNICÍPIO DE SÃO BERNARDO DO CAMPO (2002).

Enquanto que o Estado de São Paulo e a Grande São Paulo apresentam redução das taxas geométricas de crescimento - nos períodos 1980/91 é de 2,13\%, em 1991/96 é de $1,55 \%$ e 1996/2000 é de 1,41\% (Figura 15), o município de São Bernardo do campo apresenta crescentes taxas de crescimento anual (Figura 15), contrariando a tendência que se observa na Grande ABC.

Grande parte desse crescimento se deve às migrações, que ainda apresentam uma participação significa no crescimento populacional do município, como pode ser 
observado na Tabela 12. Entre os anos de 1996 e 1999, 51\% do crescimento populacional neste período se deve às migrações.

\section{EVOLUÇÃO DA POPULAÇÃO}
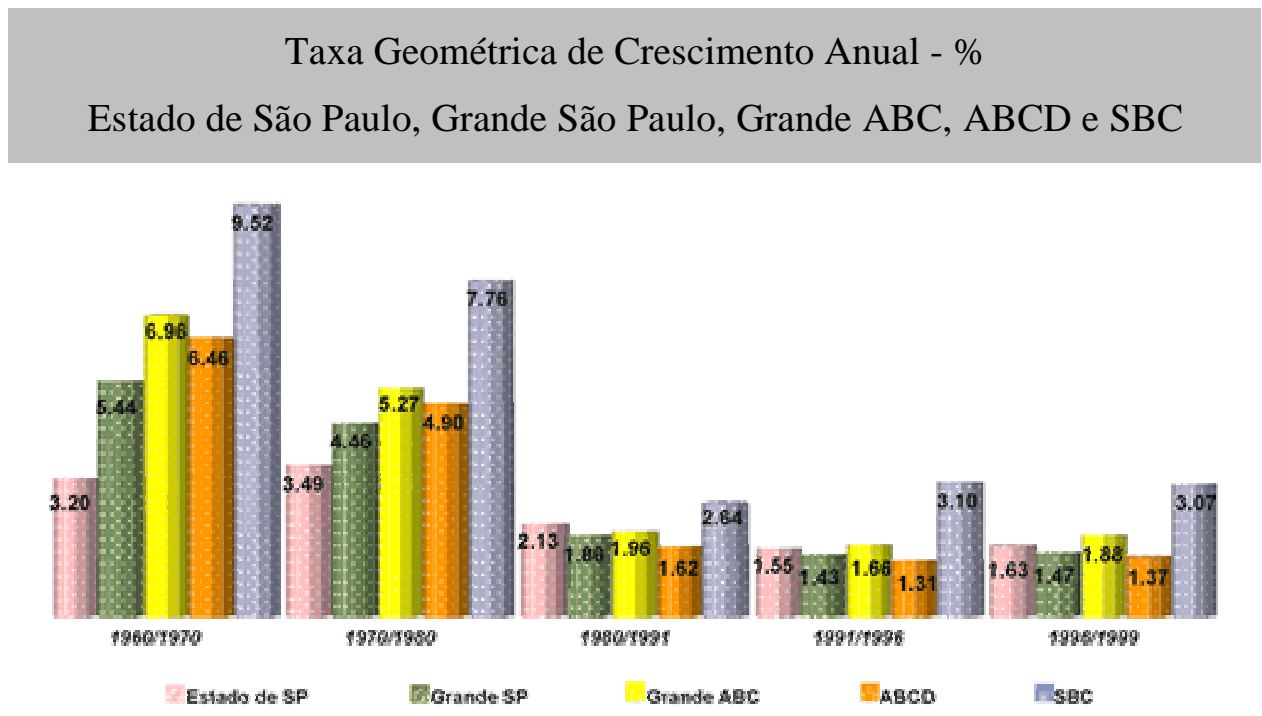

Figura 15 - Taxa geométrica de crescimento anual

\section{Fonte: MUNICÍPIO DE SÃO BERNARDO DO CAMPO (2002).}

O crescimento populacional ocasionado pela desenvolvimento industrial intenso saturam as áreas centrais do município. Com a saturação das áreas centrais e as altas taxas geométricas de crescimento anual (Figura 15), o crescimento urbano pode estar se direcionando para a zona de mananciais.

O adensamento populacional do município de São Bernardo do Campo, pode ser observado pela Tabela 13, que mostra a densidade populacional no município de São Bernardo do Campo no período de 1980 a 1996. Em 1980, a densidade populacional no município de São Bernardo do Campo era de 1035,53 hab/km2, passando para 1377,93 hab/km2 em 1991, chegando a 1598,82 hab/km2 em 1996, variando 54,4\% de 1980 a 1996, como se observa na Tabela 13. 
Tabela 13 - Área dos municípios da região da Bacia Billings, densidade demográfica e variação da densidade demográfica no período 1980/1996.

\begin{tabular}{|c|c|c|c|c|c|c|c|}
\hline \multirow[t]{2}{*}{ REGIÃO } & \multicolumn{2}{|c|}{1980} & \multicolumn{2}{|c|}{1991} & \multicolumn{2}{|c|}{1996} & \multirow{2}{*}{$\begin{array}{l}\text { Variação da } \\
\text { Densidade } \\
\text { no período } \\
\text { 1980/96(\%) }\end{array}$} \\
\hline & $\begin{array}{l}\text { Área } \\
(\mathrm{Km} 2)\end{array}$ & $\begin{array}{l}\text { Densidade } \\
\text { (hab/Km2) }\end{array}$ & $\begin{array}{l}\text { Área } \\
\text { (Km2) }\end{array}$ & $\begin{array}{r}\text { Densidade } \\
(\mathrm{hab} / \mathrm{Km} 2)\end{array}$ & $\begin{array}{l}\text { Área } \\
\text { (Km2) }\end{array}$ & $\begin{array}{l}\text { Densidade } \\
\text { (hab/Km2) }\end{array}$ & \\
\hline $\begin{array}{l}\text { Estado de São } \\
\text { Paulo } \\
\end{array}$ & 248600 & 100,73 & 248600 & 126,90 & 248600 & 136,81 & 35,8 \\
\hline Diadema & 32 & 7145,63 & 32 & 9533,38 & 32 & 10090,88 & 41,2 \\
\hline Mauá & 67 & 3070,75 & 67 & 4397,48 & 67 & 5130,99 & 67,1 \\
\hline Ribeirão Pires & 107 & 528,34 & 107 & 794,72 & 107 & 935,09 & 77,0 \\
\hline $\begin{array}{l}\text { Rio Grande da } \\
\text { Serra } \\
\end{array}$ & 31 & 648,16 & 31 & 962,84 & 31 & 1118,77 & 72,6 \\
\hline Santo André & 181 & 3055,65 & 181 & 3398,41 & 181 & 3453,88 & 13,0 \\
\hline $\begin{array}{c}\text { São Bernardo do } \\
\text { Campo }\end{array}$ & 411 & 1035,53 & 411 & 1377,93 & 411 & 1598,82 & 54,4 \\
\hline $\begin{array}{c}\text { São Caetano do } \\
\text { Sul }\end{array}$ & 12 & 13590,17 & 12 & 12433,58 & 12 & 11745,92 & $-13,6$ \\
\hline São Paulo & 1509 & 5628,38 & 1509 & 6379,65 & 1509 & 6500,30 & 15,5 \\
\hline \begin{tabular}{|c|} 
Total dos \\
Municípios da \\
região da Bacia \\
Billings \\
\end{tabular} & 2350 & 4307,55 & 2350 & 4957,21 & 2350 & 5133,42 & 19,2 \\
\hline
\end{tabular}

Fonte: SECRETARIA DO MEIO AMBIENTE et al. (1999).

Estudos realizados por MARCONDES (1995), mostram a expansão de áreas urbanizadas e de superfície de loteamentos aprovados em áreas de mananciais em alguns municípios entre os anos de 1974 e 1980, indicando alto grau de clandestinidade ou da irregularidade que ocorrem nestas regiões, como pode ser observado nas Tabelas 14 e 15.

A ocorrência de favelas vem aumentando em ritmo superior ao do crescimento da população dessa bacia e além da característica precariedade para seus moradores, seus reflexos na qualidade das águas do reservatório são mais acentuados pela concentração de grandes contingentes populacionais, em densidades muito superiores àquelas verificadas nas zonas urbanas mais verticalizadas do Município de São Paulo (SECRETARIA DO MEIO AMBIENTE et al., 1999). 
Tabela 14 - Expansão de área urbanizada e superfície de loteamentos aprovados em áreas de mananciais para alguns municípios (1974-1980).

\begin{tabular}{|c|c|c|}
\hline Município & $\begin{array}{c}\text { Superfície de loteamentos } \\
\text { aprovados (ha) }\end{array}$ & $\begin{array}{c}\text { Expansão da área } \\
\text { urbanizada (ha) }\end{array}$ \\
\hline São Paulo & 115,4 & 2544 \\
\hline $\begin{array}{c}\text { São Bernardo do } \\
\text { Campo }\end{array}$ & 281,5 & 584 \\
\hline Embu & $-\cdot-----$ & 356 \\
\hline Mairiporã & 186,4 & 1224 \\
\hline
\end{tabular}

Fonte: MARCONDES (1995).

Tabela 15 - Densidades habitacionais em favelas na Bacia Billings (1996)

\begin{tabular}{|c|c|c|c|c|c|}
\hline & & & \multicolumn{3}{|c|}{ Densidade da população favelada } \\
\hline Município & $\begin{array}{c}\text { População } \\
\text { total na } \\
\text { bacia }\end{array}$ & $\begin{array}{c}\text { População } \\
\text { favelada na } \\
\text { bacia Billings }\end{array}$ & $\begin{array}{c}\text { Média } \\
\text { aritmética } \\
\text { das } \\
\text { densidades } \\
\text { (hab/ha) }\end{array}$ & $\begin{array}{l}\text { Densidade } \\
\text { média geral } \\
\text { (hab/há) }\end{array}$ & $\begin{array}{l}\text { Densidade } \\
\text { máxima } \\
\text { verificada } \\
\text { (hab/ha) }\end{array}$ \\
\hline São Paulo & 371.822 & $\begin{array}{c}80.474(70 \\
\text { favelas })\end{array}$ & 592,88 & 449,93 & $\begin{array}{l}3340,98 \\
\text { (área de } \\
0,61 \mathrm{ha} \text { ) }\end{array}$ \\
\hline $\begin{array}{c}\text { São } \\
\text { Bernardo } \\
\text { do Campo }\end{array}$ & 158.328 & $\begin{array}{c}29.673(21 \\
\text { favelas) }\end{array}$ & 782,42 & 497,79 & $\begin{array}{c}2.296,73 \\
\text { (área de } 1,53 \\
\text { ha) }\end{array}$ \\
\hline $\begin{array}{l}\text { Santo } \\
\text { André }\end{array}$ & 23.653 & $\begin{array}{l}\text { 2.942(1 } \\
\text { favela) }\end{array}$ & 668,64 & 668,64 & $\begin{array}{c}668,64 \\
\text { (área de } 4,40 \\
\text { ha) }\end{array}$ \\
\hline $\begin{array}{l}\text { Ribeirão } \\
\text { Pires }\end{array}$ & 77.662 & 422 (1 favela) & 107,11 & 107,11 & $\begin{array}{c}107,11 \\
\text { (área de } 3,94 \\
\text { ha) }\end{array}$ \\
\hline Diadema & 49.967 & $\begin{array}{c}7.636(14 \\
\text { favelas) }\end{array}$ & 429,24 & 383,72 & $\begin{array}{c}\text { 687,16 (área } \\
\text { de } 1,48 \text { ha) }\end{array}$ \\
\hline Total & 681.432 & $\begin{array}{c}121.147 \text { (107 } \\
\text { favelas) }\end{array}$ & 604,84 & 381,07 & $\begin{array}{c}3.340,96 \\
\text { (área de } 0,61 \\
\text { ha) }\end{array}$ \\
\hline
\end{tabular}

Fonte: SMA/CPLA, com base nos dados da contagem da população 1996 IBGE (SECRETARIA DO MEIO AMBIENTE et al., 1999). 
Segundo dados da SECRETARIA DO MEIO AMBIENTE et al. (1999), a população total residente na bacia em 1991 foi estimada em 534 mil habitantes, sendo 429 mil habitantes nas áreas urbanas (80,3\%) e 30 mil habitantes nas áreas rurais (5,6\%). Cerca de $14,1 \%$ da população residiam em favelas. Em 1996, a população residente na bacia foi estimada em 711 mil habitantes, sendo $79 \%$ da população em áreas urbanas, $15,9 \%$ favelada e 5,1\% rural (Tabela 16).

Tabela 16 - Acréscimo Populacional 91/96, na Bacia Billings, por municípios.

\begin{tabular}{|c|c|c|c|c|c|c|c|}
\hline Município & \multicolumn{2}{|c|}{ Censo 1991 } & \multicolumn{2}{c|}{ Censo 1996 } & \multicolumn{3}{c|}{ Acréscimo 91/96 } \\
\hline & Habitantes & $\%$ & Habitantes & $\%$ & Habitantes & $\%$ & Taxa Anual \\
\hline & & & & & & & \\
\hline São Paulo & 262087 & 49 & 371822 & 51 & 109735 & 42 & 7,2 \\
\hline Diadema & 44556 & 8 & 49967 & 8 & 5412 & 12 & 2,3 \\
\hline São Bernardo & 114613 & 20 & 158328 & 22 & 43715 & 38 & 6,7 \\
\hline Santo André & 17518 & 3 & 23653 & 4 & 6134 & 35 & 6,2 \\
\hline Ribeirão Pires & 69309 & 14 & 77662 & 11 & 8353 & 12 & 2,3 \\
\hline $\begin{array}{c}\text { Rio Grande da } \\
\text { Serra }\end{array}$ & 26338 & 5 & 29534 & 5 & 3196 & 12 & 2,3 \\
\hline TOTAL & 534421 & 100 & 710965 & 100 & 176544 & 33 & 5,8 \\
\hline
\end{tabular}

Fonte: SECRETARIA DO MEIO AMBIENTE et al. (1999).

A taxa média de crescimento populacional anual na bacia foi de 5,8\%, sendo que o crescimento populacional no Município de São Paulo dentro da bacia foi de 7,2\% ao ano (Tabela 16), taxas bastante superiores àquelas verificadas para o conjunto da Região Metropolitana $(1,46 \%)$ e para o próprio Município de São Paulo $(0,40 \%)$ (Tabela 11).

Por fim, a expansão sobre os mananciais permite observar seu enquadramento nas características gerais do padrão verificado em países pobres e em desenvolvimento, cuja motivação na fase atual da RMSP, não decorre do rápido crescimento populacional promovido pela migração das áreas rurais e sim de transformações importantes no meio urbano da própria região, envolvendo, sobretudo, populações de baixa renda (TAGNIN, 2000).

O crescimento populacional desordenado em uma bacia hidrográfica utilizada para abastecimento público, como é o caso da Billings, influencia diretamente a sua 
qualidade ambiental. Quanto maior o número de habitantes, maiores são as possibilidades de impactos ambientais como a impermeabilização do solo e a remoção da cobertura vegetal para a construção de moradias, além de contaminação da água através do lançamento de esgoto e da disposição inadequada de lixo. (CAPOBIANCO et al, 2000).

A invasão às áreas de mananciais que ocorre no município de São Bernardo do Campo é feita de maneira extremamente agressiva ao meio ambiente e de forte impacto ambiental.

A invasão se inicia com o desmatamento das florestas para a construção da moradia. Sem proteção da vegetação, ocorre a erosão e conseqüente assoreamento dos rios. Com a densificação das moradias, o lixo acumulado e o esgoto acabam poluindo as águas dos rios e da represa.

Os problemas ambientais nas áreas protegidas, o crescimento descontrolado da ocupação urbana, a taxa de crescimento populacional alta, a falta de fiscalização, a mudança do perfil econômico da cidade e a inerente dinâmica urbana das áreas metropolitanas levaram o governo local a definir uma política efetiva de monitoramento do uso do solo em São Bernardo do Campo.

Com o objetivo de minimizar esses impactos, a legislação de proteção aos mananciais da RMSP, estabelecida na década de 70, definiu limites de densidades populacionais para estas regiões. As áreas passíveis de ocupação foram divididas em três classes, sendo que para cada uma delas foram adotados tamanhos de lotes e taxas de ocupação máximas permitidas.

Ao longo dos anos, entretanto, o incremento populacional na bacia hidrográfica da Billings, ocorreu de forma bem diferente do previsto na legislação. No período de 1991 a 1996, a região recebeu 178 mil novos habitantes, representando um crescimento populacional de 33,13\% em apenas cinco anos. (Tabela 17). 
Tabela 17 - Crescimento da população residente na Bacia, por município, no período 1991-1996 ${ }^{(*)}$

\begin{tabular}{|c|c|c|}
\hline \multirow{2}{*}{ Município } & \multicolumn{2}{|c|}{ Acréscimo 91-96 } \\
\cline { 2 - 3 } & habitantes & $\%$ (obs.) \\
\hline Diadema & 5.411 & 12,14 \\
\hline Ribeirão Pires & 8.353 & 12,05 \\
\hline Rio Grande da Serra & 4.888 & 16,38 \\
\hline Snato André & 6.135 & 35,02 \\
\hline São Bernardo do Campo & 43.715 & 38,14 \\
\hline São Paulo & 109.735 & 41,87 \\
\hline Total & 178.237 & 33,13 \\
\hline
\end{tabular}

(*) Censos demográficos IBGE 1980 e 1991 e Contagem Populacional 1996 (SMA/1996)

(obs.) Em relação à população residente na Bacia, por município, em 1991.

Fonte : CAPOBIANCO et al. (2002).

Além de extremamente acelerada, a ocupação da região vem ocorrendo sem nenhum planejamento e está intimamente ligada às dinâmicas recentes de expansão urbana da região metropolitana de São Paulo, em que as áreas centrais estão perdendo população para as áreas mais periféricas.

\subsection{A Lei de proteção aos mananciais}

As áreas de proteção aos mananciais da Região Metropolitana de São Paulo abrangem, total ou parcialmente, vinte e seis municípios da RMSP (a RMSP integra trinta e nove municípios), correspondendo a cerca de 54\% do total da região e foram instituídas por intermédio de legislação específica em meados da década de 70.

Os recursos hídricos dos mananciais da RMSP são disputados pelos diversos usos e com regiões vizinhas que se encontram em crescimento. A relação entre o consumo e a disponibilidade se dá de forma aguda, pois como se situam em cabeceiras de drenagem, concentram as principais demandas urbanas e industriais do Estado e apresentam grande comprometimento qualitativo de suas águas.

A represa Billings, o maior reservatório de águas da Região Metropolitana de São Paulo, foi construído pela Light, entre 1927 e 1937, como parte do sistema hidrelétrico do Alto Tietê, com a finalidade de geração de energia. A demanda por 
energia elétrica foi priorizada durante muitos anos pelas lideranças políticas, empresariais e principalmente pela população que ansiava por empregos e desenvolvimento, em detrimento da preservação da qualidade das águas da represa Billings. Em 1951, com o início das atividades da elevatória de Traição iniciou-se o bombeamento massivo das águas poluídas dos rios Tietê e Pinheiros para o reservatório a fim de aumentar a geração de energia na Usina de Cubatão. Este sistema permaneceu intocável por mais de 60 anos, provocando a degradação do maior manancial da Grande São Paulo.

Com a poluição das águas da represa, houve a desvalorização dos lotes situados às margens da represa, afastando formas de ocupação compatíveis com a proteção dos mananciais, como os clubes recreativos e as chácaras e, ao mesmo tempo, estimulando a ocupação de loteamentos clandestinos, parcelamentos irregulares, invasões e favelas. As ocupações realizadas de forma predatória agravaram ainda mais as condições gerais dos reservatórios d'água. O desmatamento das florestas para a construção de moradias causa a erosão do solo e assoreamento dos rios. Sem infra-estrutura, o esgoto e o lixo são lançados diretamente nos rios e córregos deteriorando ainda mais as condições sanitárias e ambientais dos reservatórios.

Além disso, há riscos de desabamento e inundação nestas regiões, que geralmente não são adequadas para construção de moradias.

A Lei de Proteção aos Mananciais foi promulgada em 1976 pelo governo estadual com o intuito de proteger a Bacia Hidrográfica da Represas Billings, impedindo a ocupação desordenada destas áreas (recebeu ampla revisão através da lei n.o 9866 de 28/11/97), não sendo capaz, porém, de prevenir e conter ocupação predatória das áreas sob proteção.

Os instrumentos de proteção aos mananciais instituídos neste período coincidem com a intensificação das demandas de água - da diluição de esgotos ao abastecimento da população. Estes instrumentos tentam impedir ou regularizar a expansão urbana nas áreas de mananciais. 
Estes instrumentos foram o Plano Metropolitano de Desenvolvimento Integrado PMDI, que lançou as bases para a gestão metropolitana de diversos campos de atuação setorial desse território, incluindo o da proteção de seus recursos hídricos; a Legislação de Proteção aos Mananciais - LPM, originada das propostas do PMDI e dotada de um abrangente aparato de proteção, até então inédito na região e, a Lei Estadual de Proteção aos Mananciais - 9866/97, nascida após vinte anos de vigência da LPM, com o intuito de revê-la, apesar de ter uma abrangência maior que a dos mananciais da RMSP.

\section{PLANO METROPOLITANO DE DESENVOLVIMENTO INTEGRADO - PMDI}

Esse plano é reconhecido como a primeira expressão de um planejamento mais amplo do crescimento urbano na metrópole, que inclui a proteção aos mananciais como uma de suas recomendações fundamentais, através do tratamento integrado de aspectos territoriais, sociológicos, econômicos e infra-estruturais.

O PMDI foi elaborado em 1971, pelo Grupo Executivo da Grande São Paulo GEGRAN, encarregado de traçar diretrizes de planejamento metropolitano, que contemplavam a reorientação das tendências de crescimento e desenvolvimento urbano regional, a partir das quais estruturou-se uma série de instrumentos, como a própria legislação de proteção aos mananciais. (TAGNIN apud MARCONDES, 1995).

O plano apontou, dentre suas diretrizes para a metrópole, as de:

- Orientar a expansão do aglomerado metropolitano na direção Leste-Oeste e no sentido Nordeste - onde se oferecem as condições mais propícias à ocupação urbana - e restringir o crescimento nas direções Sul e Sudeste, a fim de proteger seus recursos hídricos e recreacionais.

- Preservar as represas Billings, Guarapiranga e as dos Sistemas Cantareira e Alto Tiete da poluição e da ocupação urbana de suas bacias, através de Legislação Estadual de controle de uso do solo na Área Metropolitana. 
- Promover um sistema integrado metropolitano de grandes espaços abertos, a fim de:

○ Proteger os recursos hídricos;

- Criar áreas de recreação ativa;

- Preservar a paisagem regional;

- Criar ampla reserva de espaços públicos para o futuro.

- Preservar da poluição os recursos hídricos da região e as áreas de sua influência, bem como controlar e reduzir a poluição dos cursos d'água afetados, recuperando-os para fins mais nobres.

- Considerar o Saneamento nos planos de desenvolvimento da região como fator decisivo, dadas às peculiaridades da área e a relativa escassez de recursos hídricos para atendimento das elevadas concentrações industriais e demográficas.

- Estabelecer uma política quanto ao uso dos recursos hídricos da região que dê prioridades ao abastecimento e à recreação (GREGORI; ZULAUF; NUCCI, 1976 apud TAGNIN, 2000)

De acordo com SECRETARIA DO MEIO AMBIENTE ET AL., 1992 apud TAGNIN, 2000, a partir dos anos 70, a expansão urbana observada nos vetores sudoeste, sul e sudeste da área metropolitana representou uma alteração das diretrizes traçadas pelo PMDI, com dinâmica e adensamento mais reduzidos do que se esperava. A principal proposta do PMDI contudo, propunha claramente a reorientação do crescimento urbano para fora das áreas de mananciais.

\section{LEGISLAÇÃO DE PROTEÇÃO AOS MANANCIAIS - LPM}

A legislação de proteção aos mananciais, estabelece critérios para o uso e ocupação do solo das áreas protegidas, em função da preservação de um nível mínimo de 
qualidade da água bruta dos mananciais, permitindo torná-la potável mediante tratamento convencional. (SECRETARIA DO MEIO AMBIENTE et al., 1999).

Contempla tanto os aspectos de natureza preventiva - ao estimular usos da água e do solo adequados e restringir aqueles que representam risco a potabilização dos mananciais; como de natureza corretiva - por adotar medidas destinadas a adaptar a ocupação já existente aos novos parâmetros legais e estabelecer procedimentos para, por exemplo, a implantação de saneamento básico e remoção de lixo (SECRETARIA DO MEIO AMBIENTE et al., 1999).

Para o estabelecimento das atividades e tipos de ocupações permitidas, portanto, pesaram fatores relativos à qualidade das águas, como o tipo e o nível de tratamento dos efluentes e resíduos gerados, o grau de concentração espacial dessas atividades, a sua distância em relação aos corpos d'água; bem como aqueles referentes à manutenção do regime das águas, que implicaram no estabelecimento de limites à impermeabilização do solo, para evitar a erosão e o assoreamento dos mananciais superficiais e para possibilitar a recarga dos lençóis d'água.

Outro princípio dessa legislação a ser destacado constitui em reconhecer os direitos adquiridos da população que já ocupava algumas áreas da bacia dos mananciais antes de seu advento, prevendo a possibilidade de alguma expansão urbana ou adensamento preferencialmente em torno desses núcleos já consolidados. (SECRETARIA DO MEIO AMBIENTE et al., 1999).

Foi a primeira legislação de proteção de recursos hídricos a utilizar instrumentos de controle de uso e ocupação do solo (MOREIRA, 1990). Nas bacias que abrangeu, ela distingue duas categorias de proteção $\left(1^{\mathrm{a}}\right.$ e $\left.2^{\mathrm{a}}\right)$, estabelecendo uma série de normas para cada uma delas.

As áreas de $1^{\mathrm{a}}$ categoria são aquelas consideradas prioritárias para proteção, por envolverem as porções do território mais importante para assegurar as características desejáveis para os mananciais, tais como: 
- Áreas mais próximas aos corpos d'água, sob a forma de faixas de largura variável, dependendo de estarem contíguas a reservatórios $(50 \mathrm{~m})$, a fluentes primários (20m) e aos demais cursos d'água $(5 \mathrm{~m})$;

- Áreas com cota inferior a $1,5 \mathrm{~m}$ do nível máximo dos reservatórios, situadas nas suas proximidades;

- Áreas de matas e;

- Áreas com declividade superior a $60 \%$.

Nessas áreas, a possibilidade de ocupação restringe-se aos usos recreacionais e esportivos da água, sem a presença de instalações permanentes. Da mesma forma, a implantação de infra-estrutura limita-se a serviços, obras e edificações destinados à proteção dos mananciais, à regularização de vazões, ao controle de cheias e ao uso da água para o abastecimento.

As áreas de $2^{\mathrm{a}}$ categoria correspondem ao restante do território das bacias e são subdivididas em três classes, em ordem crescente de restrições quanto à ocupação:

- Classe A, constituídas por ocupações com densidade superior a 30 hab/ha e crescimento previsto até 50 hab/ha, abrigam os núcleos urbanos pré-existentes à legislação;

- Classe $\mathrm{B}$, envoltórias das de classe $\mathrm{A}$, e com dimensão proporcional à delas e à distância que as separa das faixas de $1^{\text {a }}$ categoria, destinam-se à expansão das ocupações pré-existentes, com densidades máximas de ocupação prevista entre 25 e 34 hab/ha e;

- Classe C, compreendem as demais áreas, constituídas de zonas rurais ou de baixa densidade de ocupação - entre 6 e 24 hab/ha.

Nessas áreas (classes A, B e C), são permitidos praticamente todos os tipos de usos urbanos, além daqueles ligados ao lazer, horticultura, silvicultura e extração vegetal, sob determinadas condições como, por exemplo: 
- Uso industrial - restrito a uma relação expedida pelo órgão ambiental de controle;

- Uso comercial - exceto o varejista;

- Uso institucional - exceto hospitais, sanatórios e equipamentos de saúde, ressalvados os destinados ao atendimento local, desde que não especializados em doenças transmissíveis;

- Uso agrícola - devendo respeitar mrmas de proteção e conservação de solos e de uso de fertilizantes e defensivos.

Quanto às condições de ocupação, destacam-se as seguintes restrições:

- Os índices urbanísticos - área de lotes, densidades de ocupação, taxa de ocupação dos terrenos, coeficientes de aproveitamento e índice de elevação que são determinados de acordo com a classe da área, sendo mais restritivos para a Classe C;

- É exigida a manutenção nos lotes de $20 \%$ a $40 \%$ de sua área sem impermeabilização;

Para a definição desses usos e formas de ocupação, foi utilizado como indicador básico a carga de poluição potencialmente gerada por seus habitantes, ou ocupantes, expressa em DBO - Demanda Bioquímica de Oxigênio.

Essa carga foi fixada de forma a não superar os limites pré-estabelecidos de qualidade da água do manancial, admitindo-se que haveria uma tendência de concentração de populações nos centros urbanos existentes (Classe A) e em suas vizinhanças (Classe B), que deveria decrescer progressivamente (Classe C), até as proximidades dos mananciais mais importantes (reservatórios, rios principais e primários), buscando-se reduzir as possibilidades e os riscos de acesso direto dos poluentes a esses corpos d'água. (TARDELLI, 1987).

Dessa forma, foram estabelecidas na LPM condições para o saneamento, tais como: 
- Os sistemas públicos de abastecimento d'água e de esgotos sanitários limitam-se ao atendimento nas áreas Classe A e B;

- Os efluentes dos sistemas públicos de esgotos devem ser afastados da área de proteção e, caso inviável, receber tratamento e destinação adequada;

- Os sistemas particulares de esgotos devem possuir fossa séptica e sistema de infiltração dos efluentes no solo, garantida a proteção do lençol freático;

- A disposição de resíduos sólidos na área protegida não é permitida (SMA, 1992).

Além disso, a legislação define outras restrições e recomendações para a remoção da cobertura vegetal, a movimentação de terra e a limitação na concentração de nutrientes nos efluentes urbanos e rurais - caso verificadas manifestações de eutrofização no manancial - além daquelas relativas ao armazenamento e transporte de substâncias químicas.

A aplicação dessa legislação coube inicialmente à Secretaria dos Negócios Metropolitanos, através da Empresa de Planejamento da Grande São Paulo EMPLASA e, depois, à Secretaria do Meio Ambiente - SMA.

Segundo relatório da SECRETARIA DO ESTADO DO MEIO AMBIENTE et al (1999) alguns fatores que contribuíram para a lei não tivesse os efeitos desejados:

- Falta de participação das prefeituras e da sociedade. A lei de proteção foi elaborada sem a participação das prefeituras e da sociedade civil.

- Ausência de medidas indutoras que fomentassem formas de ocupação e atividades compatíveis com a proteção aos mananciais, acompanhada de medidas preventivas e punitivas na legislação.

- Conflitos de competência, falta de coordenação entre as ações governamentais e desaparelhamento das instituições 
- Investimentos estaduais em infra-estrutura de transportes na direção norte-sul que ajudassem a consolidar e expandir o pólo industrial, aumentando a oferta de empregos e concentrando a população na região sul do município.

- Construção de grandes conjuntos habitacionais pela Secretaria Estadual da Habitação.

- Atendimentos à população inserida nos assentamentos irregulares quanto ao fornecimento de luz e água, a medida em que estes loteamentos foram sendo urbanizados, regularizados ou anistiados pelo governo estadual e municipal.

- Transformação de áreas rurais em urbanas para aumentar a incidência de IPTU por parte dos municípios.

- Extensão da infra-estrutura e serviços às novas áreas urbanas, buscando valoriza-las para aumentar a alíquota dos impostos.

- A fiscalização centralizava o poder da polícia na esfera estadual, cuja estrutura deficiente e distante não condizia com a realidade cotidiana do processo de ocupação das áreas de mananciais dos municípios, gerando problemas de ordem prática.

- As ações punitivas ou corretivas mais drásticas tiveram que enfrentar a lentidão do poder judiciário.

A LPM foi promulgada numa época em que a Região Metropolitana de São Paulo se caracterizava como um dos principais pólos de crescimento econômico e urbano do país, atraindo milhões de novos moradores de todas as regiões especialmente população de baixa renda, que não podendo se estabelecer nas áreas centrais mais valorizadas, se instalaram nas regiões mais periféricas desprovidas de equipamentos e infra-estrutura, construindo por conta própria. 


\section{Consórcio Intermunicipal de Planejamento Integrado.}

A proteção das áreas de mananciais é um problema que atinge direta ou indiretamente vários municípios de São Paulo. Soluções para estes problemas não podem ser encontradas sem que todos os municípios interessados participem e colaborem.

Algumas tentativas de planejamento integrado estão sendo feitas na região, como o Consórcio Intermunicipal das Bacias do Alto Tamanduateí e Billings - Grande ABC. Oficialmente instalado em dezembro de 1999, o Consórcio Inter-municipal das Bacias do Alto Tamanduateí e Billings, mais conhecido como Consórcio do ABC, tem como objetivo representar o conjunto dos municípios de São Bernardo do Campo, Santo André, São Caetano do Sul, Diadema, Mauá, Ribeirão Pires e Rio Grande da Serra, em matérias de interesse comum perante as outras entidades de direito público e privado, nacionais e internacionais, além de elaborar políticas consensuais para o desenvolvimento desta região. Foi requisito primordial para a instalação do Consórcio que sua gestão seja absolutamente suprapartidária: quaisquer que sejam os partidos políticos dos prefeitos, que são os membros de seu órgão soberano, denominado Conselho de Municípios, deverá ser acatada a ordem de que o interesse regional de medidas adotadas deve prevalecer a questões partidárias. Este conceito permanece e é inquestionável.

Segundo a EMPLASA (2002d), os principais objetivos do consórcio são:

- "Planejar, adotar e executar, sempre que possível em cooperação técnica e financeira com os governos da União e do Estado, projetos, obras e outras ações destinadas a promover, melhorar e controlar, prioritariamente:

a) o abastecimento de água;

b) as condições de saneamento básico e ambiental e a qualidade das águas;

c) a coleta, tratamento e disposição dos resíduos sólidos;

d) a drenagem das águas pluviais, as atividades de prevenção das enchentes e o controle da erosão, bem como promover outras ações relativas à elevação da 
qualidade do meio ambiente na área das bacias hidrográficas do alto Tamanduateí e Reservatório Billings".

- "Promover formas articuladas de planejamento do desenvolvimento regional, criando mecanismos conjuntos para consultas, estudos, execução, fiscalização e controle de atividades que interfiram na área compreendida no território dos municípios consorciados, entre outras, respeitadas as prioridades do item anterior, nas questões referentes a:

a) interligação do sistema viário e de transportes;

b) desenvolvimento urbano e controle de uso do solo;

c) caracterização socioeconômica e dinâmica demográfica;

d) desenvolvimento econômico e social e da qualidade de vida da população;

e) planejamento e desenvolvimento de serviços, obras e outras medidas nas áreas limítrofes entre municípios consorciados". 


\section{MATERIAIS E MÉTODOS}

\subsection{Materiais}

Os materiais utilizados no trabalho foram:

Fotografias aéreas:

Foram utilizadas fotografias do levantamento aerofotogramétrico disponibilizadas pela Prefeitura do Município de São Bernardo do Campo:

Ano: 1998, escalas 1:30.000 e 1:5.000 (único disponível em formato digital)

Dados estatísticos:

Compêndio estatístico do Município de São Bernardo do Campo. Este relatório é emitido pela Prefeitura do Município de São Bernardo do Campo e contém análises do crescimento populacional, da urbanização, etc.

Dados vetoriais:

A PMSBC possui dados vetoriais georreferenciados da cidade em forma digital. Estes dados contêm os limites da cidade, as principais vias e logradouros e os limites da represa.

Entre os dados vetoriais há o limite da represa. Este dado apresentou diversas versões, pois o limite legal (oficial) da represa não foi mapeado pela prefeitura. Durante o desenvolvimento da metodologia trabalhou-se com um limite que não era o oficial e esses limites variam de acordo com a época do ano. Essa informação teve muita importância, pois áreas próximas à represa e que estão sendo invadidas, são áreas críticas, tanto para a qualidade da água quanto para a segurança da população.

Imagens de satélite:

Foi utilizada uma imagem do satélite LANDSAT 7 ETM+, data: 03/09/99, órbitasponto: 219-076/219-077, bandas: 1,2,3,4,5,6h,61,7.

Software:

O software utilizado para o processamento digital de imagens foi o IDRISI 32, software de sistemas de informações geográfico desenvolvido pela Clark Labs, da 
Clark University (EUA). Este software foi escolhido por ser didático, por possuir uma interface gráfica de fácil entendimento e pelo custo relativamente baixo.

Hardware:

Para o desenvolvimento do trabalho foi utilizada a infra-estrutura do Laboratório de Geoprocessamento da USP que disponibilizou computadores, impressoras, mesas digitalizadoras, etc.

\subsection{Desenvolvimento da metodologia}

As imagens utilizadas no desenvolvimento do projeto foram as do satélite LANDSAT 7. A escolha pelo uso destas imagens foi devido à resolução espacial de $30 \mathrm{~m}$ no modo multiespectral, que para os estudos realizados, foi o mais adequado. Além disso, à facilidade de obtenção das imagens, pois já existiam outras imagens da região de anos anteriores disponíveis no Laboratório de Geoprocessamento.

Para o planejamento urbano do município, uma visão geral da ocupação e distribuição das atividades na cidade torna-se necessária. Para isso, as imagens LANDSAT cumprem muito bem os objetivos, fornecendo uma escala de análise compatível com o estudo desejado, que é o mapeamento do município.

No processo de elaboração do sistema de classificação do uso do solo foram utilizadas técnicas de processamento digital de imagens, com estudos relativos aos critérios de classificação, aplicações de técnicas em uma área teste e adequação e aplicação do sistema ao município de São Bernardo do Campo. Estes procedimentos serão descritos a seguir. 
A metodologia sugerida no desenvolvimento segue o fluxograma apresentado no Quadro 1.

Quadro 1 - Fluxograma das atividades desenvolvidas

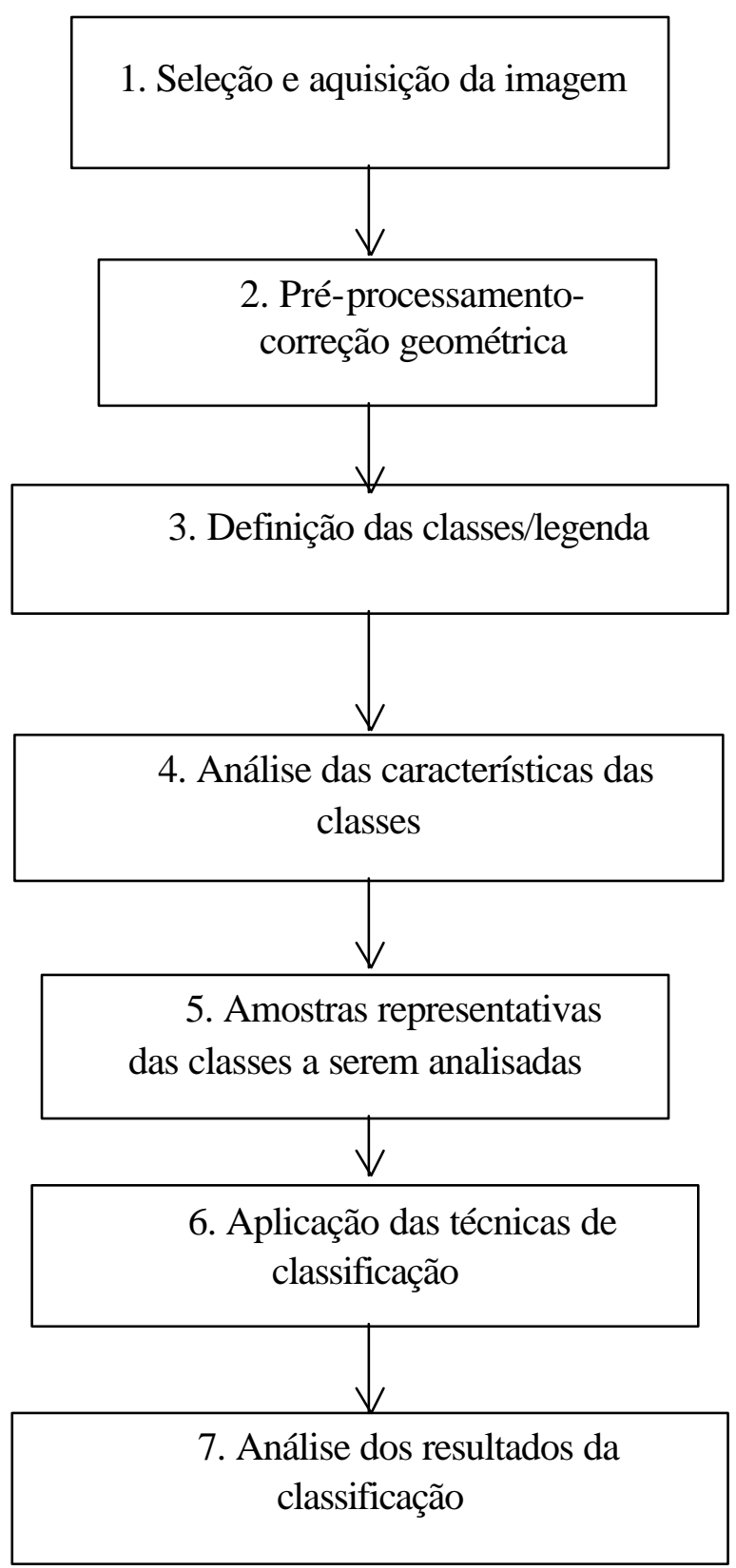




\subsubsection{Pré-processamento/ correção geométrica}

Segundo IBGE (2001), a correção geométrica produz o georreferenciamento da imagem, ou seja, estabelece uma relação geométrica entre os pixels da imagem e as coordenadas cartográficas da área correspondente. Através da correção geométrica a imagem adquire propriedades de um mapa, com todos os pixels referenciados a um sistema de Projeção Cartográfica. O Registro é o ajuste de uma imagem ao sistema de coordenadas.

Na correção geométrica realizada através de coordenadas geográficas, o analista toma pontos de controle na área de estudo e associa, a cada ponto, um par de coordenadas geográficas. O sistema ajusta todos os pixels dentro destes pontos de controle, em função de suas coordenadas.

Obtida a imagem corrigida, o passo seguinte é fazer o registro da imagem com um sistema de referência, através de cartas topográficas ou coordenadas obtidas pelo GPS (Global Positioning System). Quando se utilizam cartas topográficas, o procedimento consiste em tomar coordenadas de pontos devidamente identificáveis, tanto na imagem quanto na carta topográfica, para que o sistema possa rotular geograficamente o restante dos pontos da área, ou seja, os pixels da área de interesse nas imagens de satélite. O nível de correção da imagem depende do número de pontos de controle.

O registro da imagem é feito utilizando sistemas de equações polinomiais de primeiro, segundo e de terceiro grau. $\mathrm{O}$ registro quando feito imagem-imagem utiliza a denominação retificação geométrica, cujo procedimento é semelhante ao que se faz para imagem-carta.

Este procedimento permite que haja sobreposição entre imagens e outros dados vetoriais georreferenciados.

Na correção geográfica das imagens LANDSAT 7 de 1999 (bandas 1,2,3,4,5,6h,61,7) foram utilizados 16 pontos de controle distribuídos por toda a imagem. Os pontos foram obtidos utilizando-se como referência, os arquivos vetoriais georreferenciados do município em formato digital. Foram utilizados os pontos mais facilmente identificáveis como as intersecções das ruas e rios, pistas de aeroportos, os prédios 
proeminentes, montanhas e outras feições óbvias visíveis na imagem e nos arquivos vetoriais. Procurou-se distribuir os pontos de controle de forma a cobrir toda a região do município.

O software utilizado apresenta diversas opções para a realização do registro. As funções podem ser: linear, quadrática ou cúbica e os interpoladores podem ser: o vizinho mais próximo ou bilinear. Para o registro das imagens utilizou-se a função linear e interpolador bilinear. Segundo Eastman (1998), o interpolador bilinear é o mais adequado para imagens de sensoriamento remoto. O sistema de referência utilizado foi o Universal Transverse Mercator (UTM) Zona 23, Datum WGS 84.

O software IDRISI apresenta ao fim do processo, o Erro Quadrático Médio (RMS Root Mean Square) de todos os pontos e os erros residuais de cada ponto. O RMS descreve o erro posicional típico de todos os pontos em relação à equação. De acordo com o U. S. National Map Accuracy Standards, o RMS por imagem deve ser menor que a metade da resolução na imagem de saída.

O RMS obtido no registro das imagens foi de 0,9021692. Isso significa um valor dentro do esperado.

Três dos dezesseis pontos de controle que apresentaram erros residuais altos (maiores que 1,5 ) os quais foram omitidos, diminuindo o erro final.

\subsubsection{Definição das classes de uso do solo/ legenda.}

Com base nos interesses da Prefeitura, procurou-se definir as classes de uso do solo e cobertura natural da terra que melhor atendessem às suas necessidades.

Na definição destas classes levou-se em consideração as relações:

- Classes de uso do solo definidas pela lei de uso do solo no município (legislação do uso do solo),

- Classes possíveis de serem observadas e obtidas através das imagens orbitais e

- Real distribuição das classes de uso do solo no município de modo a gerar uma classificação compatível às três perspectivas. 
Este passo foi o resultado da interação entre as necessidades políticas e as técnicas utilizadas, considerando observações de campo e as dimensões das áreas.

As classes de uso do solo necessárias às atividades de planejamento da Prefeitura de São Bernardo do Campo baseiam-se nas atividades sociais desenvolvidas na área, nas características econômicas da ocupação, na descrição física da área, incluindo: o tamanho dos lotes urbanos, a densidades de construção e o padrão construtivo, por exemplo. (ANDERSON et al., 1976) .

As descrições dos perfis das imagens nestas áreas também estão incluídas. Estas descrições consideram as características sociais, as formas e as características espectrais das imagens. As características espectrais e espaciais de cada classes de uso do solo foram avaliadas para cada banda da imagem orbital.

As classes de uso do solo definidas incluem três grupos principais: vegetação, água e áreas urbanas, de acordo com o entendimento geral da prefeitura.

O grupo Áreas Urbanas fi posteriormente subdividido, pois houve a necessidade de maiores informações.

As duas principais vias que atravessam o município, a Via Anchieta e a Rodovia dos Imigrantes, foram utilizadas como referência para a classificação do uso do solo. Assim, o sistema de transporte foi definido como outra classe a ser atingida.

Assim, as classes consideradas importantes foram então definidas:

a) Água

Esta classe foi representada pelos limites da Represa Billings e a Represa do Rio das Pedras (Figura 16). 


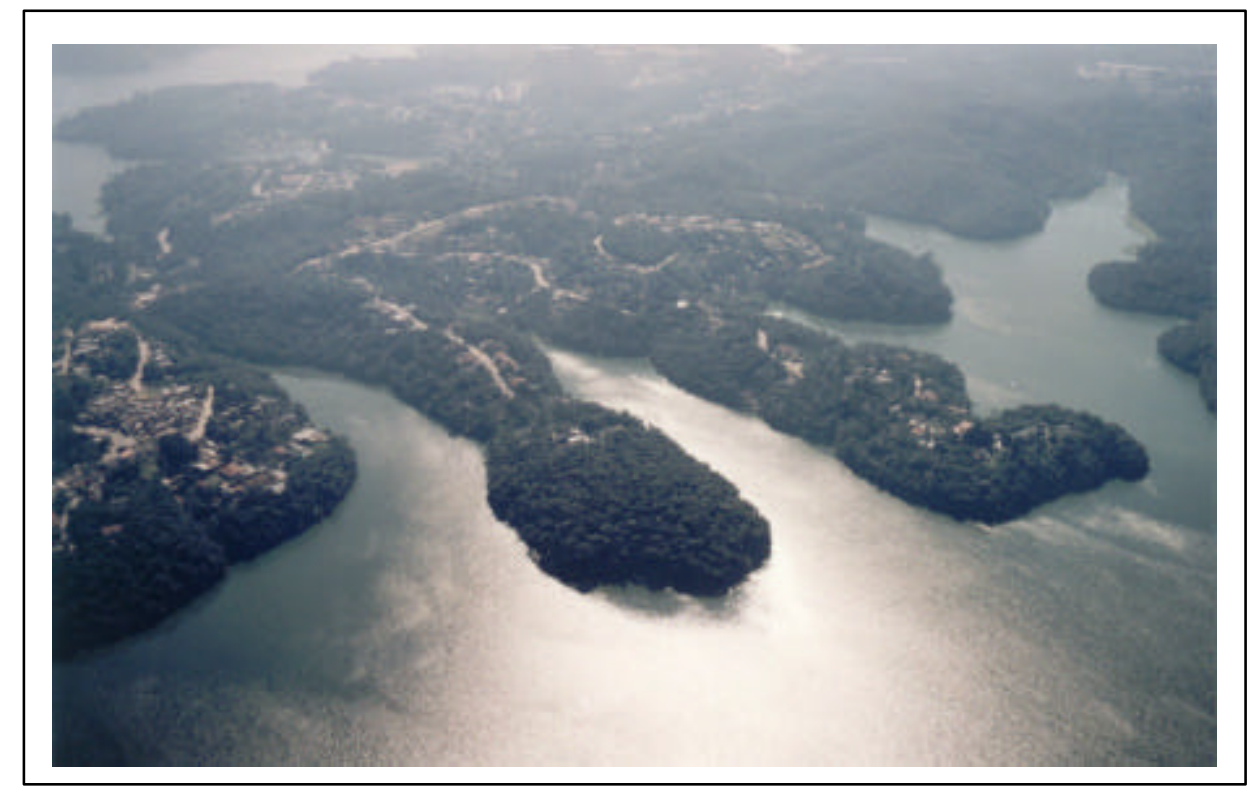

Figura 16 - Represa Billings

b) Vegetação

Esta classe é composta principalmente pelas áreas da Reserva Florestal da Mata Atlântica e o Parque Estadual da Serra do Mar. A área protegida é coberta por diferentes tipos de vegetação que variam das densas florestas à vegetação rasteira. A princípio, a distinção destes tipos diferentes não foi considerada essencial e a vegetação foi então generalizada em uma classe apenas (Figura 17).

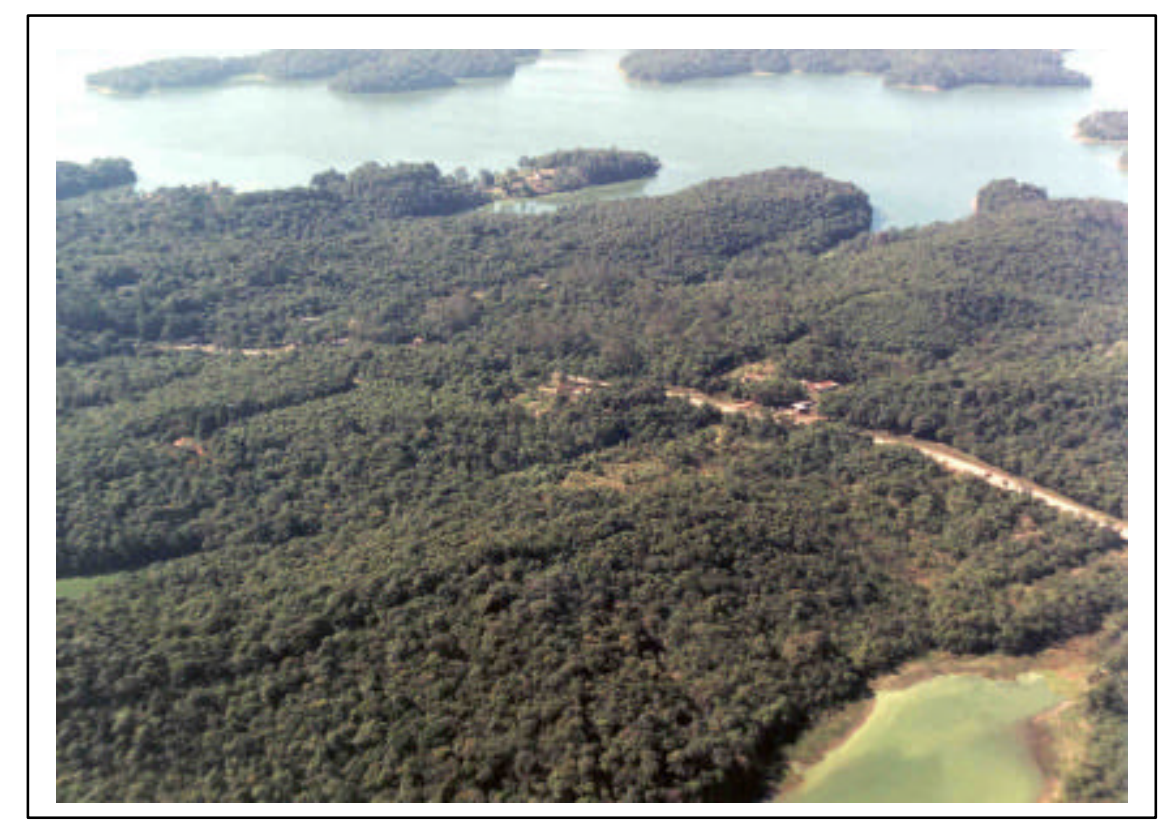

Figura 17 - Áreas de florestas 


\section{c) Áreas Urbanas}

A distinção das classes dentro das áreas urbanas e a expansão dentro das áreas protegidas foram consideradas prioridade na definição das classes de uso do solo urbano. Os resultados das classes foram:

Áreas de Alta Densidade (Urbano Alta Densidade) - lotes com dimensões de aproximadamente 50 a $75 \mathrm{~m}^{2}$, construções que cobrem quase totalmente o lote, população de baixa renda e geralmente localizadas em regiões da cidade que apresentam alta concentração de construções (Figura 18).

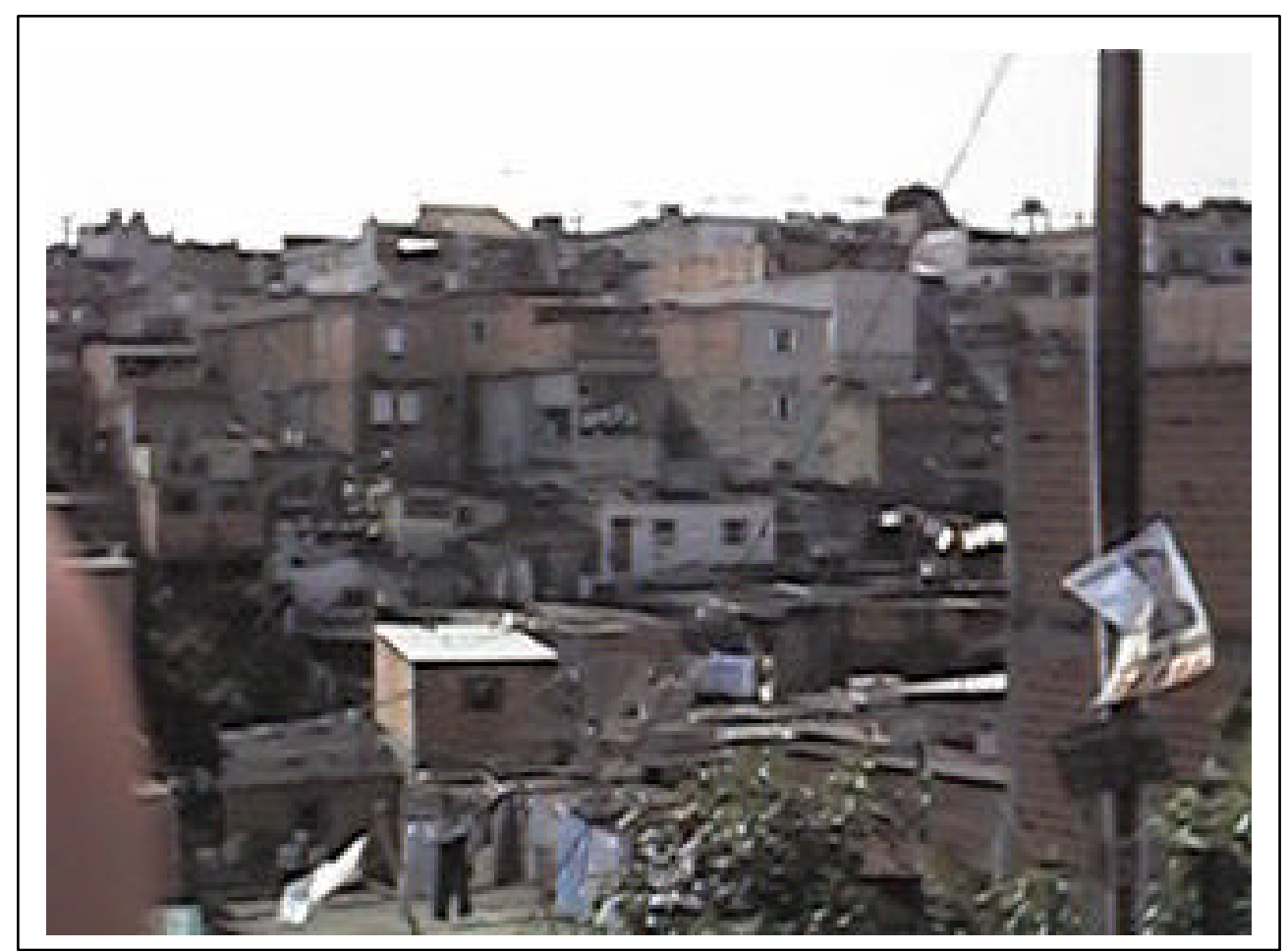

Figura 18 - Áreas urbanas de alta densidade

Áreas de Média Densidade (Urbano Média Densidade) - lotes de aproximadamente 125 a $250 \mathrm{~m}^{2}$, população de renda média com predominância de classe trabalhadora, presença de pequenas empresas e comércio (Figura 19). 


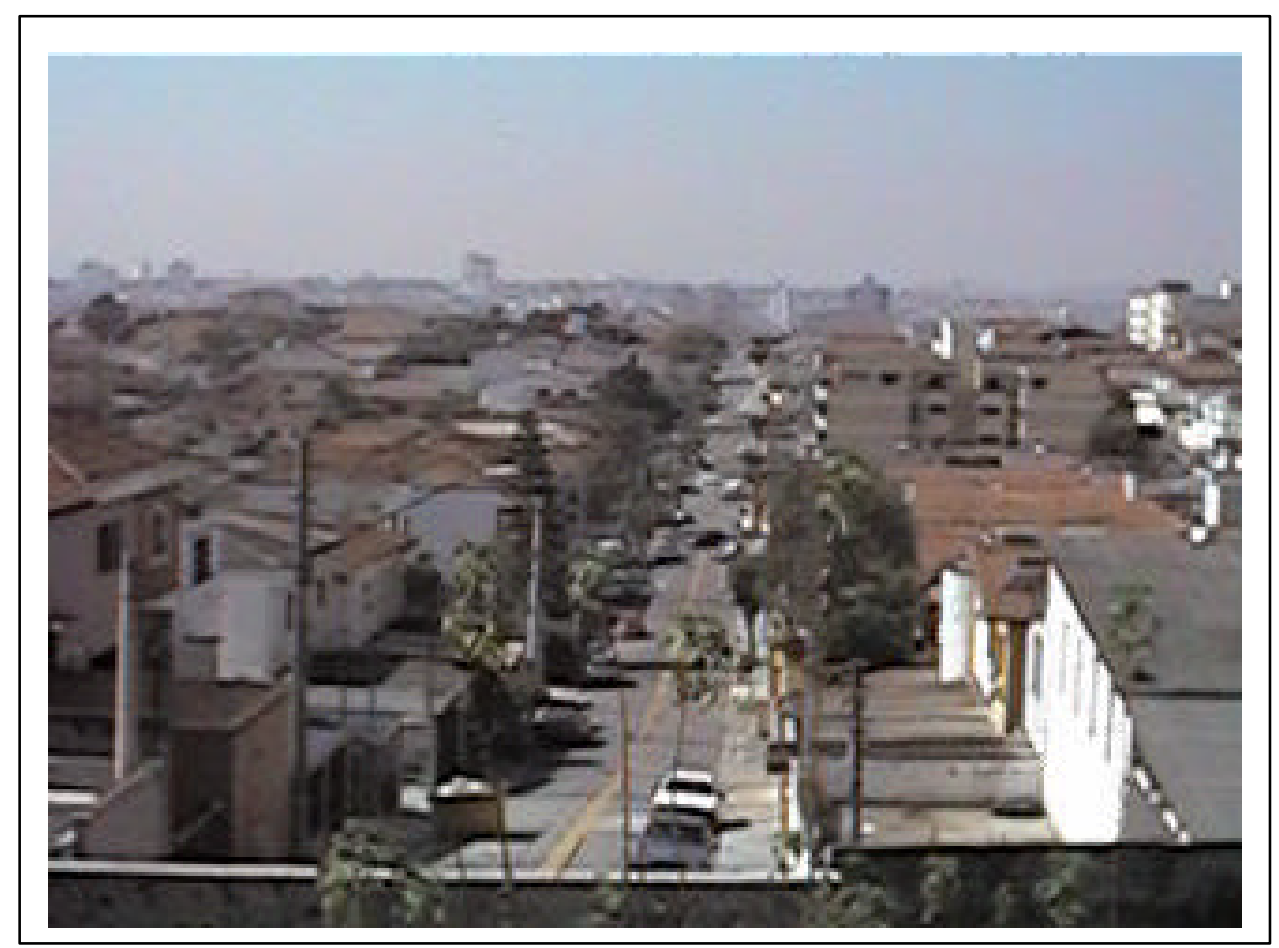

Figura 19 - Áreas urbanas de média densidade

Áreas de Baixa Densidade (Urbano Baixa Densidade) - lotes de grande extensão, acima de $250 \mathrm{~m}^{2}$, geralmente população de média a alta renda, acesso às áreas de lazer e áreas verdes. Ocupação consolidada (Figura 20).

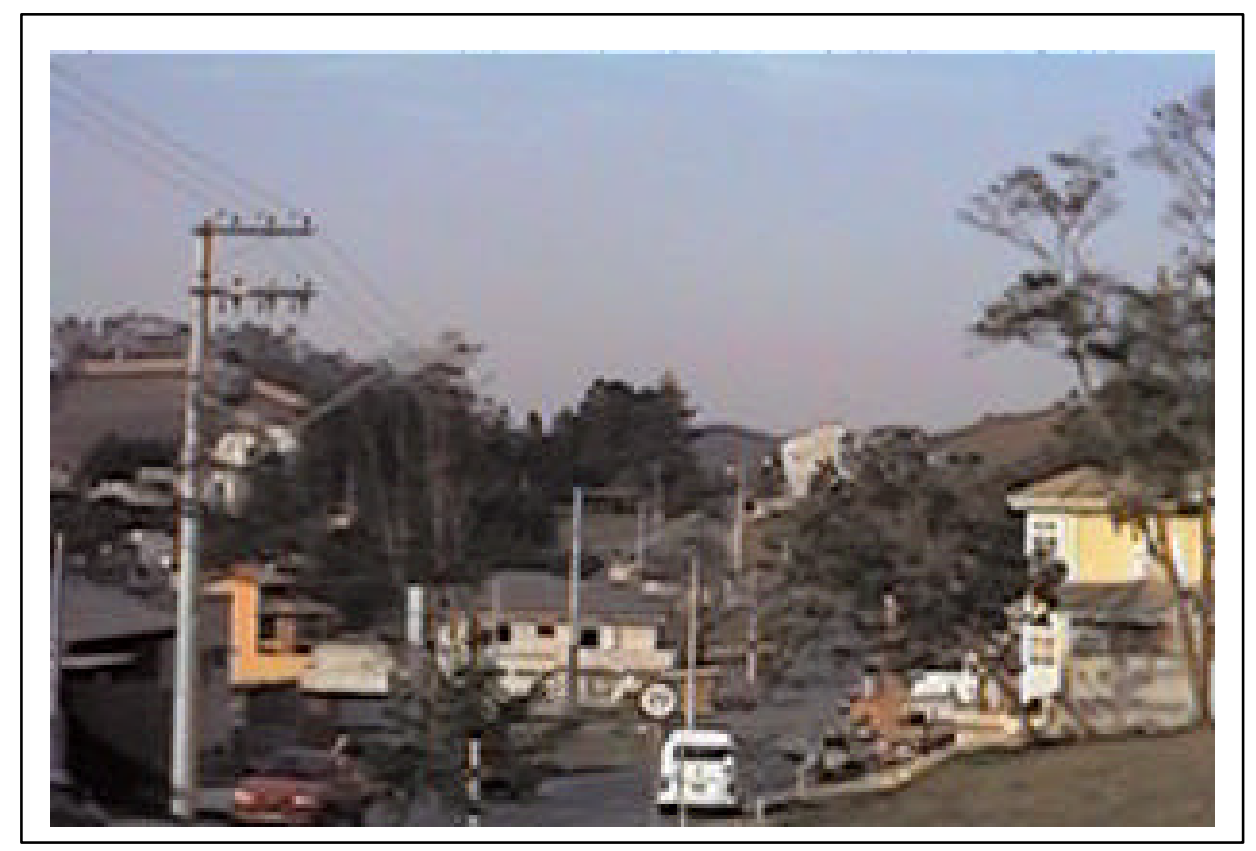

Figura 20 - Áreas urbanas de baixa densidade 
Áreas de Urbanização Irregular (Urbano Irregular) - áreas em locais de preservação ambiental, geralmente alta densidade de construção, ausência de áreas de lazer ou áreas verdes, presença de solo exposto. A ocupação das áreas protegidas (Áreas de Urbanização Irregulares) segue um padrão conhecido, onde a característica espectral principal é a presença de solo exposto e construções. A descrição do processo de ocupação nestas áreas faz possível sua identificação como feição especial nas imagens (Figura 21).

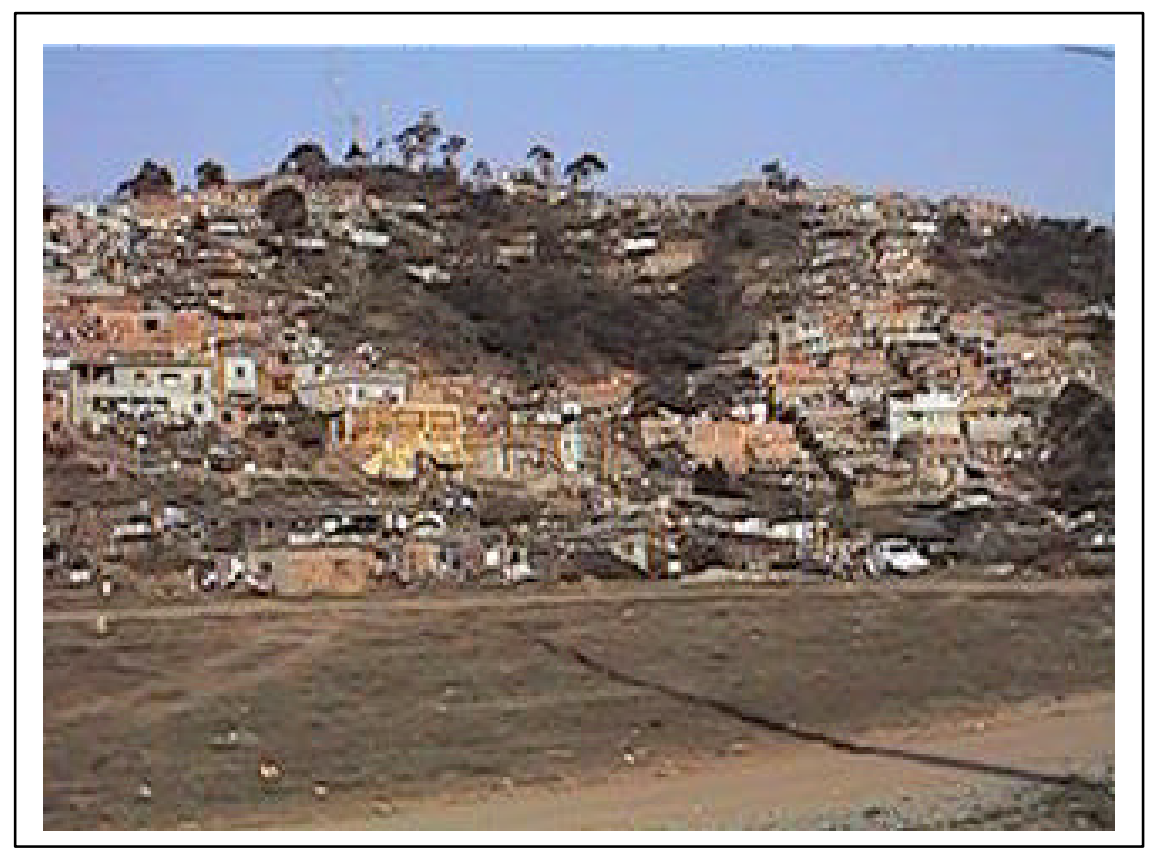

Figura 21 - Áreas urbanas irregulares

Áreas Multi-familiares (Urbano Vertical) - a localização e distribuição das áreas multi-familiares (verticalização) é importante para a Prefeitura, pois são áreas que apresentam características diferentes das unidades unifamiliares. São áreas que diferem quanto à concentração populacional requisitando serviços e infra-estruturas particulares. A concentração de edificações forma ilhas de calor, pois a dissipação da energia é dificultada e, nas imagens, observa-se a presença de sombras (Figura 22). 


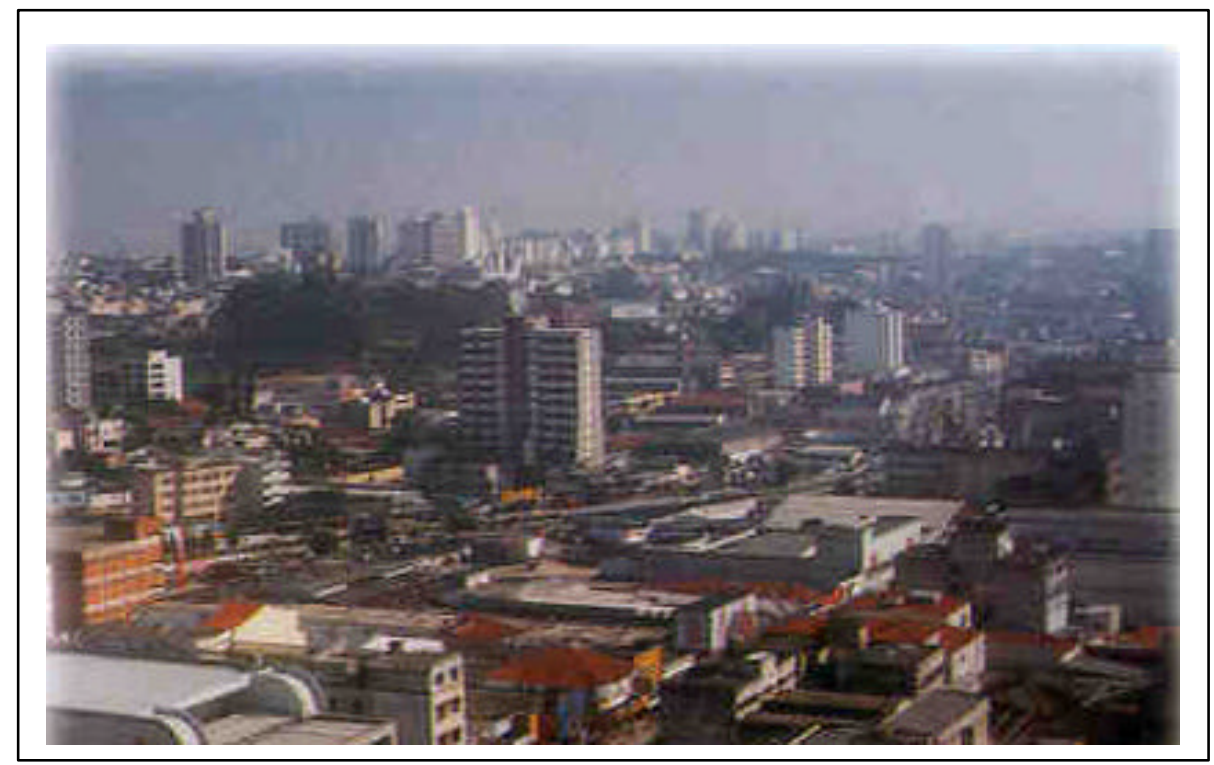

Figura 22 - Áreas multifamiliares

d) Indústrias e Comércio (Complexos Industriais e Comerciais) - caracterizadas principalmente pelas grandes corporações internacionais que ocupam áreas extensas como a VW, Ford, Mercedes Benz, Nestlé, Carrefour, Rhodia, etc. As pequenas indústrias seguem os mesmos padrões construtivos das grandes empresas (Figura 23).

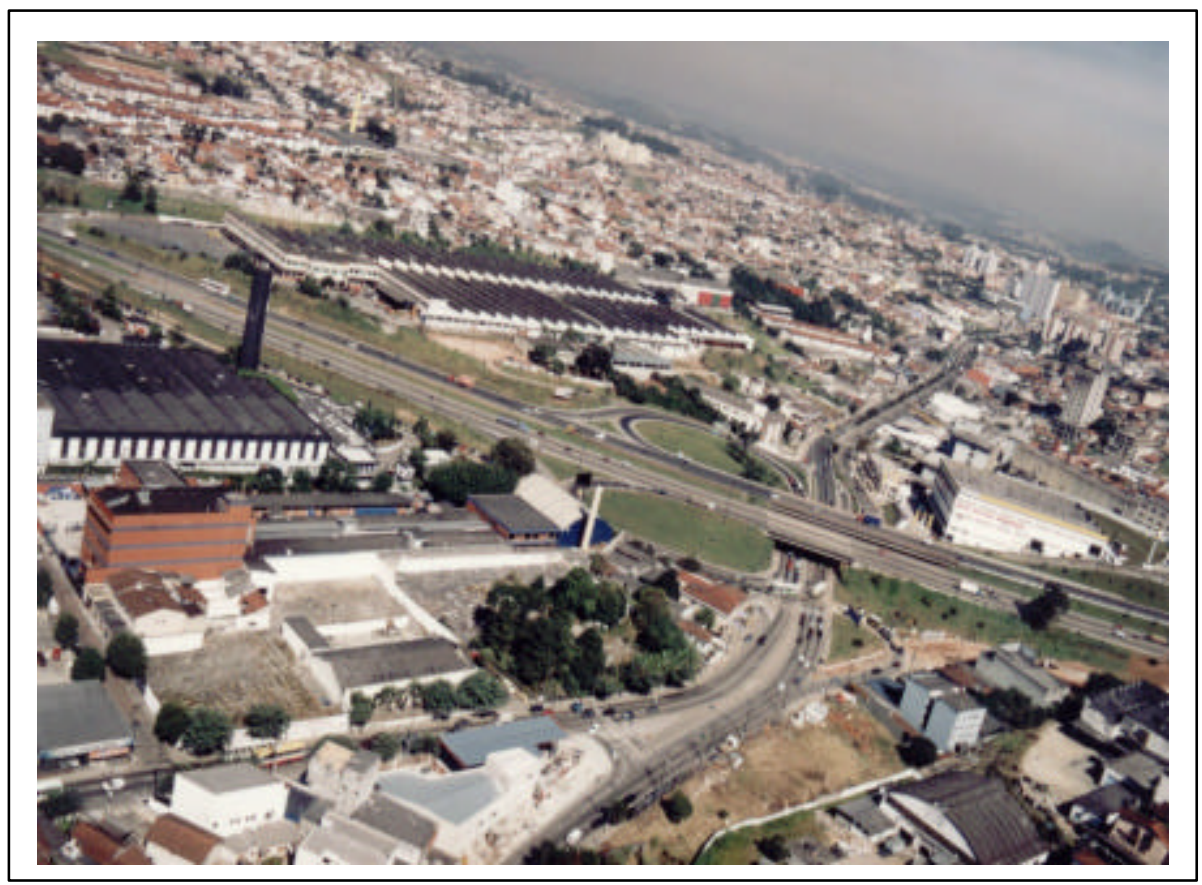

Figura 23 - Indústria e comércio 
O desenvolvimento econômico da região foi devido principalmente às corporações internacionais de grande porte, como Ford e Volkswagen. Estas empresas podem, geralmente, ser detectadas nas imagens orbitais pela sua forma e extensão significativa. A identificação é facilitada também pela presença dos pátios para os automóveis. Estas áreas são muito extensas em relação às áreas urbanas.

e) Sistemas Viários

A Via Anchieta e a Rodovia dos Imigrantes são as duas principais vias que cortam o município. Esta classe foi considerada útil, porém não essencial (Figura 24).

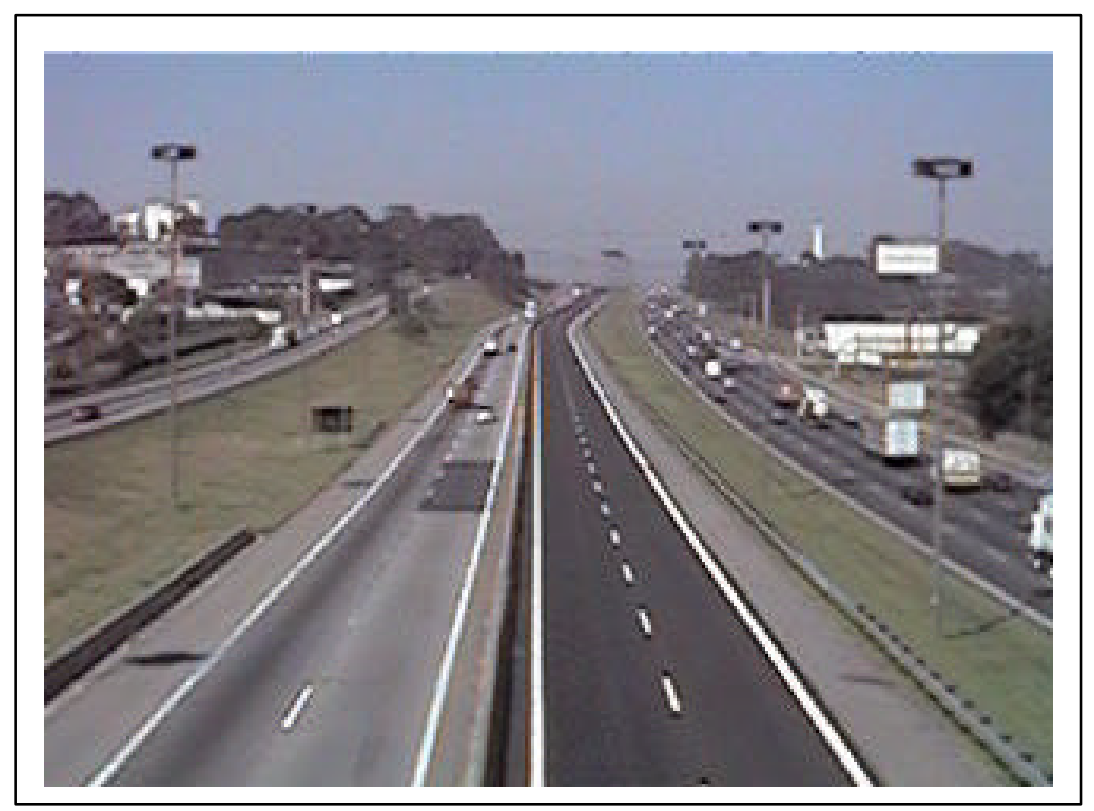

Figura 24 - Sistemas viários

\subsubsection{Análise das características espectrais das classes.}

Definidas as classes de interesse, passou-se à observação das características espectrais destas classes e à aplicação de diversas técnicas de classificação para a extração destas classes considerando três categorias: as classes bem definidas espectralmente, as classes possíveis de serem extraídas através de técnicas de processamento digital de imagens e as classes extraídas por interpretação visual de imagens e evolução multitemporal.

\section{1) Características espectrais}


a) algumas classes, como a água e as áreas vegetadas possuem comportamento espectral conhecido. Estas classes são facilmente definidas por suas características espectrais, utilizando técnicas de classificação pixel a pixel. (JACKSON, CARTES, SMITH e GARDNER, 1980 e IOKA e KODA, 1986).

b) Algumas classes de uso do solo são constituídas de elementos diferentes agregados dentro de um padrão de textura na imagem que pode ser extraída utilizando técnicas de processamento digital de imagens. Estas classes são obtidas pela extração de suas características texturais específicas através de técnicas de filtragens (BARALDI e PARMIGGIANI, 1991 e COULOMBE, et al., 1991).

\section{2) Interpretação visual}

a) Algumas classes são mais complexas e devem ser obtidas pela interpretação visual. Estas são as últimas classes a serem obtidas.

O conceito é baseado na definição de prioridades na classificação do uso do solo. Ele considera uma classificação pixel a pixel para a extração da água e áreas verdes, divididas em gramados, arbustos e florestas. Depois, uma classificação baseada em características texturais é aplicada somente em áreas urbanas para uma melhor definição de classes de uso urbano.

\subsubsection{Amostras a serem analisadas.}

A escolha das amostras é uma etapa importante do processo que pode comprometer a classificação.

As amostras dessas classes foram retiradas pela interpretação visual das imagens, auxiliado pelo conhecimento dos técnicos da região e através das fotografias aéreas do ano de 1998, escala 1:5000, disponíveis em formato digital. Desta forma foi possível a retirada das amostras mais específicas como telhados, pátios de estacionamento, etc com maior precisão. O conhecimento prévio da área auxiliou na retirada das amostras (Figura 25). 
As classes como a água e a vegetação foram facilmente visualizadas. A região apresenta estas duas classes bem definidas: as áreas protegidas apresentam extensas áreas verdes correspondentes às florestas e a região da represa.

Classes mais complexas como as classes urbanas, apresentam dificuldades devido à grande variabilidade espectral. A variabilidade espectral é devida à variedade de materiais (diferentes tipos de telhas das casas, pavimentos, solo exposto, vegetação), à densidade (dimensão dos lotes) e à verticalização (sombra causada pela altura dos edifícios).

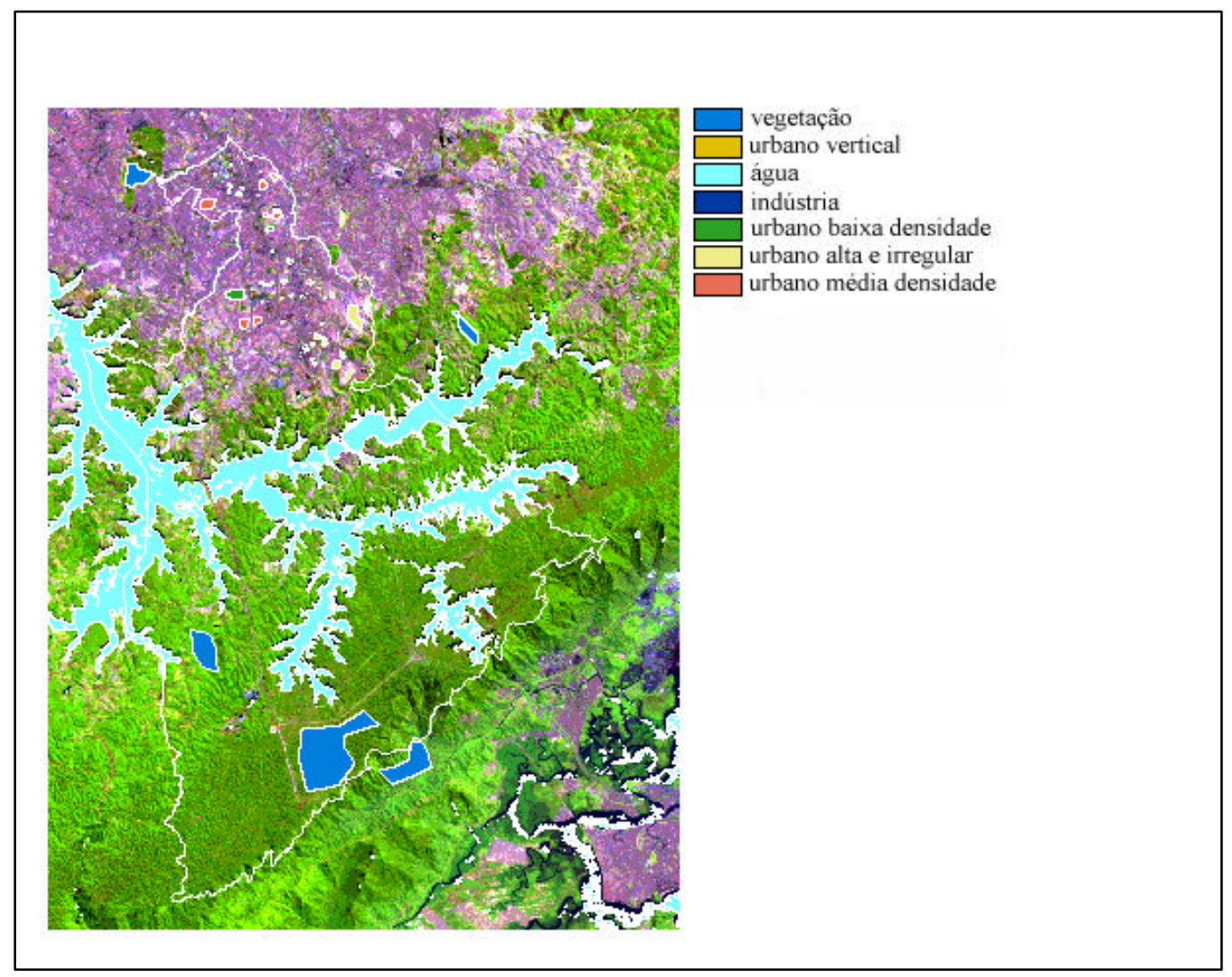

Figura 25 - Localização das amostras das classes analisadas na composição colorida 3B4G5R.

Segundo ZHANG (1999), alguns trabalhos com classificação de imagens de satélite, utilizam métodos de análise de textura que são utilizados para introduzir informações espaciais de diferentes classes de objetos dentro da classificação. As imagens geradas pela análise de textura são classificadas diretamente ou são utilizadas como uma banda adicional junto com outras bandas multiespectrais na classificação. 
Assim, para melhorar a classificação e de forma a diminuir a variabilidade espectral das áreas urbanas, utilizou-se o filtro passa baixa em uma das bandas. $\mathrm{O}$ filtro passa baixa atenua os componentes de alta frequiência, provocando o "borramento" da imagem. Para a escolha da melhor banda a ser filtrada, inicialmente foram analisadas as bandas que apresentavam maiores desvios padrões e depois, a banda que visualmente apresentava maior variação de contraste dentro das áreas urbanas. (Tabela 18).

A Tabela 18 mostra os valores mínimos, máximos, médias e desvios padrões das 8 (oito) bandas analisadas neste estudo.

Como pode ser observado nesta tabela, a amplitude de variação dos níveis de cinza das bandas 5 e 7 são maiores do que as demais bandas.

Tabela 18 - Análise dos níveis de cinza das bandas da imagem LANDSAT 7.

\begin{tabular}{|c|c|c|c|c|c|}
\hline Banda & $\begin{array}{c}\text { Valor } \\
\text { mínimo }\end{array}$ & $\begin{array}{c}\text { Valor } \\
\text { máximo }\end{array}$ & Média & $\begin{array}{c}\text { Desvio } \\
\text { Padrão }\end{array}$ & $\begin{array}{c}\text { Coef. } \\
\text { Variação }\end{array}$ \\
\hline 1 & 29 & 254 & 83,41 & 7,26 & 0,088 \\
\hline 2 & 31 & 235 & 60,44 & 8,60 & 0,142 \\
\hline 3 & 25 & 227 & 54,76 & 14,36 & 0,262 \\
\hline 4 & 23 & 231 & 70,38 & 17,34 & 0,247 \\
\hline 5 & 3 & 248 & 55,87 & 22,37 & 0,400 \\
\hline $6 h$ & 96 & 205 & 150,72 & 8,76 & 0,058 \\
\hline 61 & 115 & 170 & 143,72 & 4,51 & 0,031 \\
\hline 7 & 5 & 255 & 37,87 & 21,98 & 0,579 \\
\hline
\end{tabular}

Apesar da banda 5 apresentar desvio padrão maior do que a banda 7 (22.3687 e 21,9767 respectivamente), visualmente a banda 7 apresenta maiores contrastes entre as classes urbanas e a vegetação do que a banda 5 (Figura 26).

Através desses critérios, foi escolhida a banda 7. Esta banda foi filtrada com filtros de média de tamanhos diferentes de janela: 3x3 e 7x7. Nesta região existem feições 
cujas dimensões justificam as dimensões destas máscaras. Feições como as indústrias, pátios, estacionamentos, campo de futebol, etc.

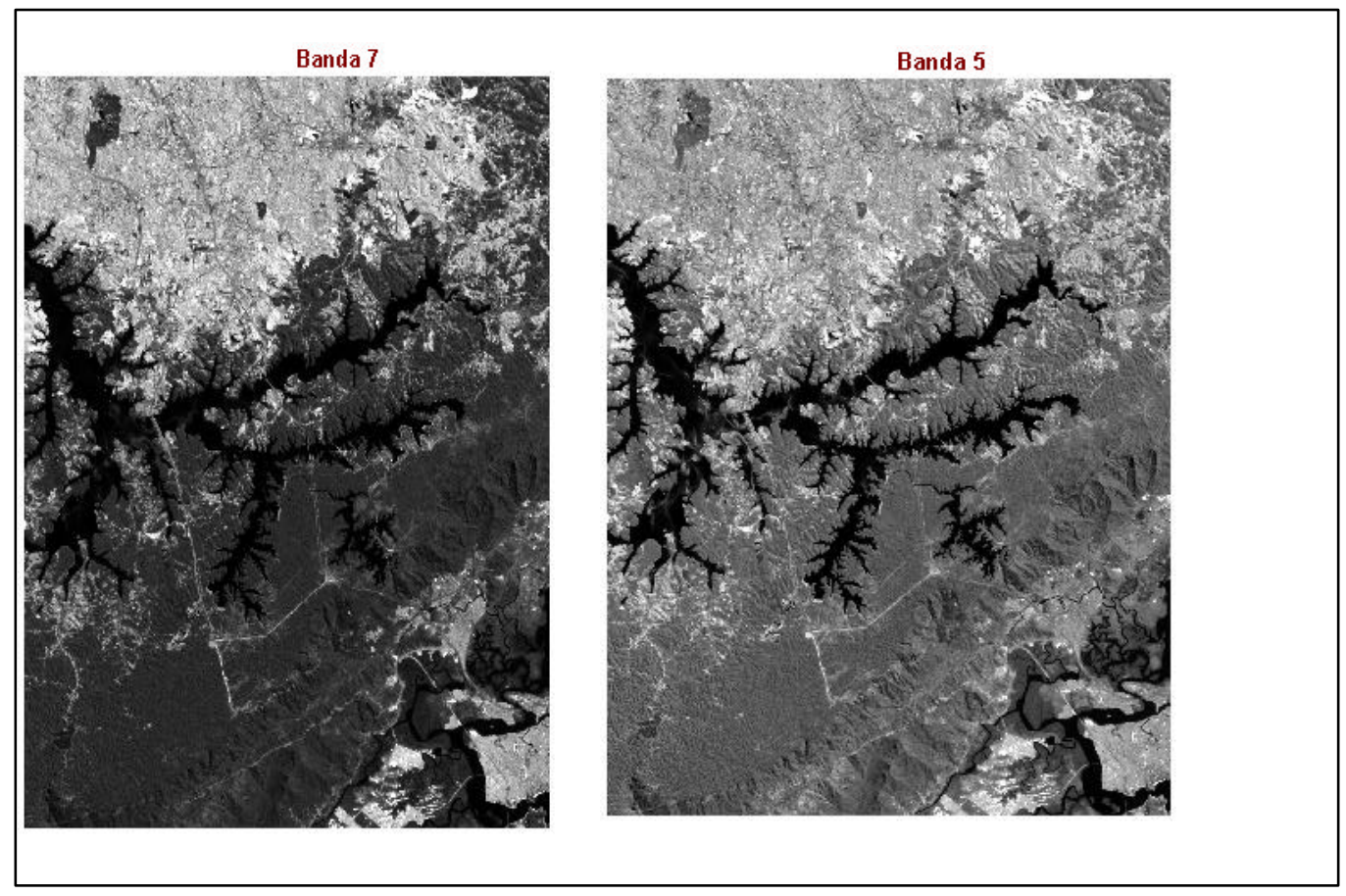

Figura 26 - Bandas 7 e 5 com realce linear com saturação, respectivamente.

As imagens geradas pela filtragem foram utilizadas diretamente na classificação como bandas adicionais junto às outras bandas multiespectrais, introduzindo informações espaciais às análises.

Foram geradas as assinaturas espectrais das amostras com o processamento de 7 bandas. As bandas utilizadas nesta etapa foram: bandas 2, 3, 4, 5, 7, banda 7 filtrada com máscara 3x3 e a banda 7 filtrada com máscara $7 \times 7$.

Os histogramas e as estatísticas das amostras (média, variância, desvio padrão) também foram analisados. As assinaturas possuem informações estatísticas acerca dos valores dos níveis digitais dos pixels contidos nas áreas de treinamento de cada classe (Figura 27 e 28).

Cada pixel da área de estudo possui um valor diferente em cada uma das bandas da imagem. Estes valores formam uma assinatura espectral única que podem ser comparadas às outras assinaturas criadas.

Os pixels da imagem são associados à assinatura a que mais assemelham. 


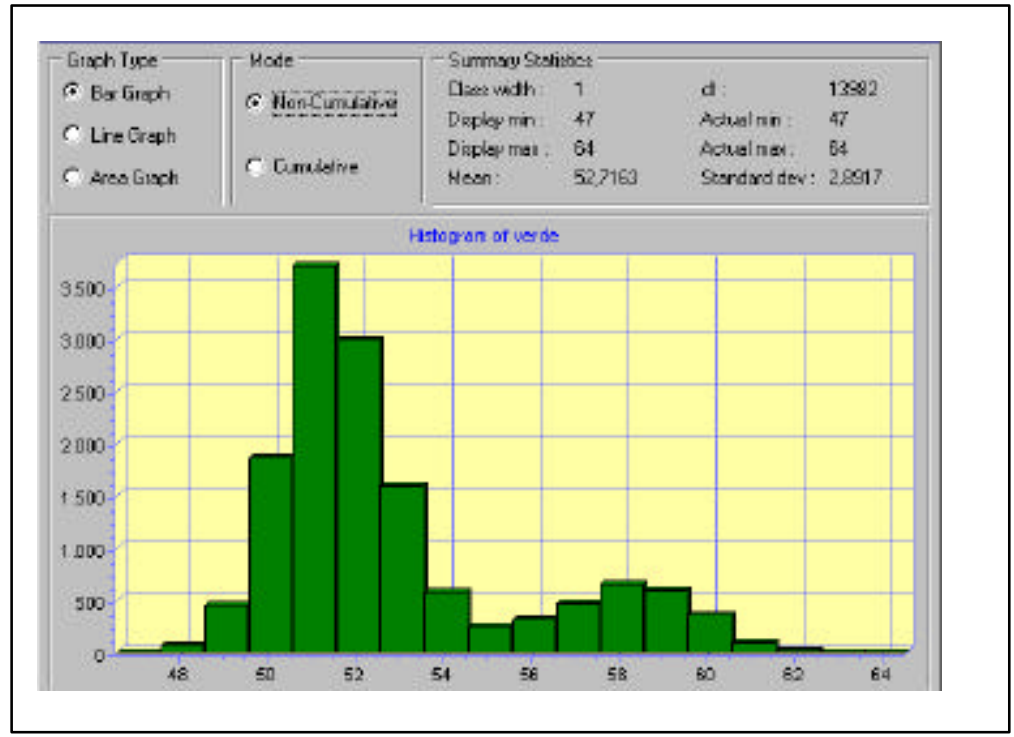

Figura 27 - Histograma das amostras da classe vegetação.

Pelo histograma da água (Figura 28), pode-se perceber a presença de dois picos. Esses dois picos são devidos à água e à mancha clara na represa. Não foi possível a identificação do material que compõe a mancha, e não houve interesse na sua identificação por não se tratar do escopo do trabalho. $O$ interesse foi apenas a delimitação da represa e sua identificação na classificação. Optou-se pela classificação da represa como um todo e não na separação e identificação dos dois materiais.

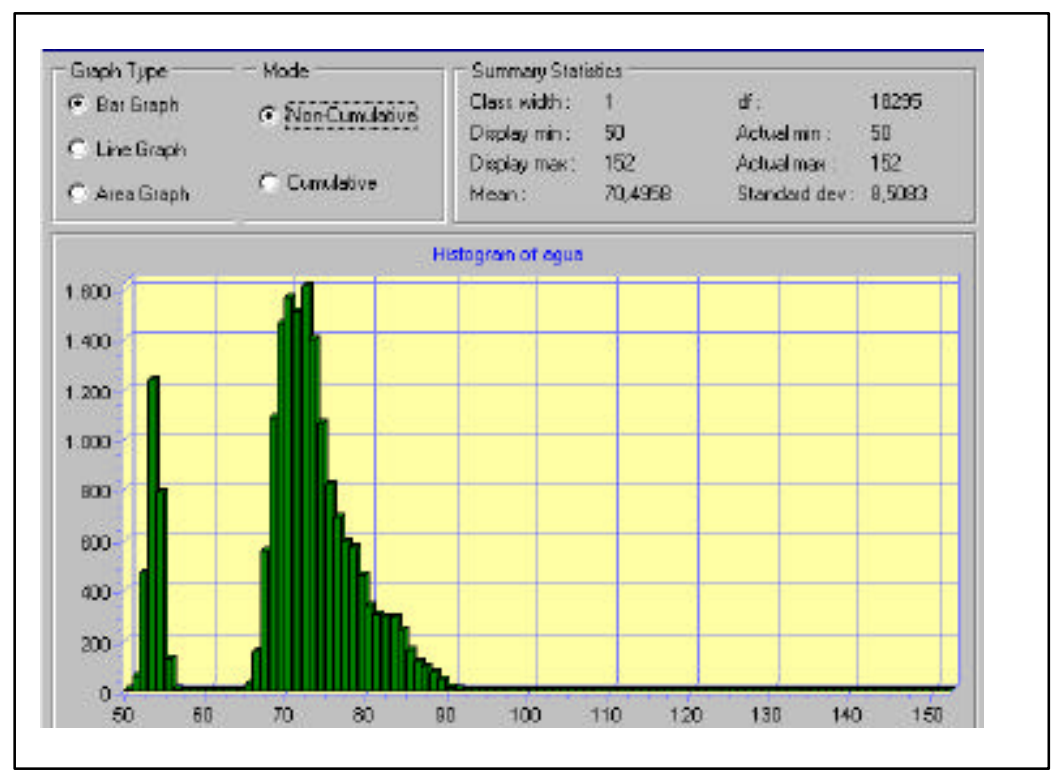

Figura 28 - Histograma da amostra de água 
A Figura 29 permite verificar a grande variabilidade espectral das classes a serem analisadas. Podem-se notar as diferenças nas assinaturas das classes vegetação e indústria em relação às classes urbanas. As classes urbanas apresentam pequenas diferenças entre elas, o que confirma a dificuldade na separação destas classes.

As classes vegetação e indústria mostram diferenças que permitem uma melhor separação.

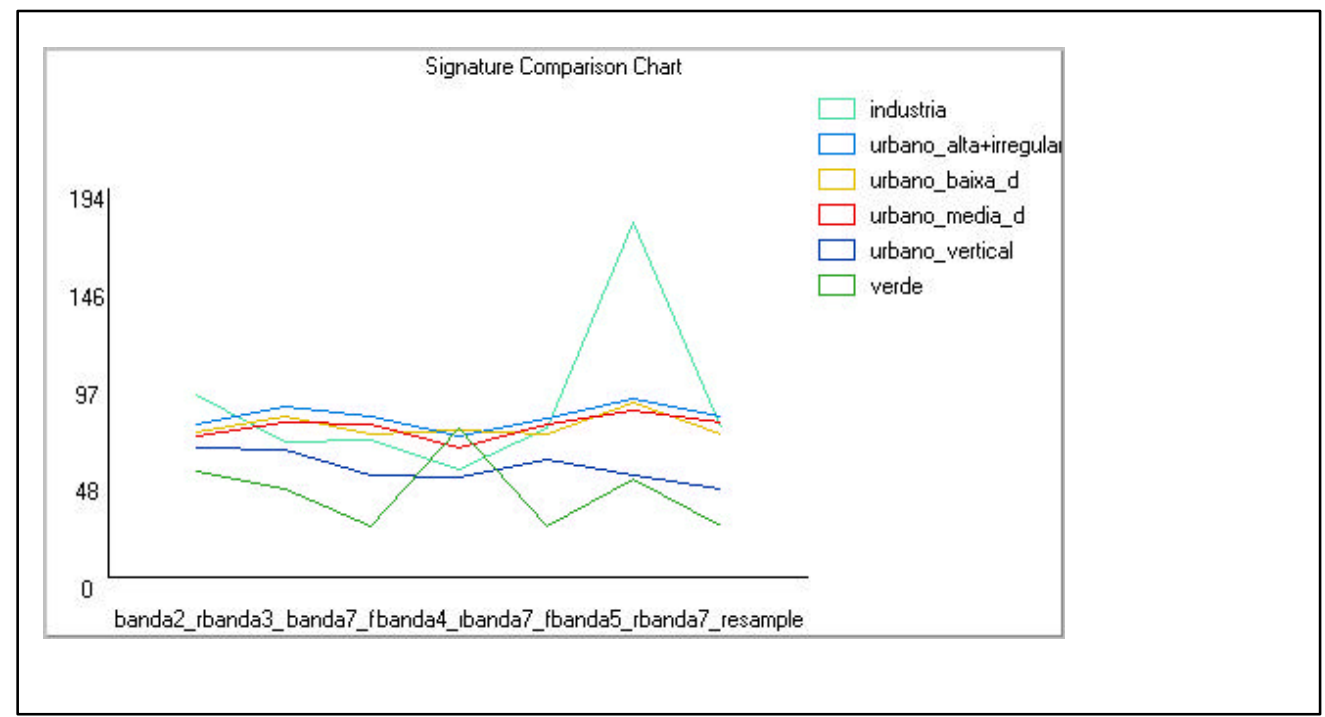

Figura 29 - Geração de níveis de cinza das classes a partir das amostras. 


\section{APLICAÇÃO DAS TÉCNICAS DE CLASSIFICAÇÃO}

Durante o desenvolvimento da metodologia diversas técnicas de classificação foram utilizadas, tendo sido realizada em diversas etapas, com o acréscimo e retirada de classes de uso do solo, de forma interativa, para que as classes de uso do solo mais representativas da região fossem selecionadas e que causassem a menor quantidade de erros. Cada interação foi comparada com a anterior, de modo a refinar as interações. Ao final de cada etapa, a matriz de erros de omissão e comissão e o índice Kappa eram comparados.

São apresentados a seguir três métodos de classificação desenvolvidos de modo interativo. Os dois primeiros são apresentados apenas como justificativa para o terceiro método.

\section{Classificação 1.}

Na primeira classificação realizada, foram adotados os seguintes procedimentos:

As classes Água e Vegetação são classes espectralmente homogêneas e de fácil obtenção, pois apresentam comportamento espectral específico.

Apesar disso, a separação da classe água apresentou-se mais complexa do que o esperado devido à poluição da água. Na imagem LANDSAT 7 de 1999, a água da represa apresentou uma mancha clara cuja composição não foi possível identificar.

$\mathrm{Na}$ classificação por máxima verossimilhança com todas as classes juntas, a classificação se mostrou muito ruim, pois a água não se apresenta homogênea, confundindo-se com outras classes.

Uma solução encontrada foi a separação somente da classe Água. Isso foi realizado através do fatiamento de histograma (slicer) de uma banda. Foi identificado o intervalo correspondente de nível de cinza da água pela análise visual a banda 7 , escolhida por apresentar melhor contraste, facilitando a separação desta classe. A classe água foi adicionada posteriormente, após a classificação por máxima verossimilhança das outras classes. 
A classe Vegetação também foi separada por esse processo. Esta classe foi analisada como uma classe única, sem subdivisão entre vegetação rasteira ou floresta. Inicialmente, não havia interesse em distinguir outras subclasses da vegetação.

Para a classificação das outras classes utilizou-se a Classificação Supervisionada por Máxima Verossimilhança. Foram retiradas amostras correspondentes as classes de interesse e utilizando-se o algoritmo de máxima verossimilhança obteve-se a classificação das classes restantes. As amostras foram retiradas com o auxilio das fotografias aéreas, que por estarem em uma escala melhor (1: 5.000), permitiram uma melhor delimitação das amostras, o que não melhora propriamente a classificação, mas tornam mais precisas as amostras de cada classe. Dois outros classificadores, o Paralelepípedo e a Distância Mínima foram testados não alcançando, porém resultados satisfatórios. As classes urbanas são complexas e de difícil separação, necessitando-se de análises cuidadosas, pois não apresentam elementos homogêneos e não podem ser bem expressas em uma classificação espectral somente.

As diversas classificações foram unidas obtendo-se o resultado apresentado na Figura 30 .

As assinaturas espectrais utilizadas na classificação supervisionada por máxima verossimilhança foram: indústria, classes urbanas de baixa, alta e média densidade, irregular e vertical.

Nesta primeira classificação (Figuras 30 e 31), pode-se observar diversas áreas não identificadas nas áreas vegetadas e áreas urbanas (em preto). 


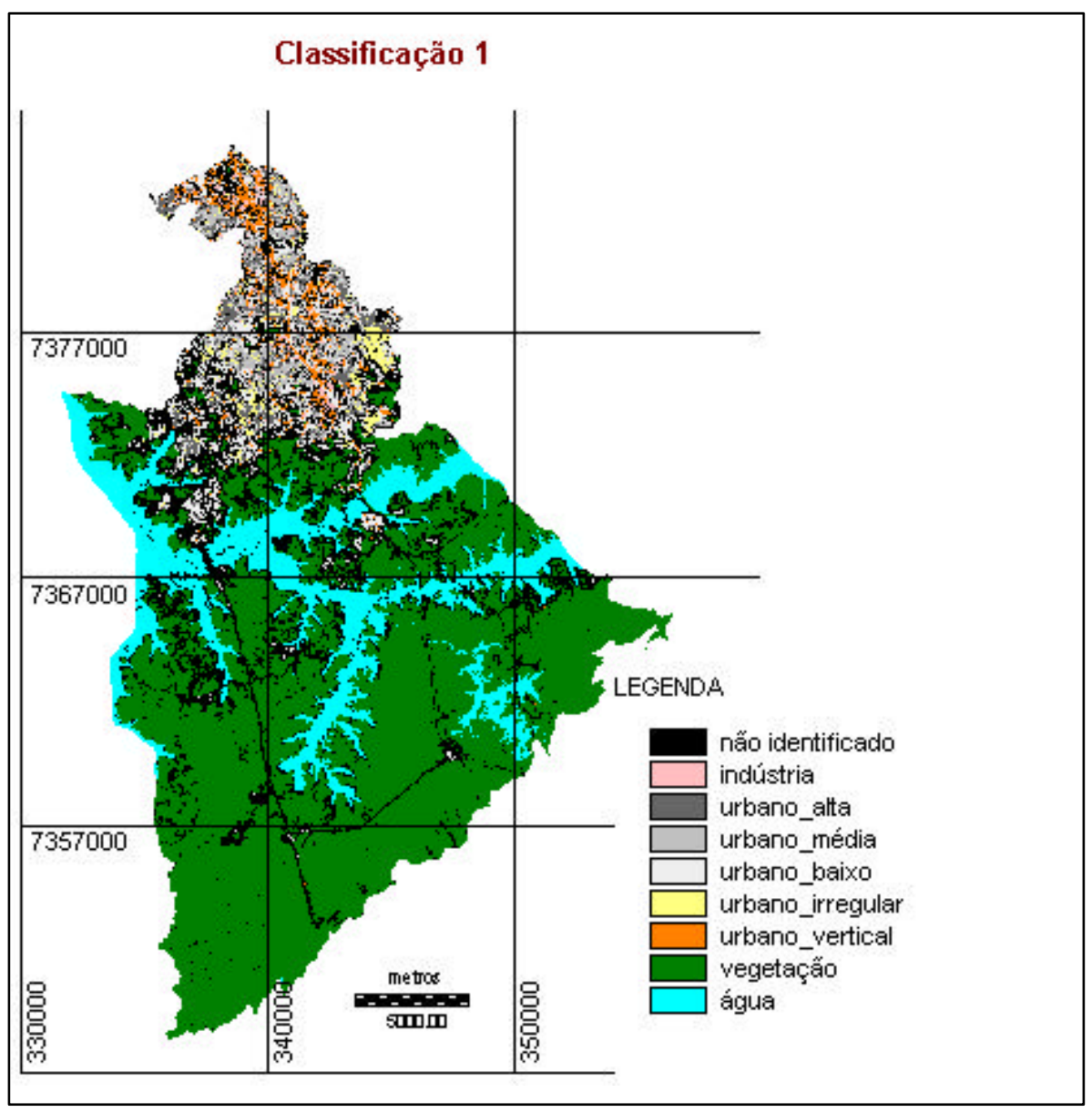

Figura 30 - Classificação 1

Pelas observações em campo, sabe-se que a classe Vegetação está distribuída de maneira não uniforme dentro das áreas urbanas. Nesta primeira classificação, não foi possível a sua identificação dentro das áreas urbanas. Muitas áreas de transição não foram corretamente classificadas.

A divisão desta classe em duas: vegetação rasteira e vegetação alta foi testada na Classificação 2. 


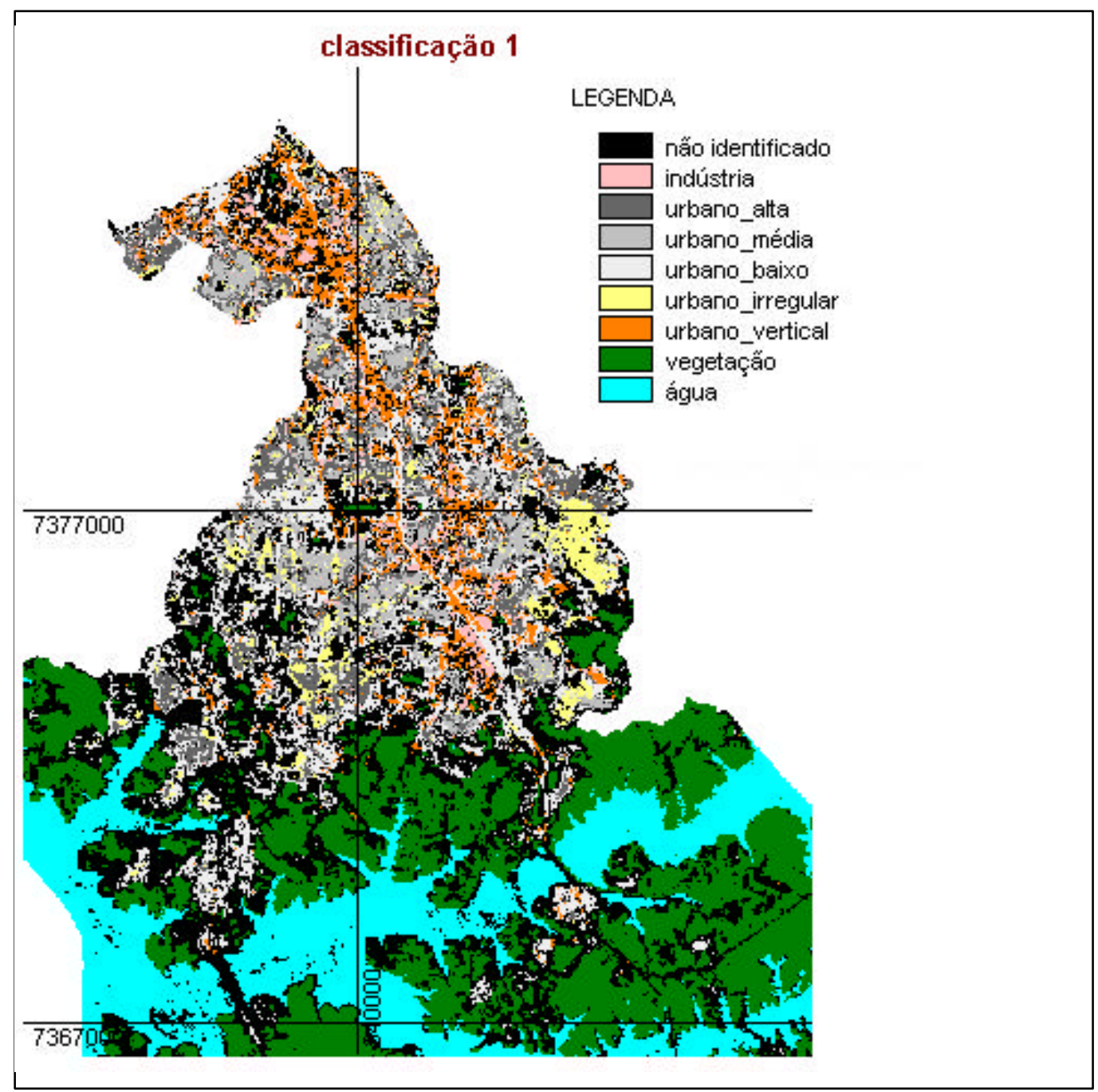

Figura 31 - Recorte ampliado da classificação 1

A matriz contendo os erros de omissão e comissão e o Índice Kappa desta classificação 1 podem ser observados na Tabela 19.

\section{Classificação 2:}

Água por fatiamento de histograma, vegetação e classes urbanas por algoritmo de Máxima Verossimilhança.

Novamente a classe água foi separada pelo fatiamento de histograma e utilizada depois na classificação.

Na Classificação 2 (Figura 32 e Figura 33), a classe vegetação foi dividida em duas subclasses: vegetação rasteira e vegetação (floresta). 


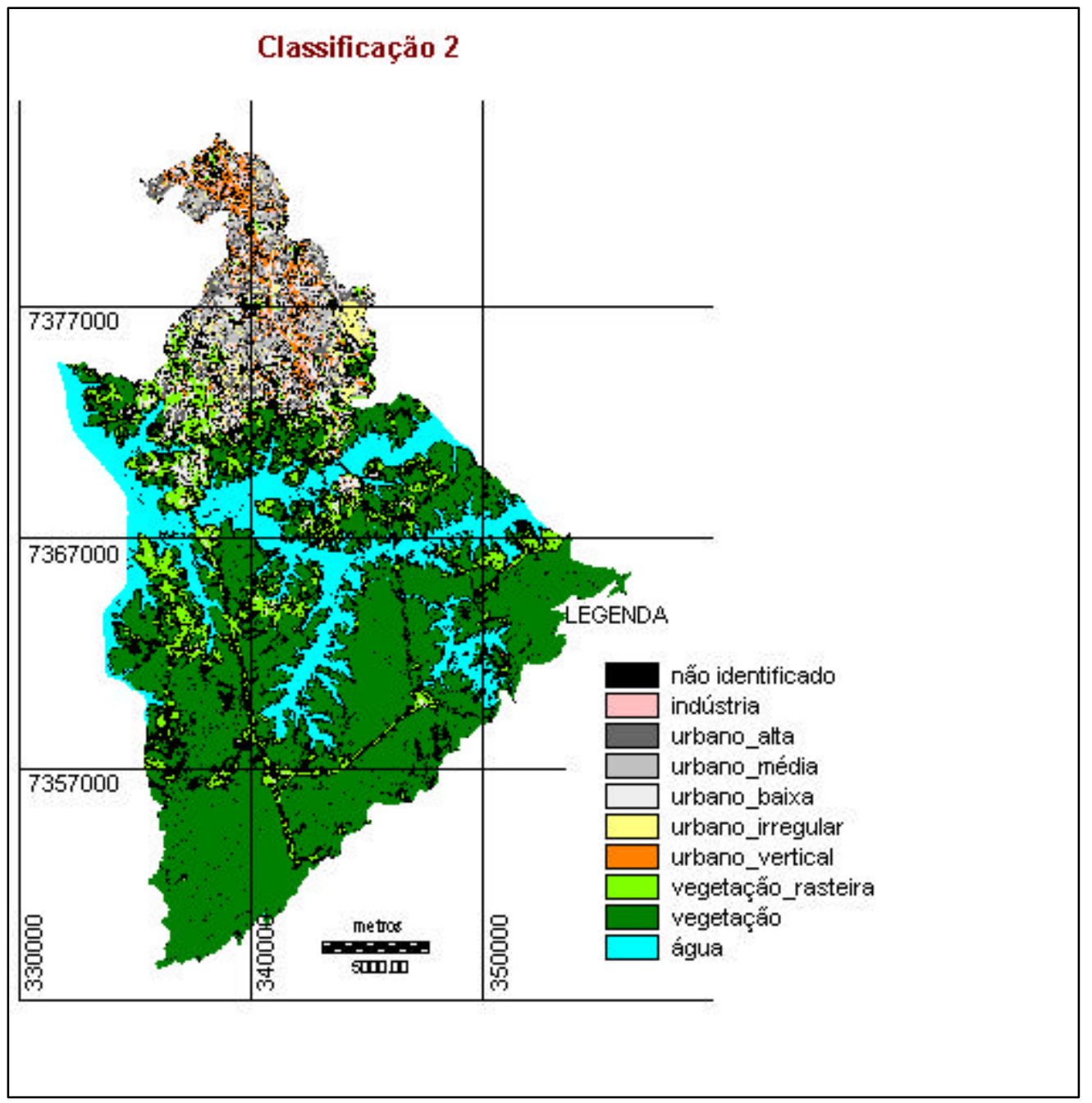

Figura 32 - Classificação 2

Observou-se que a subdivisão aumentava a qualidade da classificação das áreas urbanas, diminuindo a confusão entre elas. As áreas verdes existentes dentro das áreas urbanas (parques e jardins) não estavam sendo classificadas corretamente.

Apesar da classe vertical se mostrar bem distribuída na imagem, a análise visual mostrou diversas regiões classificadas erroneamente. As áreas urbanas multifamiliares de São Bernardo do Campo estão distribuídas ao longo das principais avenidas e nas imagens classificadas deveriam aparecem de forma linear, não como formas contínuas. Apesar destas áreas serem relacionadas às sombras dos edifícios, estas podem também estar associadas às outras classes. Esta classe foi retirada da classificação, pois como foi observado um padrão na sua distribuição é possível identificá-la sem necessidade de classificação. 


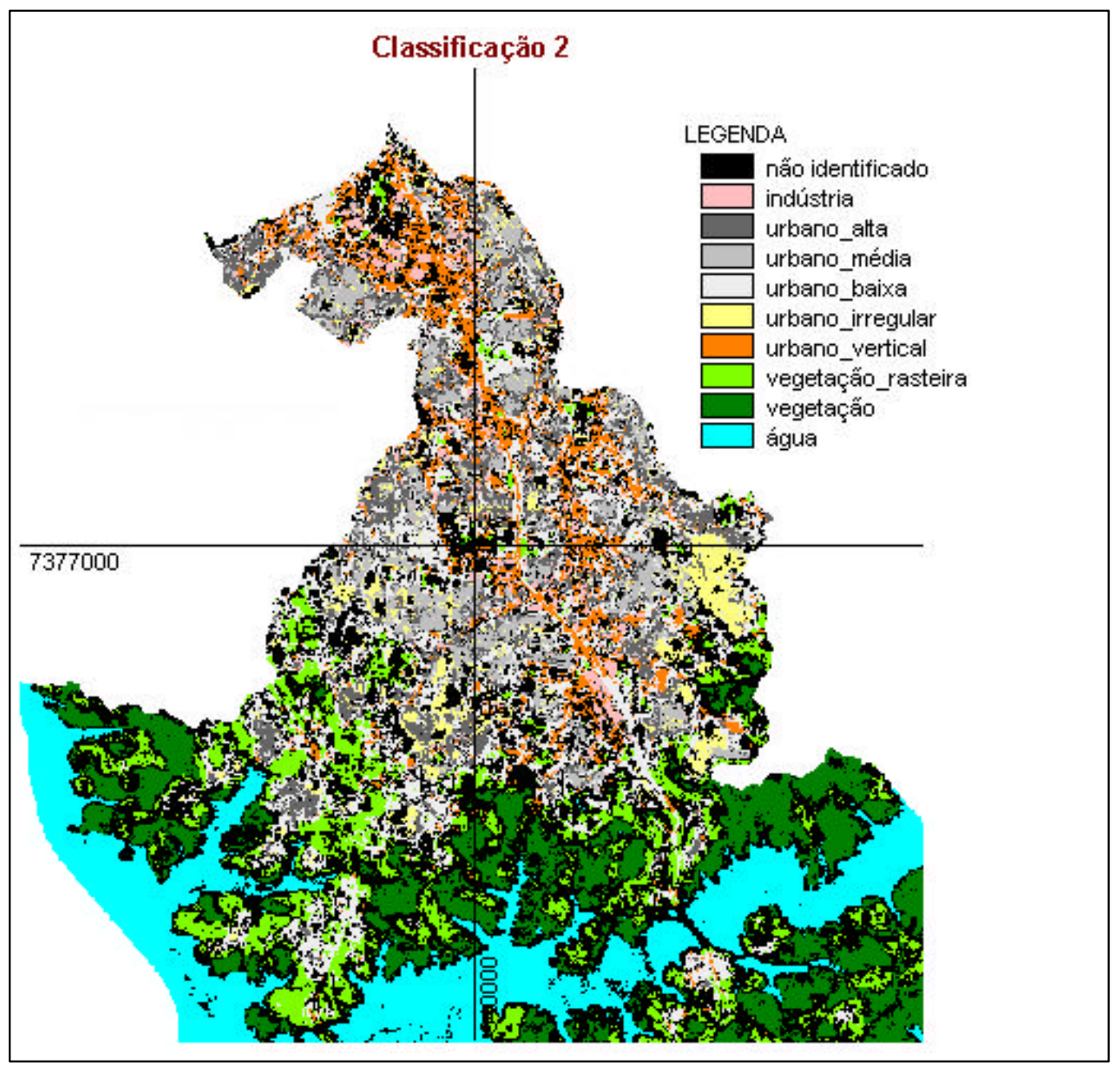

Figura 33 - Recorte ampliado da classificação 2

A classe Indústria resultou numa classe bem definida devido principalmente ao material construtivo específico (tipo de telhado), pelo aspecto físico (grande extensão, formatos regulares, presença de pátios) e à localização na cidade (concentração em algumas regiões da cidade).

A classe Sistemas Viários apresentou confusão com as outras classes e foi retirada do processo de classificação. Não foi possível a sua separação pelas várias técnicas utilizadas (fatiamento de histograma, classificação supervisionada por máxima verossimilhança, etc). As dificuldades foram causadas principalmente pela diferença dos materiais que compõe as duas principais vias de acesso à região, as Rodovias Anchieta e Imigrantes (são constituídas com diferentes composições de concreto e asfalto, respectivamente), e pela presença destas feições em outras classes de uso. 
Espectralmente, estes materiais apresentam características distintas dificultando a formação de uma única classe. As vias então foram identificadas pela linearidade. A inserção do mapa de sistema viário como um layer foi a solução para a distinção dessa classe. Além disso, a resolução espacial do sensor $(30 \mathrm{~m}$ no modo multiespectral) aumenta a confusão entre as classes.

As classes Urbano de Alta Densidade e Urbano Irregular mostraram-se difíceis de serem distinguidas separadamente. Então elas foram agrupadas em uma única classe, pois ambas as classes apresentam as mesmas características físicas e espectrais, isto é, loteamentos com as mesmas dimensões e mesmos padrões de distribuições com alta densidade ocupacional, ausência de áreas verdes como jardins, praças, quintais, etc.

Esta classificação foi realizada utilizando-se os mesmos processos descritos na classificação anterior, através da Classificação Supervisionada por Máxima Verossimilhança, com as classes: Vegetação Alta e Rasteira, Urbano Alta, Média e Baixa Densidade, Complexos Industriais e Comerciais e depois sobreposta com a classe água separada por fatiamento de histograma.

A matriz de erros de omissão e comissão e o índice Kappa estão na Tabela 20.

\section{Classificação 3 .}

Água por fatiamento e classes Vegetação e Urbana por algoritmo de Máxima Verossimilhança (união de algumas classes urbanas).

Para as necessidades de planejamento municipal da Prefeitura do Município de São Bernardo do Campo, o resultado apresentado encontra-se satisfatório (Figuras $34 \mathrm{e}$ 35). A resolução espacial das imagens LANDSAT $(30 \mathrm{~m})$ permite um nível de detalhe ideal às necessidades do planejamento municipal, obtendo-se uma visão global ou macro do município. A precisão quanto à separação das classes depende basicamente da finalidade de estudo. Para estudos cartográficos a precisão encontrada não é boa, porém para fins de planejamento, o resultado se encontra favorável. 
Os pixels não classificados em nenhuma das classes, foram agrupados numa única classe "Não identificada". Algumas áreas foram identificadas através do contexto. São áreas com um uso específico, não associado a qualquer classe amostrada, como o cemitério, os depósitos de lixo (lixão) e campos de golfe. Nesta classe, se encontraram regiões de transição que não se encaixavam em nenhuma das classes definidas e que apresentavam características espectrais diferentes.

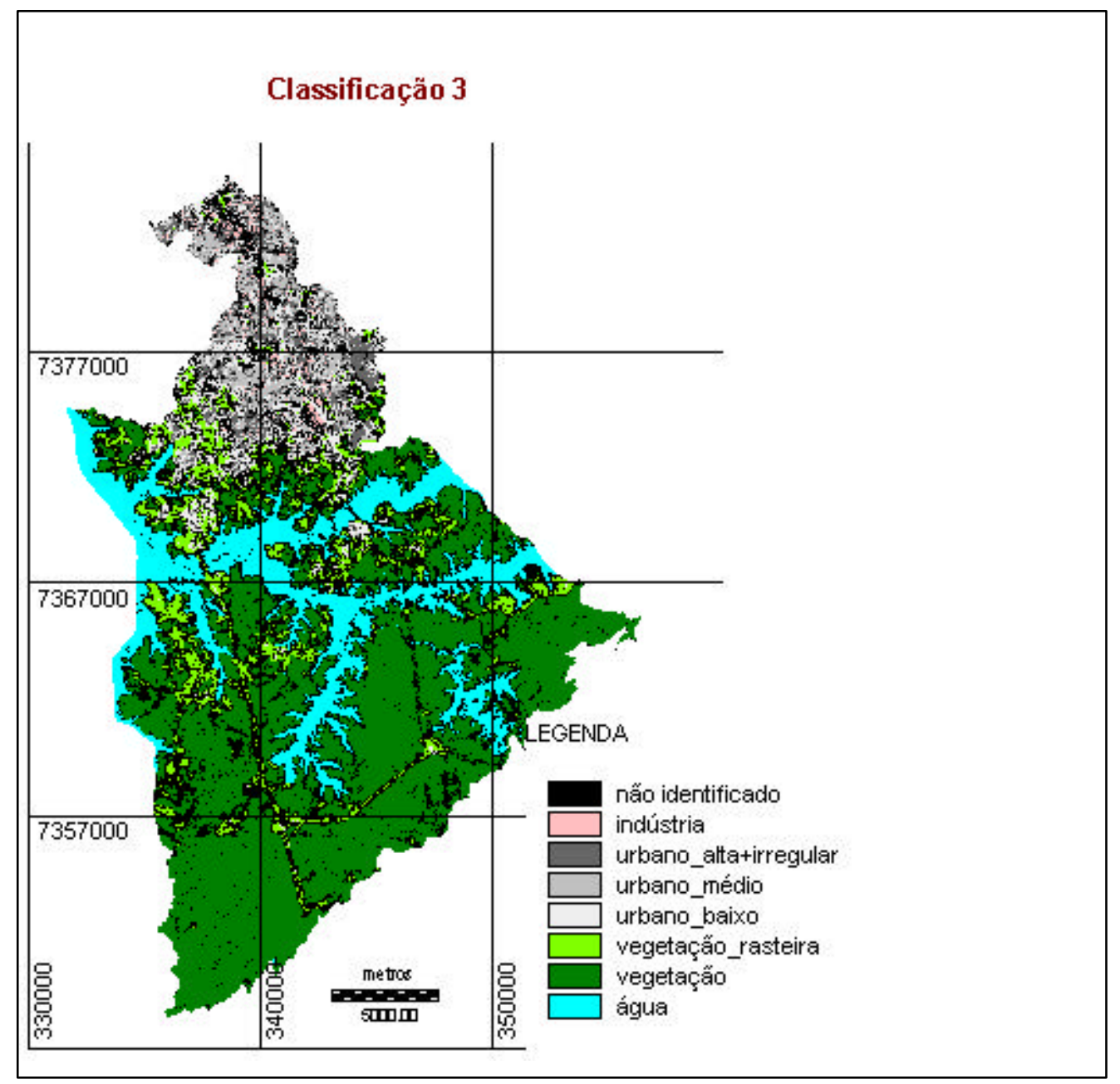

Figura 34 - Classificação 3 


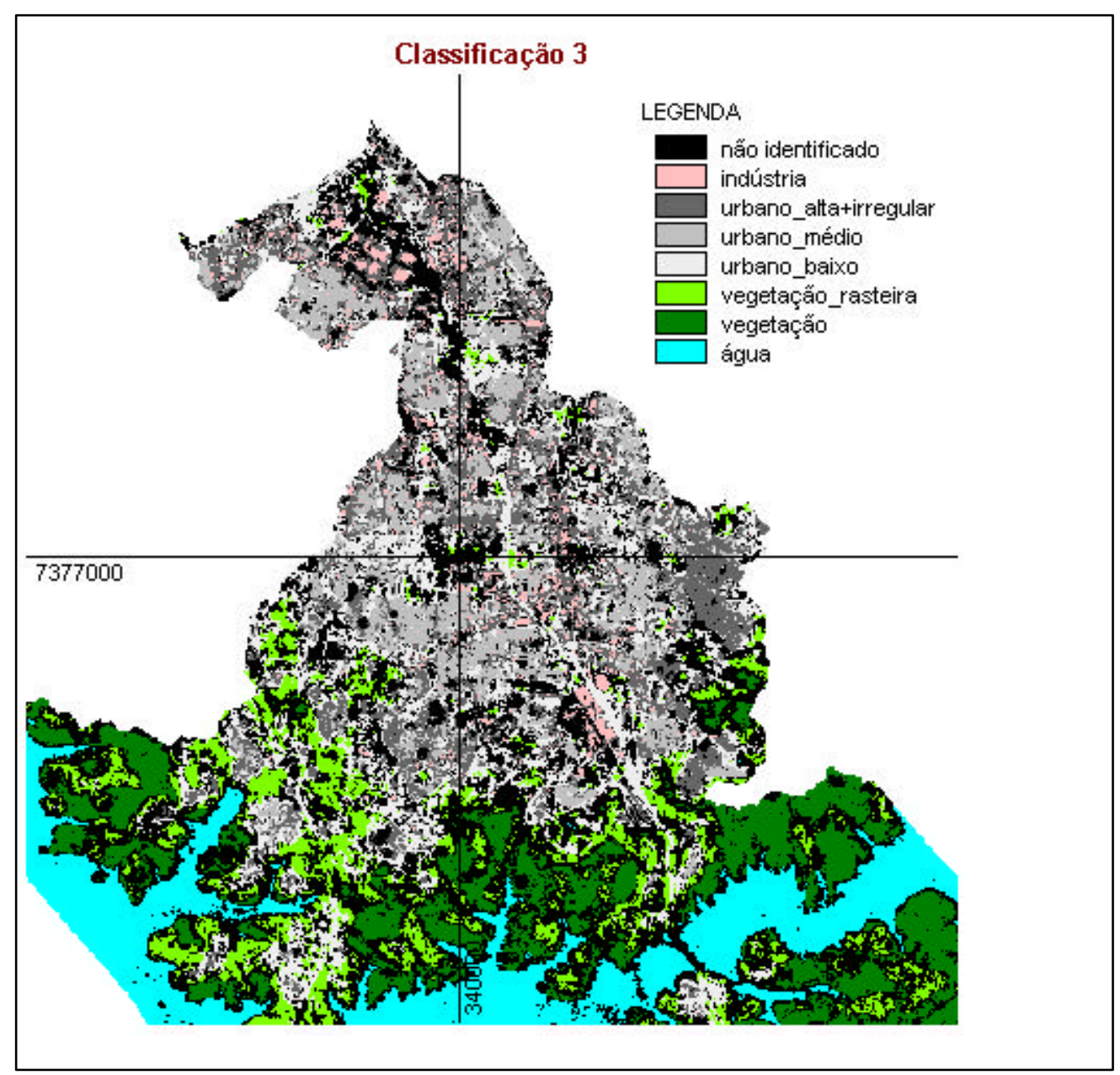

Figura 35 - Ampliação da classificação 3

O estágio final do processo de classificação consiste na análise da classificação. Foi verificado o erro da classificação, através da análise da matriz de erros.

Para a verificação dos erros de classificação foi necessária a comparação com a realidade no campo. Esta comparação foi feita através de visita à cidade e através das fotografias aéreas.

As Tabelas 19, 20 e 21 fornecem as matrizes de erros das classificações 1, 2 e 3 respectivamente, realizadas. Nestas tabelas, os números apresentados na diagonal 
principal (em vermelho), mostram a quantidade de pixels classificados de forma correta. Os números apresentados nas linhas são os pixels incluídos na classe de forma errada. E os números apresentados nas colunas, são os pixels excluídos de forma errada da classe.

O índice Kappa avalia a concordância entre a verdade terrestre e o mapa temático. Nas tabelas apresentadas (Tabelas 19, 20, 21), o índice Kappa foi fornecido para cada categoria de forma individual e de forma geral dando um resultado total. 


\section{Tabela 19 - Resultado da classificação 1}

Matriz de erros de omissão e comissão e índice Kappa obtidos através do software IDRISI3.2.

Error Matrix Analysis of GRUPO8 (columns : truth) against OVER_FUNDO_TUDO (rows : mapped)

\begin{tabular}{|c|c|c|c|c|c|c|c|c|c|c|c|}
\hline & 1 & 2 & 3 & 4 & 5 & 6 & 8 & 9 & 10 & Total & ErrorC \\
\hline 0 & 212 & 40 & 49 & 11 & 78 & 48 & 113 & 0 & 0 & 551 & 1.0000 \\
\hline 1 & 310 & 6 & 19 & 0 & 12 & 12 & 0 & 0 & 0 & 359 & 0.1365 \\
\hline 2 & 45 & 195 & 150 & 11 & 214 & 13 & 0 & 0 & 0 & 628 & 0.6895 \\
\hline 3 & 0 & 13 & 282 & 3 & 30 & 7 & 0 & 0 & 0 & 335 & 0.1582 \\
\hline 4 & 22 & 80 & 48 & 58 & 127 & 26 & 4 & 0 & 0 & 365 & 0.8411 \\
\hline 5 & 14 & 6 & 11 & 0 & 387 & 2 & 0 & 0 & 0 & 420 & 0.0786 \\
\hline 6 & 79 & 35 & 8 & 2 & 56 & 100 & 0 & 0 & 0 & 280 & 0.6429 \\
\hline 8 & 0 & 0 & 0 & 0 & 0 & 0 & 5256 & 0 & 0 & 5256 & 0.0000 \\
\hline 9 & 0 & 0 & 0 & 0 & 0 & 0 & 0 & 65645 & 0 & 65645 & 0.0000 \\
\hline 10 & 0 & 0 & 0 & 0 & 0 & 0 & 0 & 0 & 846471 & 846471 & 0.0000 \\
\hline Total & 682 & 375 & 567 & 85 & 904 & 208 & 5373 & 65645 & 846471 & 920310 & \\
\hline Erroro & 0.5455 & 0.4800 & 0.5026 & 0.3176 & 0.5719 & 0.5192 & 0.0218 & 0.0000 & 0.0000 & & 0.0017 \\
\hline
\end{tabular}

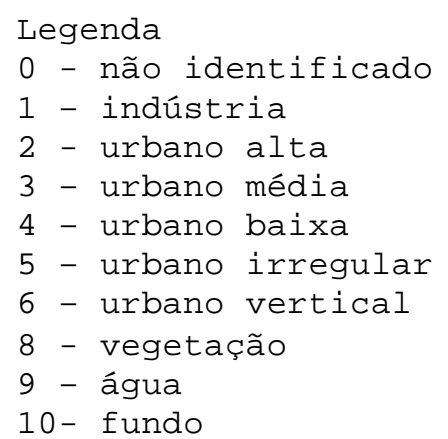


$\begin{array}{lll}\text { ErrorO } & =\text { Errors of Omission } & \text { (expressed as proportions) } \\ \text { ErrorC } & =\text { Errors of Commission } & \text { (expressed as proportions) }\end{array}$

$90 \%$ Confidence Interval $=+/-0.0001$

$95 \%$ Confidence Interval $=+/-0.0001$
$99 \%$ Confidence Interval $=+/-0.0001$

$(0.0017-0.0018)$

$(0.0017-0.0018)$

$(0.0016-0.0019)$

KAPPA INDEX OF AGREEMENT (KIA)

Using OVER_FUNDO_TUDO as the reference image ...

GRUPO8

$\begin{array}{rc}\text { Category } & \text { KIA } \\ 0 & 0.0000 \\ 1 & 0.8634 \\ 2 & 0.3102 \\ 3 & 0.8417 \\ 4 & 0.1588 \\ 5 & 0.9214 \\ 6 & 0.3570 \\ 8 & 1.0000 \\ 9 & 1.0000 \\ 10 & 1.0000\end{array}$

$\begin{array}{rr}\text { Category } & \text { K } \\ 1 & 0.4543 \\ 2 & 0.5197 \\ 3 & 0.4972 \\ 4 & 0.6822 \\ 5 & 0.4278 \\ 6 & 0.4806 \\ 8 & 0.9781 \\ 9 & 1.0000 \\ 10 & 1.0000\end{array}$


Tabela 20 - Resultados da classificação 2

Matriz de erros de omissão e comissão e índice Kappa obtidos através do software IDRISI3.2.

Error Matrix Analysis of OVERLAY_GRUPO5+FUNDO (columns : truth) against OVERLAY_FUNDO+AGURBREVE (rows : mapped)

\begin{tabular}{|c|c|c|c|c|c|c|c|c|c|c|c|c|}
\hline & 1 & 2 & 3 & 4 & 5 & 6 & 7 & 8 & 9 & 10 & Total & ErrorC \\
\hline 0 & 211 & 40 & 49 & 10 & 76 & 48 & 36 & 294 & 0 & 0 & 764 & 1.0000 \\
\hline 1 & 310 & 6 & 19 & 0 & 12 & 12 & 0 & 0 & 0 & 0 & 359 & 0.1365 \\
\hline 2 & 45 & 195 & 150 & 11 & 214 & 13 & 1 & 0 & 0 & 0 & 629 & 0.6900 \\
\hline 3 & 0 & 13 & 282 & 3 & 30 & 7 & 1 & 0 & 0 & 0 & 336 & 0.1607 \\
\hline 4 & 22 & 80 & 48 & 58 & 127 & 26 & 31 & 4 & 0 & 0 & 396 & 0.8535 \\
\hline 5 & 14 & 6 & 11 & 0 & 387 & 2 & 0 & 0 & 0 & 0 & 420 & 0.0786 \\
\hline 6 & 79 & 35 & 8 & 2 & 56 & 100 & 5 & 0 & 0 & 0 & 285 & 0.6491 \\
\hline 7 & 1 & 0 & 0 & 1 & 2 & 0 & 4 & 60 & 0 & 0 & 68 & 0.9412 \\
\hline 8 & 0 & 0 & 0 & 0 & 0 & 0 & 0 & 5015 & 0 & 0 & 5015 & 0.0000 \\
\hline 9 & 0 & 0 & 0 & 0 & 0 & 0 & 0 & 0 & 65645 & 0 & 65645 & 0.0000 \\
\hline 10 & 0 & 0 & 0 & 0 & 0 & 0 & 0 & 0 & 0 & 846471 & 846471 & 0.0000 \\
\hline Total & 682 & 375 & 567 & 85 & 904 & 208 & 78 & 5373 & 65645 & 846471 & 920388 & \\
\hline Erroro & 0.5455 & 0.4800 & 0.5026 & 0.3176 & 0.5719 & 0.5192 & 0.9487 & 0.0666 & 0.0000 & 0.0000 & & 0.0021 \\
\hline
\end{tabular}

legenda

0 - não classificado

1 - indústria

2 - urbano alta

3 - urbano média

4 - urbano baixa

5 - urbano irregular

6 - urbano vertical

7 - vegetação rasteira

8 - vegetação alta

9 - água

10- fundo 
Erroro = Errors of Omission (expressed as proportions)

ErrorC $\quad$ Errors of Commission (expressed as proportions)
$90 \%$ Confidence Interval $=+/-0.0001 \quad(0.0020-0.0022)$
$95 \%$ Confidence Interval $=+/-0.0001 \quad(0.0020-0.0022)$

$99 \%$ Confidence Interval $=+/-0.0001 \quad(0.0020-0.0022)$

KAPPA INDEX OF AGREEMENT (KIA)

Using OVERLAY_FUNDO+AGURBREVE as the reference image...

Category

KIA

$\begin{array}{rc} & \\ ----1 & -------- \\ 0 & 0.0000 \\ 1 & 0.8634 \\ 2 & 0.3097 \\ 3 & 0.8392 \\ 4 & 0.1464 \\ 5 & 0.9214 \\ 6 & 0.3507 \\ 7 & 0.0587 \\ 8 & 1.0000 \\ 9 & 1.0000 \\ 10 & 1.0000\end{array}$

Overall Kappa $=$

0.9860
OVERLAY_GRUPO5+FUNDO

\begin{tabular}{cc} 
Category & KIA \\
& \\
\hline 1 & 0.4543 \\
2 & 0.5197 \\
3 & 0.4972 \\
4 & 0.6822 \\
5 & 0.4278 \\
6 & 0.4806 \\
7 & 0.0512 \\
8 & 0.9330 \\
9 & 1.0000 \\
10 & 1.0000
\end{tabular}


Tabela 21 - Resultados da classificação 3

Matriz de erros de omissão e comissão e índice Kappa obtidos através do processamento no software IDRISI3.2.

Error Matrix Analysis of OVERLAY_FUNDO+GRUPO3 (columns : truth) against ovER_TUDO3 (rows : mapped)

\begin{tabular}{|c|c|c|c|c|c|c|c|c|c|c|}
\hline & 1 & 2 & 3 & 4 & 7 & 8 & 9 & 10 & Total & ErrorC \\
\hline 0 & 207 & 86 & 37 & 10 & 39 & 294 & 0 & 0 & 673 & 1.0000 \\
\hline 1 & 311 & 13 & 20 & 0 & 0 & 0 & 0 & 0 & 344 & 0.0959 \\
\hline 2 & 134 & 782 & 116 & 4 & 2 & 0 & 0 & 0 & 1038 & 0.2466 \\
\hline 3 & 4 & 182 & 352 & 7 & 1 & 0 & 0 & 0 & 546 & 0.3553 \\
\hline 4 & 25 & 214 & 42 & 63 & 32 & 4 & 0 & 0 & 380 & 0.8342 \\
\hline 7 & 1 & 2 & 0 & 1 & 4 & 60 & 0 & 0 & 68 & 0.9412 \\
\hline 8 & 0 & 0 & 0 & 0 & 0 & 5015 & 11 & 0 & 5026 & 0.0022 \\
\hline 9 & 0 & 0 & 0 & 0 & 0 & 0 & 65634 & 0 & 65634 & 0.0000 \\
\hline 10 & 0 & 0 & 0 & 0 & 0 & 0 & 0 & 846471 & 846471 & 0.0000 \\
\hline Total & 682 & 1279 & 567 & 85 & 78 & 5373 & 65645 & 846471 & 920180 & \\
\hline Erroro & 0.5440 & 0.3886 & 0.3792 & 0.2588 & 0.9487 & 0.0666 & 0.0002 & 0.0000 & & 0.0017 \\
\hline
\end{tabular}

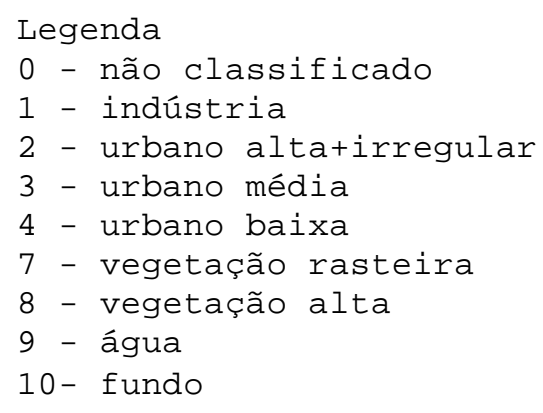




$\begin{array}{llll}\text { Erroro } & =\text { Errors of Omission } & \text { (expressed as proportions) } \\ \text { ErrorC } & =\text { Errors of Commission (expressed as proportions) }\end{array}$

\begin{tabular}{|c|c|c|c|c|c|}
\hline & rval & $+1-$ & 0.0001 & 10.0016 & $0.0018)$ \\
\hline $\mathrm{Cor}$ & Interval & $+1-$ & 0.0001 & 10.0016 & -0 . \\
\hline idence & Interval & $+1-$ & 0.0001 & 10.0016 & $-0.0018)$ \\
\hline
\end{tabular}

KAPPA INDEX OF AGREEMENT (KIA)

Using OVER_TUDO3 as the reference image ... OVERLAY_FUNDO+GRUPO3

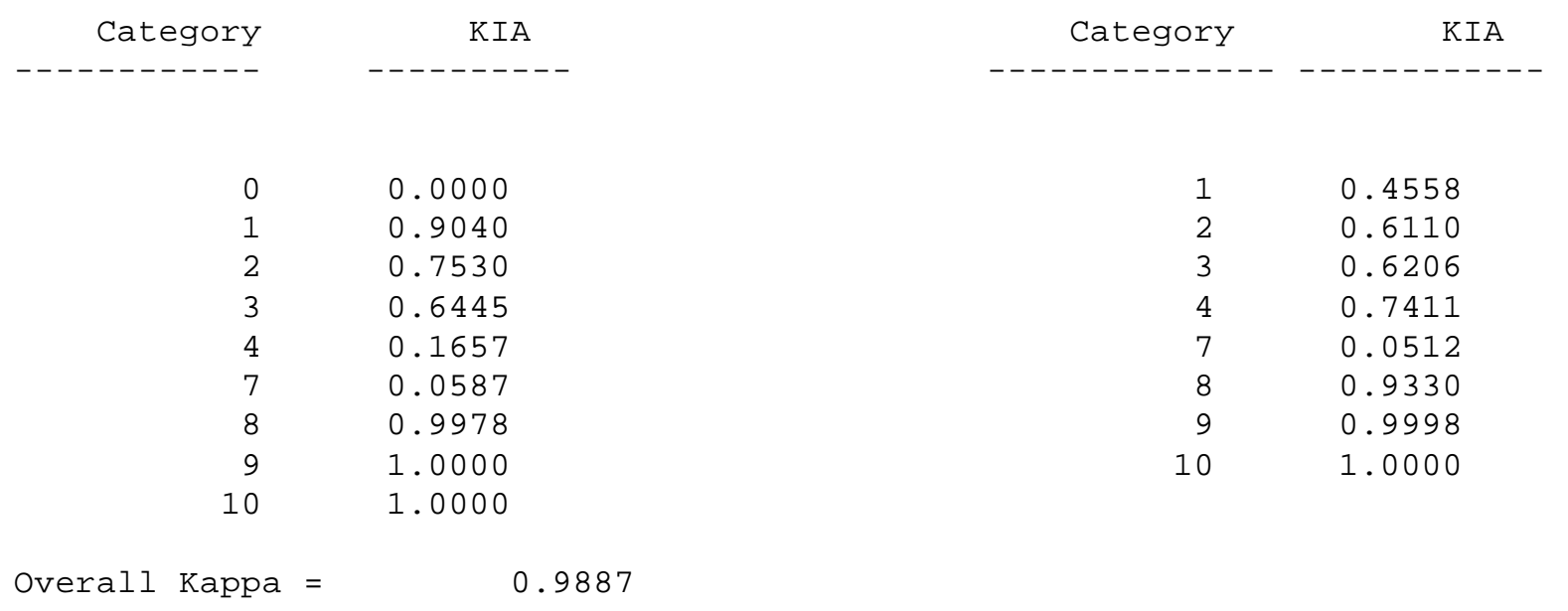


Tabela 22 - Resumo dos resultados

\begin{tabular}{|c|c|c|c|}
\hline Categoria & \multicolumn{3}{|c|}{ Índice Kappa } \\
\hline & CLASSIF. 1 & CLASSIF.2 & CLASSIF.3 \\
\hline 1 & 0,4543 & 0,4543 & 0,4558 \\
\hline 2 & 0,5197 & 0,5197 & 0,6110 \\
\hline 3 & 0,4972 & 0,4972 & 0,6206 \\
\hline 4 & 0,6822 & 0,6822 & 0,7411 \\
\hline 5 & 0,4278 & 0,4278 & \\
\hline 6 & 0,4806 & 0,4806 & 0,0512 \\
\hline 7 & & 0,0512 & 0,9330 \\
\hline 8 & 0,9781 & 0,9330 & 0,9998 \\
\hline 9 & 1,0000 & 1,0000 & 0,9887 \\
\hline & & & \\
\hline TOTAL & 0,9883 & 0,9860 & \\
\hline
\end{tabular}

Nas classes urbanas, diversos pixels foram classificados erroneamente, como era de se esperar devido à grande variabilidade espectral existente nestas áreas. As piores classes foram as classes de alta e média densidade, irregulares e verticais (Tabela 19, 20 e 21$)$.

Para as áreas irregulares a maior confusão foi com a classe de alta densidade. Com a união destas duas classes (Classificação 3 - Tabela 21) houve uma significativa melhora na classificação.

Os índices Kappa individuais melhoraram com a união das classes alta e irregular e com a exclusão da classe vertical (Tabela 20).

A classe vegetação rasteira, apesar de apresentar erros de omissão e comissão grandes, aumentou a distinção visual das classes. Esta classe se encontra presente em quase todas as outras classes, na forma de jardins, canteiros, e pequenos parques, daí a melhora na classificação.

O resumo dos resultados (Tabela 22) indica que o valor global de índice Kappa apresentou uma pequena, porém significativa melhoria na classificação 3 . 


\section{ANÁLISE DOS RESULTADOS DA CLASSIFICAÇÃo}

O que se pode observar em visitas à região e através dos resultados da classificação da imagem de satélite, é que as classes urbanas de alta densidade e as irregulares apresentam padronizações na construção. Os materiais utilizados nas construções das casas são os mesmos, as dimensões dos lotes variam muito pouco. Esta padronização torna a classe quase homogênea observando-se uma pequena variabilidade, o que reforça o que a bibliografia costuma sugerir para classificações intra-urbanas com imagens desta resolução.

As áreas verticalizadas se confundem com outras feições devido à presença da sombra, que está presente em quase todas as classes, o que dificulta a sua separação em uma única classe específica. Estas áreas urbanas verticalizadas localizam-se principalmente ao longo das principais vias (Anchieta e Imigrantes), formando assim, feições lineares, fáceis de serem visualizadas, o que permitiu a sua eliminação no processo de classificação automática.

As áreas industriais e comerciais se concentram em regiões determinadas no município. Sua localização é facilitada pelos padrões construtivos que se destacam nas imagens: grandes dimensões, formatos regulares, presença de pátios e estacionamentos, material construtivo.

As regiões ao redor da represa são as que necessitaram de cuidados maiores. O que se notou foi a intensa invasão de regiões próximas à represa. Áreas assoreadas presentes ao redor da represa foram ocupadas, representando um grande perigo à população ocupante dessas áreas, além do impacto ambiental que essa invasão representa.

Das técnicas utilizadas na classificação do município, a classificação supervisionada por máxima verossimilhança mostrou-se bastante eficiente no mapeamento do uso do solo. A filtragem de uma banda utilizada na classificação diminuiu a variabilidade espectral das áreas urbanas, permitindo a formação de classes intra-urbanas. A retirada de amostras através das fotografias aéreas em formato digital e o prévio conhecimento da região pelos técnicos do município contribuíram para que as 
amostras retiradas para análise fossem bem características de cada classe, diminuindo assim o erro na classificação.

O município de São Bernardo do Campo apresenta características que permitem a formação de zonas homogêneas, isto é, as classes são razoavelmente definidas. As áreas não classificadas eram áreas de transição não pertencentes a nenhuma classe definida.

Através da metodologia desenvolvida, foi possível perceber que a utilização de imagens de satélite como ferramenta para o planejamento do município é muito útil, pois fornecem uma visão global e macro do município. As distribuições dos diversos usos do solo podem ser identificadas. $\mathrm{O}$ entendimento das imagens e suas informações representam importante ferramenta para o processo de mapeamento e preciosa fonte de informação que pode ser utilizada no planejamento e monitoramento da cidade.

Pelas classificações realizadas foi possível perceber também que grandes áreas protegidas por lei, já estão ocupadas por favelas ou loteamentos clandestinos. Estas formas de ocupação são as piores possíveis para uma região estratégica ao abastecimento de água, pois são ocupações extremamente agressivas ao meio ambiente, pois não possuem infra-estrutura, e esgoto e lixo são jogados diretamente nos mananciais sem qualquer tratamento. Sendo áreas estratégicas para o abastecimento de água da cidade, estas ocupações crescentes são preocupantes.

Estas invasões apesar de identificadas pelo poder público não tem sido suficientemente contidas, gerando uma sensação de impunidade que, por sua vez, estimula a ocorrência de novas agressões.

A participação dos municípios que integram a bacia hidrográfica da Billings no planejamento urbano é a melhor forma de encontrar soluções para a difícil tarefa de gerenciar o crescimento urbano destes municípios e impedir a degradação deste importante manancial. 


\section{CONCLUSÃO}

Para a região escolhida, a metodologia atingiu o objetivo proposto que era $\mathrm{o}$ mapeamento do uso do solo urbano da região e a identificação de regiões onde as classes escolhidas se concentravam. Neste sentido, os resultados obtidos pela classificação mostraram que as classes escolhidas formam "manchas" concentradas em regiões determinadas do município, formando zonas homogênea e possíveis de serem identificadas pelo mapeamento com imagens de satélite. A utilização de imagens de satélite como ferramenta para o planejamento do município mostrou-se bastante eficaz, fornecendo uma visão global do município.

A aplicação de técnicas de processamento como a filtragem de uma banda e a utilização como uma banda adicional, mostrou-se eficiente para a formação de zonas diferenciadas nas áreas urbanas, já que os filtros utilizados diminuem a variabilidade espectral destas classes. Assim, a utilização desta técnica é recomendável para outros trabalhos.

As principais vantagens demonstradas pela metodologia desenvolvida foram:

Custo: as imagens do satélite LANDSAT 7 utilizadas no trabalho, são de custo relativamente baixo (em comparação com imagens de outros sensores ou as fotografias aéreas), além disso, abrangem áreas extensas, que na região de estudo, á um fator importante, pela sua extensão.

Técnicas consagradas no meio cientifico: as técnicas utilizadas na metodologia são conhecidas no meio acadêmico e utilizadas em diversos trabalhos relacionados a classificação de imagens.

Fácil aplicação: as técnicas e os conceitos foram transmitidos aos técnicos da prefeitura do município de São Bernardo do Campo que participaram do projeto inicial e sempre que possível, são aplicadas nas atividades do dia-a-dia. Entretanto, na prefeitura, a metodologia não tem sido muito utilizada nos trabalhos relativos ao planejamento urbano por causa das mudanças estruturais que ocorreram na prefeitura. Porém, uma vez desenvolvida a metodologia e conhecidas as técnicas, estes podem ser utilizados a qualquer momento e com a utilização de informações recentes e imagens atualizadas. 
As desvantagens da metodologia foram:

Resolução do sensor: a resolução do sensor limita determinados estudos como detalhamento das áreas urbanas não permitindo esse nível de detalhe (resolução espacial de 30 m no modo multiespectral do sensor do Satélite LANDSAT7).

Conhecimento prévio da área: há a necessidade de conhecimento prévio da região para a seleção das classes e amostras a serem estudadas. Além disso, cada região possui particularidades que devem ser conhecidas para que a metodologia seja mais eficiente.

Trabalhos futuros

Com o surgimento de novos sensores, com melhor resolução espacial (IKONOS com $1 \mathrm{~m}$ de resolução espacial, por exemplo), diversos e variados estudos nas áreas urbanas podem ser desenvolvidos e outras técnicas podem ser utilizadas.

A metodologia desenvolvida pode ser aplicada em outras regiões. Entretanto, o conhecimento prévio da região é necessário, pois cada região apresenta particularidades, porém os princípios utilizados no desenvolvimento da metodologia são os mesmos e as etapas e as técnicas podem ser repetidas para as diversas regiões.

Na escolha das imagens para os trabalhos, a época do ano é importante. Dependendo da época do ano da imagem alguns alvos são identificados de maneira mais eficiente do que outros. 


\section{REFERÊNCIAS BIBLIOGRÁFICAS}

ANDERSON, J. R.; et al. Sistemas de classificação de uso da terra e do revestimento do solo para utilização com dados de sensoriamento remoto. Trad. de H. Strang., Rio de Janeiro: IBGE, 1976, 78p.

BARALDI, A.; PARMIGGIANI, F. Urban area classification by multispectral SPOT data. IEEE Transactions on Geoscience and Remote Sensing, New York, v. 28, n.4, p. 674-680, Jul., 2000.

BROWN, D. G. Classification and boundary vagueness in mapping presettlement forest types. International Journal of Geographical Information Science, London, v. 12, n. 2, p. 105-129, Mar., 1998.

COSTA, S. M. F. Avaliação de técnicas de processamento digital de imagens TM-LANDSAT aplicadas à delimitação de áreas urbanas. 1989. 110p. Dissertação (Mestrado) - Instituto de Pesquisas Espaciais, INPE. São José dos Campos, 1989.

COSTA, S. M. F. Metodologia alternativa para o estudo do espaço metropolitano, integrando as tecnologias de SIG e sensoriamento remoto: aplicação a área metropolitana de Belo Horizonte. 1996. 179p. Tese (Doutorado) - Escola Politécnica, Universidade de São Paulo. São Paulo, 1996.

COULOMBE, A.; et al. L'apport de l'analyse textural dans la definition de l'utilization du sol en millieu urbain. Canadian Journal of Remote Sensing, Ottawa, v. 7, n. 1, p. 46-55, Jan., 1991.

CRÓSTA, A. P. Processamento digital de imagens de sensoriamento remoto. Campinas: Unicamp, 1992. 170p.

FERRARI, C. Curso de planejamento municipal integrado, 6. ed. São Paulo: Pioneira, 1988. 631p.

FORESTI, C. Avaliação e monitoramento ambiental da expansão urbana do setor oeste da área metropolitana de São Paulo: através de dados e técnicas de 
sensoriamento remoto. 1986. 178p. Tese (Doutorado) - Geografia Física, Universidade de São Paulo. São Paulo, 1986.

. Estimativas populacionais e de crescimento de áreas urbanas no estado de São Paulo, com a utilização de imagens LANDSAT. 1978. 115 p. Dissertação (Mestrado) - Instituto de Pesquisas Espaciais, INPE. São José dos Campos, 1978.

FORSTER, B.C. An examination of some problems and solutions in monitoring urban areas from satellite platforms. International Journal of Remote Sensing, London, v. 6, n. 1, p. 139-151, Jan., 1985.

FORSTER, B.C.; JONES, C. Urban density monitoring using high resolution spaceborne systems. In: INTERNATIONAL ARCHIVES OF PHOTOGRAMMETRY AND REMOTE SENSING. V.XXIX part VII, Commission 7, International Symposium on Photogrammetry and Remote Sensing, XIXth Congress, Kyoto, 1988, p. 189-195.

GONG, P; HOWART, P.J. The use of structural information for improving land cover classification accuracies at the rural-urban fringe. Photogrammetric Engineering and Remote Sensing, Washington, v. 56, n. 1, p. 67-73, Jan., 1990.

GONZAlEZ, R. C.; WOODS, R. E. Processamento de imagens digitais. São Paulo: Edgard Blucher, 2000. 509 p.

HARALICK, R.M. Statistical and structural approaches to texture. Proceedings of the IEEE, v. 232, n. 4, p. 34-43, May 1975.

HARRIS, P. M.; VENTURA, S. J. The integration of geographic data with remotely sensed imagery to improve classification in an urban area. Photogrammetric Engineering and Remote Sensing, Washington, v. 61, n. 8, p. 993-998, Aug., 1995.

HAYKIN, S. Neural Networks - A Comprehensive Foundation. New York: Macmillan , 1994. 696p.

IBGE, Introdução ao Processamento Digital de Imagens. Manual técnico em geociênciais, Rio de Janeiro, n. 9, 2001. 92p 
IOKA, M. and KODA, M. Performance of LANDSAT TM data in land cover classification. International Journal of Remote Sensing, London, v. 7, n. 12, p. 1715-1728, Aug., 1986.

IRON, J. R.; PETERSEN, G. W. Texture transforms of remote sensing data. Remote Sensing of Environment, New York, v. 11, n. 8, p. 359-370, Aug., 1981.

JACKSON, M.J.; et al. Urban land mapping from remotely sensed data. Photogrammetric Engineering and Remote Sensing, Washington, v. 8, n. 46, p. 1041-1050, Aug., 1980.

JENSEN, J. R. Urban/suburban land use analysis. In: Manual of remote sensing v.2. $2^{\text {nd }}$ ed. Falls Church, V. A: American Society of Photogrammetry, 1983. p. 1571-1666.

Introductory digital image processing. New Jersey: Prentice-Hall, 1986. 379 p.

KUMAR, A S.; BASU, S. K.; MAJUMDAR, K. L. Robust classification of multispectral data using multiple neural networks and fuzzy integral. IEEE Transactions on Geoscience and Remote Sensing, New York, v. 35, n. 3, p. 787790, May, 1997.

KURKDJIAN, M. L. O; II, S. S. Integração de imagens SPOT multiespectral e aerofoto pancromático para estudo do uso do solo urbano. In: SIMPÓSIO LATINO AMERICANO DE PERCEPTION REMOTA, 4; Bariloche, 1989. Proceedings. Bariloche: SELPER, 1989. p.415-421.

LANDIS, J.; KOCH, G.G. The measurements of observer agreement for categorical data. Biometrics, Washington, v. 33, n. 3, p.159-174, mar., 1977.

LILLESAND, T. M.; KIEFER, R. W. Remote Sensing and Image Interpretation. 2. ed. New York: Wiley \& Sons. 1987, 721p. 
LOMBARDO, M. A.; MACHADO, R. P. P. Aplicação das técnicas de sensoriamento remoto e sistemas de informação geográfica nos estudos urbanos. Revista do Departamento de Geografia, São Paulo, n.10, p.5-11, 1996.

MANSO, A. P.; OLIVEIRA, M. L. N.; BARROS, M. S. S. Determinação de zonas homogêneas através de sensoriamento remoto. São José dos Campos: Instituto Nacional de Pesquisas Espaciais, 1979. Relatório Técnico. 35p.

MARCONDES, M. J. A. Urbanização e meio ambiente: os mananciais da metrópole paulista. 1995. 337p. Tese (Doutorado) - Faculdade de Arquitetura e Urbanismo da Universidade de São Paulo. São Paulo, 1995.

Cidade e natureza: proteção aos mananciais e exclusão social. São Paulo: Studio Nobel/ EDUSP/ FAPESP, 1999. 238p.

MARTIN, L. R.; HOWARTH, P.J.; HOLDER, G. Multispectral classification of land use at the rural-urban fringe using SPOT data. Canadian Journal of Remote Sensing, Ottawa, v. 14, n. 2, p. 72-79, Apr., 1988.

MOLLER-JENSEN, L. Knowledge-based classification of an urban area using texture and context information in LANDSAT TM imagery. Photogrammetric Enginering and Remote Sensing, Washington, v 56, p. 899-904, 1990.

MOREIRA, M. A. Fundamentos do sensoriamento remoto e metodologias de aplicação. São José dos Campos: INPE, 2001. 250 p.

NOVO, E. M. L. de M. Sensoriamento remoto: princípios e aplicações, São Paulo: Edgar Blücher, 1995. 2.a ed. 308p.

PAOLA, J. D.; SCHOWENGERDT, R. A A detailed comparison of back propagation neural networks and maximum likelihood classifiers for urban land use classification. IEEE Transation on Geoscience and Remote Sensing, New York, v. 33, n. 4, p. 981-996, Jul., 1995. 
PEREIRA, M. N.; KURKDJIAN, M.L.O.; FORESTI, C. Cobertura e uso da terra através de sensoriamento remoto. Technical Paper, São José dos Campos: INPE, $1985,126 \mathrm{p}$.

PREFEITURA DO MUNICÍPIO DE SÃO BERNARDO DO CAMPO. Compêndio Estatístico. São Bernardo do Campo: Prefeitura do município de São Bernardo do Campo, 1998.

QUINTANILHA, J. A.; et al. The use of remote sensing in the monitoring of the metropolitan area in São Bernardo do Campo, Brazil. In: URBAN AND REGIONAL DATA MANAGEMENT SYMPOSIUM, 22., Delft, 2000a. Proceedings. Delft : Urban Data Management Society, 2000. v. 5, p. 530-559

QUINTANILHA, J. A.; HAMBURGER, D. S.; IWAI, O. K. Technology transfer in digital image processing techniques. In: INTERNATIONAL IT CONFERENCE ON GEO SPATIAL EDUCATION, Hong Kong, 2000b. Proceedings. Hong Kong: Hong Kong Polytechnic University, 2000. 230 p.

QUINTANILHA, J. A.; LIMA, R. A. F.; HAMBURGER, D. S. Introdução ao processamento digital de imagens. In: PROGRAMA DE TRANSFERÊNCIA DE TECNOLOGIA GIS, 3, São Paulo, 1998a. MATERIAL DIDATICO. São Paulo: SABESP/EPUSP, 1998, 28 p. Em CD-Rom

QUINTANILHA, J. A.; LIMA, R. A. F.; HAMBURGER, D. S. Princípios de sensoriamento Remoto. In: PROGRAMA DE TRANSFERÊNCIA DE TECNOLOGIA GIS, 1. São Paulo, 1998b. MATERIAL DIDÁTICO. São Paulo: SABESP/EPUSP, 1998. 28 p. Em CD-Rom.

SECRETARIA DO ESTADO DO MEIO AMBIENTE; CETESB; SECRETARIA DE RECURSOS HÍDRICOS SANEAMENTO E OBRAS; SABESP, GOVERNO DO ESTADO DE SÃO PAULO. Termo de referência para o Programa de Recuperação Ambiental da Bacia da Billings. Technical Report, São Paulo. Julho 1999. 
TAGNIN, R. A. O tratamento da expansão urbana na proteção aos mananciais: o caso da região metropolitana de São Paulo. 2000. 291p. Dissertação (mestrado). Escola Politécnica, Universidade de São Paulo. São Paulo, 2000.

TARDELLI FILHO, J. Fundamentos e metodologia de proteção aos mananciais através do disciplinamento do uso e ocupação do solo. 1987. 260p. Dissertação (Mestrado). Escola Politécnica, Universidade de São Paulo. São Paulo, 1987.

TEIXEIRA, A. L.A; CHRISTOFOLETTI, A. Sistemas de Informação Geográfica. Dicionário Ilustrado. São Paulo: Editora Hucitec, 1997. 244p.

URBANA, T. A Região Metropolitana de Curitiba, o meio ambiente e a água. Caderno de Gestão Urbana, Curitiba, v.1, p.53-65, dez, 1999.

VOGELMANN, J. E.; SOHL, T.; HOWARD, S. M. Regional characterization of land cover using multiple sources of data. Photogrammetric Engineering and Remote Sensing, Washington, v. 64, n. 1, p. 45-57, Jan., 1998.

\section{ACESSO ONLINE:}

ANIELLO, C; et al. Mapping micro-urban heat islands using LANDSAT TM e GIS Computers \& Geosciences, v.21, n. 8, p. 965-969, Oct., 1995. Disponível em: <http://e5500.fapesp.br/pdflinks/03022416551708038.pdf〉. Acesso em: 24 mar. 2003.

\section{ASTER. Instrument Characteristics}

Disponível em: 〈http://asterweb.jpl.nasa.gov/instrument/character.htm>. Acesso em: 17 nov. 2002.

ATKINSON, P. M.; LEWIS, P. Geostatistical classification for remote sensing: an introduction. Computers \& Geosciences, v.26, n. 4, p. 361-371, May, 2000. Disponível em: <http://e5500.fapesp.br/pdflinks/03032819322913901.pdf〉. Acesso em: 28 abr. 2003. 
BERBEROGLU, S. et al. The integration of spectral and textural information using neural networks for land cover mapping in the mediterranean. Computers $\&$ Geosciences, v. 26, n. 4, p. 385-396, May, 2000. Disponível em: <http://e5500.fapesp.br/pdflinks/03032819360413951.pdf>. Acesso em: 28 abr. 2003.

BERNARDES, A. Desmetropolização. Ministério das Relações Exteriores. Disponível em: <http://www.mre.gov.br/cdbrasil/itamaraty/web/port/consnac/ocupa/procurb/desmet/ index.htm>. Acesso em: 18 jun. 2003.

CAMPOS, M. A. A. Incorporação de dados auxiliares no processo de classificação. Disponível em <http://www.geoc.ufpr.br/ gfoto/pdi/dadosaux/dadosaux.html>. Acesso em: 16 nov. 2002.

CAPOBIANCO, J. P.; WHATELY, M. Billings 2000. Ameaças e perspectivas para o maior reservatório de água da região Metropolitana de São Paulo. São Paulo: Instituto Socioambiental, Mar. 2002. 60p. Disponível em: <http://www.camaradecultura.org/billings2000.pdf> . Acesso em: 28 abr. 2003.

EASTMAN, J. R., IDRISI for Windows: Manual do usuário. Introdução e Exercícios tutoriais. Trad. de Heinrich Hasenack e Eliseu Webwe. Porto Alegre: UFRGS/ Centro de Recursos Idrisi, 1998. 245p. Disponível em: 〈http://www.ecologia.ufrgs.br/idrisi/download/tutorial.pdf $>$. Acesso em: 28 jan. de 2000.

EMPLASA - Empresa Paulista de Planejamento Metropolitano S.A. Taxa geométrica de crescimento anula da população residente: 1996/2000. Disponível em

<http://www.emplasa.sp.gov.br/estatistica_teste/dados/Grafico/demograf/Gv005.jpg >. Acesso em: 19 out. 2002a.

Evolução da População Residente: 1970-1980-1991-2000.

Disponível em: 
<http://www.emplasa.sp.gov.br/estatistica_teste/dados/DEMO/tabela/tabelaV_9.htm

>. Acesso em: 17 nov. $2002 b$

Taxa geométrica de crescimento anual da população residente.

Disponível em:

〈http://www.emplasa.sp.gov.br/estatistica_teste/dados/Grafico/demograf/Gv003.jpg >.Acesso em: 20 out. 2002c.

Consórcio Intermunicipal das Bacias do Alto Tamanduateí e

Billings - Grande ABC. Disponível em:

$<$ http://www.emplasa.sp.gov.br/perfilgsp/ie/municipios/default.asp $>$. Acesso em: 17 nov. 2002d.

As regiões metropolitanas do Brasil. Disponível em:< http://www.emplasa.sp.gov.br/>. Acesso em: 18 jun. 2003.

FOODY, G.M. Estimation of sub-pixel land cover composition in the presence of untrained classes. Computers \& Geosciences, v. 26, n. 4, p. 469-478, May, 2000. Disponível em: <http://e5500.fapesp.br/pdflinks/03032810150325643.pdf〉. Acesso em: 28 abr. 2003.

FOODY,G. M.; ARORA, M. K. Incorporating mixed pixels in the training, allocation and testing stages of supervised classifications. Pattern Recognition Letters, v. 17, n. 13, p.1389-1398, Nov., 1996. Disponível em: $<$ http://e5500.fapesp.br/pdflinks/03032810280926195.pdf $>$. Acesso em: 28 abr. 2003.

FRANKLIN, S.E.; WULDER, M. A.; LAVIGNE, M.B. Automated derivation of geographic window sizes for use in remote sensing digital image texture analysis. Computers \& Geosciences, v. 22, n. 6, p 665-673, July, 1996. Disponível em: <http://e5500.fapesp.br/pdflinks/03032810354626608.pdf>. Acesso em: 28 abr. de 2003. 
HAACK, B.; BECHDOL, M. Multisensor remote sensing for land use/cover mapping. Computers, Environment and Urban Systems, v. 23, n. 1, p. 53-69, Jan., $1999 . \quad$ Disponível em: <http://e5500.fapesp.br/pdflinks/03032810385026777.pdf>. Acesso em: 28 abr. 2003.

IMAGERY CENTRAL. Satellite Imagery Sensors. Quick Bird. Disponível em: $\langle\underline{\text { http://www.sdcsc.com/imagery-central/files/sensors.asp?sensornum=2> }}$.

Acesso em: 6 abr. 2003.

INPE. Instituto Nacional de Pesquisas Espaciais. O satélite LANDSAT. Disponível em:

<http://www.dgi.inpe.br/html/landsat.htm>. Acesso em: 20 jan. 2001.

SPRING, Tutorial de Geoprocessamento. Classificação. Disponível em : <http://www.dpi.inpe.br/spring/teoria/classif/classif.htm>. Acesso em: 3 abr. 2002.

JARVIS, C. H.; STUART, N. The sensitivity of a neural network for classifying remotely sensed imagery. Computers \& Geosciences, v.22, n. 9, p. 959-967, Nov., 1996. Disponível em: <http://e5500.fapesp.br/pdflinks/03032813564603230.pdf>. Acesso em: 28 abr. 2003.

LANDSAT 7. O ponto de vista definitivo. Disponível em: <http://www.landsat.com.br/>. Acesso em: 11 abr. 2003.

LO, C. P. Application of LANDSAT TM data for quality of life assessment in an urban environment. Computer, Environment and Urban Systems, v.21, n. 3-4, p. 259-276, May, $1997 . \quad$ Disponível em: <http://e5500.fapesp.br/pdflinks/03032818580613357.pdf>. Acesso em: 28 abr. 2003.

MASSER, I. Managing our future: the role of remote sensing and geographic information systems. Habitat International, v. 25, n. 4, p. 503-512, Dec., 2001. Disponível em: <http://e5500.fapesp.br/pdflinks/03032819154013672.pdf>. Acesso em: 28 abr. 2003. 
MATTIKALLI, N.M. Soil color modeling for the visible and near-infrared bands of LANDSAT sensors using laboratory spectral measurements. Remote Sensing of Environment, v. 59, n. 1, p.14-28, Jan., 1997. Disponível em: <http://e5500.fapesp.br/pdflinks/03032819115513617.pdf>. Acesso em: 28 abr. 2003.

MOLLER-JENSEN, L. Classification of urban land cover based on expert systems, object models and texture. Computers, Environment and Urban Systems, v. 21, n. 3-4, p. 291-302, May, $1997 . \quad$ Disponível em: <http://e5500.fapesp.br/pdflinks/03032819251113809.pdf>. Acesso em: 28 abr. 2003.

MUNICÍPIO DE SÃO BERNARDO DO CAMPO. Evolução da população.

Disponível

em:

<http://www.saobernardo.sp.gov.br/sec_administracao/evolucaopopulacao.htm.>

Acesso em: 16 out. 2002.

NASA -LANDSAT 7 . Science Data Users Handbook. Disponível em: <http://tpwww.gsfc.nasa.gov/IAS/handbook/handbook_htmls/chapter6/chapter6.htm 1>. Acesso em: 29 ago. 2001a

\section{LANDSAT 7.}

Disponível em: <http://geo.arc.nasa.gov/sge/landsat/l7.html>. Acesso em: 28 ago. $2001 b$

NISHIDA, W. Uma rede neural artificial para classificação de imagens multiespectrais de sensoriamento remoto. Florianópolis, 1998. Dissertação (mestrado). Departamento de Engenharia de Produção, Universidade Federal de Santa Catarina. Disponível em: <http://www.eps.ufsc.br/disserta98/waleska/>. Acesso em: 27 ago. 2002.

NOAA - National Oceanic and Atmosferic Administration. Glossary. Disponível em: <http://www.srrb.noaa.gov/highlights/sunrise/spectrum.gif >. Acesso em: 29 abr. 2003. 
OLMO, M, C; HERNANDEZ, F. A. Computing geostatistical image texture for remotely sensed data classification. Computers \& Geosciences. v. 26, n. 4, p. 373383, May, 2000. Disponível em: <http://e5500.fapesp.br/pdflinks/03032819285913872.pdf>. Acesso em: 28 abr. 2003.

QUATTROCHI, D.A.; RIDD, M.K. Analysis of vegetation within a semi-arid urban environment using High Spatial Resolution Airborne Thermal Infrared remote sensing data. Atmospheric Environment, v. 32, n. 1, p. 19-33, Jan., 1998. Disponível em: <http://e5500.fapesp.br/pdflinks/03022419164912289.pdf>. Acesso em: 24 mar. 2003.

SCHOWENGERDT, R.A. On the estimation of spatial-spectral mixing with classifier likelihood functions. Pattern Recognition Letters, v. 17, n. 13, p. 13791387, Nov., $1996 . \quad$ Disponível em: <http://e5500.fapesp.br/pdflinks/03022417273809524.pdf>. Acesso em: 24 mar. 2003.

SERPICO, S. B.; BRUZZONE, L.; ROLI, F. An experimental comparison of neural and statistical non-parametric algoritms for supervised classification of remote sensing images. Pattern Recognition Letters, v. 17, n. 13, p. 1331-1341, Nov., 1996. Disponível em: <http://e5500.fapesp.br/pdflinks/03022417123108917.pdf>. Acesso em: 24 mar. 2003.

STATSOFT, INC. Statistic Homepage. Neural Networks. Disponível em: <http://www.statsoft.com/textbook/stneunet.html\#intro>. Acesso em: 17 ago. 2002.

STATE OF OREGON. Oregon administrative rules 1998 complation - land conservation and development department division 21: urban reserve areas. Oregon Secretary of State, 14 nov. 1997. Disponível em: <http://www.teleport.com/ ohen/oradmin.html>. Acesso em: 17 ago. 2002.

STAMPLETON, R.M. Protection the source: how land conservation safeguards drinking water. TPL report, 1997, The Trust for Public Land, 1998. (Executive 
Summary,

Introduction).

Disponível

em:

<http://www.tpl.prg/tpl/newsroom/reports/ptsource.html> Acesso em: 20 ago. 2002.

STEELE, B. M. Combining multiple classifiers: an application using spatial and remotely sensed information for land cover type mapping. Remote Sensing of Environment, v. 74, n. 3, p. 545-556, Dec., 2000. Disponível em: <http://e5500.fapesp.br/pdflinks/03022416083005765.pdf>. Acesso em: 2 dez. de 2000.

STEFANOV, W. L.; RAMSEY, M.S.; CHRISTENSEN, P. R. Monitoring urban land cover change: na expert system approach to land cover classification of semiarid urban centers. Remote Sensing of Environment. v. 77, n. 2, p. 173-185, Aug., 2001. Disponível em: <http://e5500.fapesp.br/pdflinks/03022417075008669.pdf>. Acesso em: 24 mar. 2003.

STUCKENS, J.; COPPIN, P. R.; BAUER, M. E. Integrating contextual information with per-pixel classification for improved land cover classification. Remote Sensing of Environment. v. 71, n. 3, p. 282-296, Mar., 2000. Disponível em: <http://e5500.fapesp.br/pdflinks/03022417035308453.pdf>. Acesso em: 24 mar. 2003.

USGS/EROS Data Center LANDSAT 7 Website. LANDSAT program. Disponível em: <http://landsat7.usgs.gov/faq.html>. Acesso em: 20 nov. 2001.

YUAN, Y.; RICHARD M. S.; LIMP. W. F. Remodeling census population with spatial information from LANDSAT TM Imagery. Computers, Environment and Urban Systems. v. 21, n. 3-4, p. 245-258, May, 1997. Disponível em: $<$ http://e5500.fapesp.br/pdflinks/03022416261106824.pdf>. Acesso em: 24 mar. 2003.

ZHANG, Y. Optimisation of building detection in satellite images by combining multispectral classification and texture filtering. ISPRS Journal of Photogrammetry \& Remote Sensing, v. 54, n. 1, p. 50-60, Feb., 1999. Disponível em : <http://e5500.fapesp.br/pdflinks/03022416145706153.pdf>. Acesso em: 24 mar. 2003. 